\section{The Persistence and Characteristics of Chinook Salmon Migrations to the Upper Klamath River Prior to Exclusion by Dams}

\author{
John B. Hamilton, Dennis W. Rondorf, \\ William R. Tinniswood, Ryan J. Leary, \\ Tim Mayer, Charleen Gavette, and \\ Lynne A. Casal
}

FOR THOUSANDS OF YEARS, the Klamath (or Ewksiknii), Modoc, and Yahooskin band of Snake Indians - joined today as the Klamath Tribes have inhabited the upstream portion of the Klamath River watershed, now part of Oregon. Early accounts by non-Indians visiting the area describe the Native people as primarily dependent on fishing, rather than hunting. ${ }^{1}$ The Columbia River and the Klamath River, with its vast watershed covering 40,790 square kilometers, provide the only Pacific salmon habitat east of the Cascade mountain range in the United States. The harvest and the migration of ocean-going salmon in the Klamath River are prominent in Tribal culture and oral history. ${ }^{2}$

The following Indian legend about the Klamath River seems especially relevant today, as various interests are working to restore salmon migrations:

The Coyote went at length on his tour of inspection to the country of the Klamath river and found the people there in the most destitute condition. The river had had an abundance of salmon, but three Skookums [someone powerful or possibly a monster] at the mouth of the stream had constructed a dam so that they might get all the fish, and thus prevented the ascent of the customary food supply. By this selfishness of the Skookums he was much incensed and vowed that before many days so much fish should come up the river as to give all the men, women, and children, and even the dogs, all the food they could

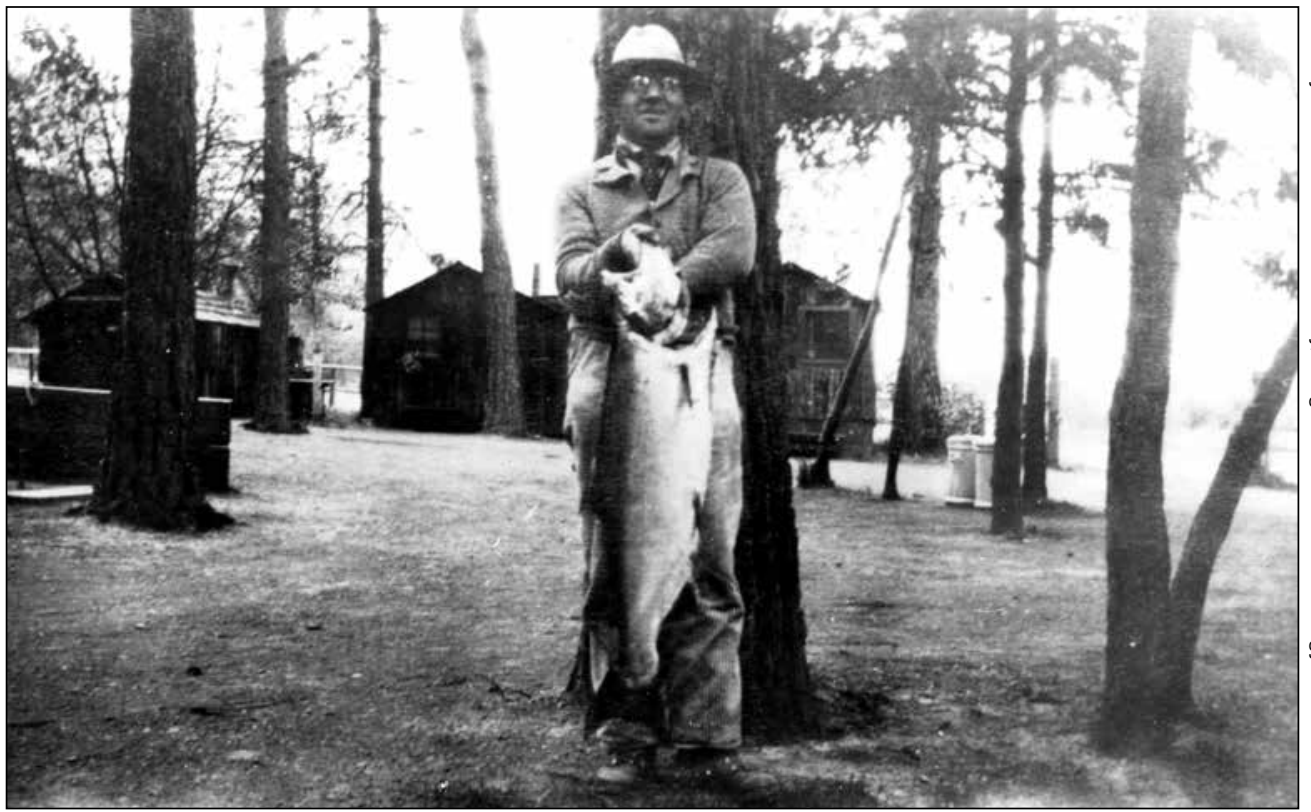

IN THIS PHOTOGRAPH, a Native American holds a twenty-five-pound salmon likely caught just upstream from the Link River Bridge. According to new information found following the authors' 2005 report, salmon returning to the Klamath Upper Basin in the 1890 s and early 1900 s ranged from 4.5 to 35 kilograms (ten to eighty pounds), with an average of greater than twenty pounds.

eat. He went to the mouth of the river and found the house of the Skookums, and entering as a homeless coyote began his observations. Although he was hungry and whined for some of the fine fish that the Skookums had, he was not noticed, and his fast was unbroken, even with the smell of delicious salmon in his nostrils. He saw, however, where the Skookums kept their key for the gate of the dam, and the next morning, when one of the three women started down to open the trap and let out a fish for herself, he darted out of the lodge and running between her feet succeeded in tripping her, so that she fell and threw the key out of her hand. Seizing this instantly the Coyote went to the dam and opened the gate, letting the swarming salmon pass through, and up to the country of the Cahroes. He then broke down the dam and since that time the fish have gone every year to the upper stream. ${ }^{3}$

This legend is attributed to the Karuk (Cahroe) Tribe, but similar legends exist in the Klamath Tribes' oral history in Oregon. ${ }^{4}$ The story of the three Skookums illustrates the importance of unimpeded salmon migration throughout the Klamath River. We examined the history of salmon distribution in habitat 
upstream from the current hydroelectric dams on the Klamath River in a publication by the lead author of this article and several co-authors in 2005. Since that synthesis, we have found extensive new information. ${ }^{5}$ Some of that newly considered information brings into question the previous conclusion that Chinook salmon migrated historically to the Klamath Upper Basin and has prompted further examination of the record. ${ }^{6}$ The new examination and analysis also allowed us to address some of the lingering questions regarding the role Klamath dams played in the decline of salmon migrations and the historical abundance of migrations upstream from the dams. Finally, this new synthesis also resolves the mystery of when historical migrations ceased and helps clarify the role of various impacts on Chinook salmon migrations upstream from Iron Gate Dam (IGD).

Many consider the three California dams on the Klamath River (Iron Gate and Copco 1 and 2) to be today's three Skookums, as they have excluded ocean-going salmon from migration to hundreds of kilometers of habitat upstream from IGD. At one time, Klamath River salmon migrations were the third-largest on the West Coast. Migrations have supported famous salmon recreational fisheries, ocean commercial fisheries, and a large in-river commercial fishery, which in turn supported several canneries near the mouth of the river. ${ }^{7}$ More recently, a limited ocean commercial fishery has continued but, in years when low returns are forecast, has been severely restricted in order to protect Klamath River stocks. ${ }^{8}$ In addition to the Klamath Tribes, there are five federally recognized tribes downstream in the Klamath River watershed as well as the unrecognized Shasta Tribe, all of which have a tradition of salmon fishing. ${ }^{9}$ The Yurok and Hoopa Valley Tribes, in the lower river, have federally reserved fishing rights. All of these fisheries would benefit from Chinook salmon that originated from historical habitat upstream from dams on the Klamath River.

Stakeholders signed an amended Klamath Hydroelectric Settlement Agreement in April 2016 that asked the Federal Energy Regulatory Commission (FERC) to order the decommissioning of the lower four dams on the Klamath River and restore salmon migration to their historical habitat. Alternatively, should the settlement agreement collapse and FERC relicense the dams, fishways (passageways over or through dams) would be required. Regardless of whether fishways are constructed or dams are removed, there is widespread interest in restoring salmon and other anadromous fish to the habitats that once supported them upstream from the dams on the Klamath River. The State of Oregon and the Klamath Tribes have taken initial steps toward planning reintroduction. ${ }^{10}$ More detailed plans to reintroduce Chinook salmon into their historical habitats upstream from IGD will be developed in the near future. Those plans will be informed by understanding the characteristics of historical migrations, and we therefore offer here our analysis and conclusions.

In 1846, at what was to become Linkville and is now known as Klamath Falls, Oregon, western explorer John C. Frémont recorded that his party obtained salmon from one of the Indians, a chief. He thereby became the first known non-Indian to report salmon at the outlet of Upper Klamath Lake." Over the past century and a half, anadromous fish migrations have ceased entirely to reach the location where Frémont traded with the Klamaths for salmon, and in the Klamath River as a whole, migrations have declined dramatically. It is estimated that Klamath River migrations of fall- and spring-run Chinook salmon have been reduced by over 90 percent from those in the early twentieth century.12 Managers have attributed the losses to hydraulic mining, overfishing, intensive water diversions, erosion caused by numerous roads, extensive logging, floods, and catastrophic forest fires. ${ }^{13}$

The principle years for the drastic habitat alterations associated with mining were 1850 to 1865 . Hydraulic mining continued until 1884 , when it was outlawed by a federal court, but hydraulic-mined gold fields show the lasting effects of destructive mining well over a century later. ${ }^{14}$ As author Joaquin Miller put it in 1873: "The miners have filled its bed with tailings from sluice and tom; they have dumped, and dyked, and mined in this beautifu river-bed till it flows sullen and turbid enough."15 Overfishing also took a toll on the salmon migrations. A vigorous lower-river commercial fishery followed hydraulic mining in 1876, with its historical peak occurring in 1912 and the closure of its canneries, due to overfishing, in $1933 .{ }^{16}$ The building of dams and resulting blockage of salmon migration to the upper portion of the watershed certainly contributed to the losses, although many have questioned the extent to which dams damaged Klamath River migrations. ${ }^{17}$ In particular, in 1931, John O. Snyder attributed the loss of early, or spring-run, salmon to other impacts. He concluded that "the depletion of the early run was well under way, if not about complete long before the erection of the dam [the first hydroelectric dam on the Klamath River]." ${ }^{18}$ As our information and analysis show, early migrations were not depleted as early as Snyder concluded.

Today, declines in the migrations of Klamath River Chinook salmon have widespread impact on ocean commercial, Tribal, and sport fisheries. To ameliorate these losses, Public Law 99-552 (known as the Klamath Act) was signed by President Ronald Reagan in 1986 to authorize the federalstate cooperative, Klamath River Basin Conservation Area Restoration Program, tasked with rebuilding the river's fish resources. The act created 
a sixteen-member Klamath River Basin Fisheries Task Force made up of representatives from Tribes, counties, federal and state agencies, and fishing organizations. It directed the Secretary of the Department of the Interior to cooperate with the task force in creating a long-range plan for restoration. In its plan, the task force identified access to habitat upstream from dams as an objective for restoring anadromous fish populations. ${ }^{19}$

One way to provide access to historical habitat is through fishways, including both fish ladders for upstream passage and screens that allow juvenile salmon to migrate safely downstream. The practice of using fishways as a vehicle for maintaining a public-trust resource is a principle rooted in English common law. ${ }^{20}$ The modern-day manifestation of this precedent, as it relates to hydropower projects, is Section 18 of the Federal Power Act. To provide for the public trust, the Departments of Commerce and the Interior have mandatory authority to prescribe fishways during the licensing and relicensing of hydropower dams by FERC under Section 18. Licenses for dams are typically issued for thirty to fifty years. While the Departments of the Interior and Commerce use this authority judiciously, the record of historical fish migrations upstream from Klamath River dams, and their importance to fisheries on the Klamath River, warranted mandatory fishway prescriptions in 2007

\section{THE HISTORICAL PRESENCE OF CHINOOK SALMON UPSTREAM}

\section{FROM IRON GATE DAM}

Frémont traded for his salmon at the outlet of Upper Klamath Lake, from which a short waterway, referred to as Link River, flows to Lake Ewauna. Link River is entirely within the city limits of today's Klamath Falls, Oregon. From Lake Ewauna downstream to the Pacific Ocean, the waterway is referred to as the Klamath River. In this article, we refer to historical habitat of Chinook salmon in two reaches: the complete river system upstream from the current location of IGD, which we refer to as "upstream from IGD," and the portion of the river system within that section but only upstream from and including Link River, which we refer to as the "Klamath Upper Basin." We have identified the locations of current dams on the map on the facing page from downstream to upstream: Iron Gate (river kilometer, or RK, 306, completed in 1962), Copco 2 (RK 319.5, completed in 1925), Copco 1 (RK 320, completed in 1918), J.C. Boyle (RK 362, completed in 1958), Keno (RK 375, replaced in 1967), and Link River (RK 410, completed in 1921). Of these dams, only Link River is within what we refer to as the Klamath Upper Basin.

While the record indicates that Chinook salmon were historically present upstream from IGD but also within the Klamath Upper Basin, there continues

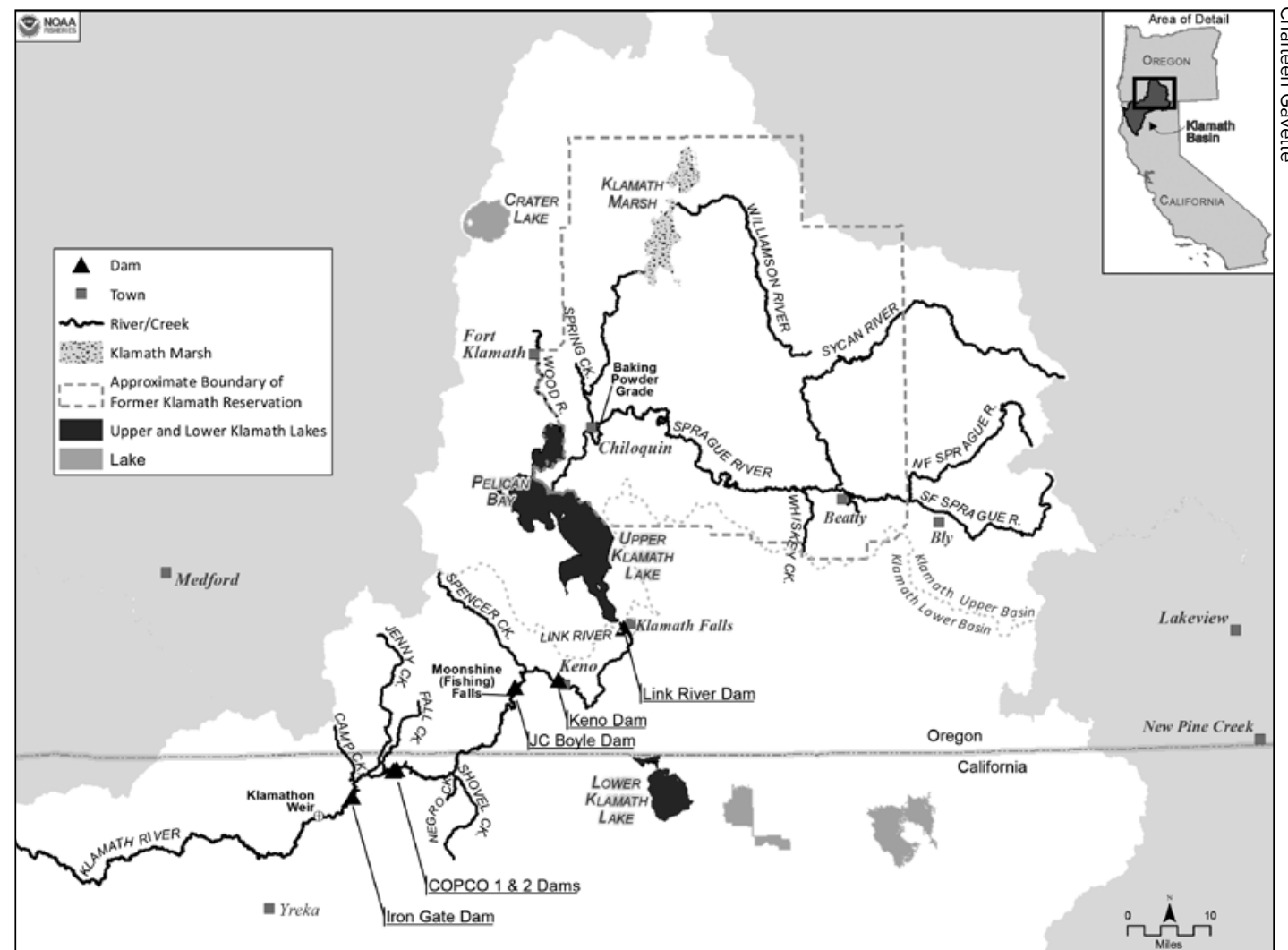

THIS MAP DETAILS part of the Klamath watershed in California and Oregon, showing dams (triangles) and Chinook salmon observation locations. The Link River and upstream are considered the Klamath Upper Basin.

to be skepticism from some parties regarding this conclusion. In particular, some have questioned whether early non-Native explorers of the region may have misidentified other fish as Chinook salmon in the Klamath Rive upstream from IGD. The presence and the correct identification of salmon were, however, particularly important guides for early explorers of western North America. As noted by Meriwether Lewis and William Clark in their 1804-1806 Expedition, for example, the presence of salmon confirmed that their location, a tributary of the Columbia River, was connected to the Pacific Ocean. ${ }^{21}$ The presence of salmon on the Klamath River in 1827 also confirmed for fur trader Peter Skene Ogden that he was on a waterway that discharged to the ocean. ${ }^{22} \mathrm{At}$ the Link River portion of the waterway, Frémont also saw salmon as a signpost that the "Tlamath" [Klamath] River was connected to 
the ocean: "Up this river the salmon crowd in great numbers to the lake [Upper Klamath Lake], which is more than four thousand feet above the sea." ${ }^{23}$

While a later report notes that there was some uncertainty regarding distinction "by early fishermen and old residents" between one anadromous salmonid species and another, other accounts clarify that most observers could discern salmon (Oncorhynchus sp.) from steelhead (Oncorhynchus mykiss, previously Salmo gairdneri) or resident redband trout (Oncorhynchus mykiss sp.) and that details on weights of fish indicated they could only be Chinook salmon. ${ }^{24}$ Oregon fishing regulations for the Klamath River in the first part of the twentieth century, furthermore, were specific to salmon versus trout. ${ }^{25}$ The Klamath Falls Evening Herald articles indicate that salmon migration was a front-page topic and that salmon were locally distinguished from other fish species. ${ }^{26}$ Finally, Kenneth Simmons summarized extensive accounts indicating that affiants for a proposed Department of the Interior lawsuit on the behalf of the Klamath Tribes in the 1940s correctly identified Chinook salmon caught in the Klamath Upper Basin. ${ }^{27}$

In this regard, correspondence between Dr. J.C. Merrill at Fort Klamath, Oregon, and staff of the U.S. National Museum (affiliated with the Smithsonian Institution) is of especially significant value. Merrill collected and prepared a large number of specimens for the museum and referred to them by their scientific names. While he did not catalogue the specimen in the Smithsonian collection, in an October 21, 1886, memoranda, Merrill wrote to Professor G. Brown Goode at the museum that he had identified a specimen from the vicinity of Fort Klamath that could only have been a Chinook salmon. ${ }^{28}$ Finally, anatomical characteristics from historical photos in this publication clearly show that the fish were identified correctly as salmon. This information, together with the archeological and DNA studies that have identified the only salmon species in the Klamath Upper Basin as Chinook, supports our conclusion that the historical references to salmon were to Chinook salmon. ${ }^{29}$

In working to further examine the record on Chinook salmon upstream from IGD, we generally continued the methods used in Hamilton et al. (2005) to address the uncertainty in the record and summarize information useful to salmon managers. Our summaries and analyses were based on reports, photos, historical documents, newspaper articles, and other available information (see Table 1A). Since 2005, however, we have taken advantage of recently digitized historical newspapers (California State Library - California Digital Newspaper Collection; University of Oregon Library - Historic Oregon Newspaper Collection). We also reviewed additional non-digital newspaper archives and Department of the Interior documents that we did not have access to when researching the 2005 publication. We found a great deal of relevant technical information contained in affidavits prepared for the Department of the Interior lawsuit in the 1940s. ${ }^{30}$

We found no new documents indicating that salmon did not migrate upstream from IGD, but we identified over one hundred additional documents, one audio recording, and seven additional photos regarding salmon or salmon fishing upstream from IGD (see Table 1B). We also found five additional documents stating that salmon did not migrate as far as the Klamath Upper Basin. In a $1947 \mathrm{PhD}$ dissertation, G. Hewes concluded that salmon ascended only to "Copco Marsh" (location unknown but likely referring to habitat now under Copco 1 reservoir, at about RK 322). ${ }^{31}$ Ogden was informed by his Indian guide that salmon did not ascend the Klamath River past approximately the location of the current J.C. Boyle hydropower facility (RK 359). Earl Leitritz, in 1970, stated that salmon ascended the river at least to the vicinity of Spencer Creek (RK 369) but that investigations failed to show that any migrated upstream from that point. ${ }^{32}$ Leitritz believed that passage to the Sprague and Williamson rivers was questionable because of the falls on Link River. The explorer Stephen Powers indicated that salmon migrated only to the first rapids below Lowe Klamath Lake (about RK 375). ${ }^{33}$ Later, officials from the California-Oregon Power Company (COPCO) reported that salmon had never gone up the Sprague Rive "because of growth of fungus near the outlet of Klamath Lake" (RK 409). ${ }^{34}$ We found nothing in the new information to support Leitritz's that passage to the Sprague and Williamson rivers was questionable because of the falls on Link River. Quite the opposite, ethnographers Kroeber and Barrett concluded in a 1960 publication that both salmon and steelhead trout historically ran up the Klamath River "into the Klamath lakes and their tributaries," thereby correcting Kroeber's 1953 account to the contrary. ${ }^{35}$ Unlike the five accounts from Ogden, Powers, Hewes, Leitritz, and COPCO, of the over one hundred new records, we found sixty five new records indicating that Chinook salmon migrated to the Klamath Upper Basin. We also found four new historical photos and one new personal communication documenting salmon in the Klamath Upper Basin (see Table 1B).

Short of the headwater cascades or falls like those just downstream from Klamath Marsh on the Williamson River, the Klamath River had no natural permanent barriers that could have obstructed salmon from migrating upstream of IGD or to the Klamath Upper Basin. There were impediments that may have been difficult for salmon to migrate, but they were not impassable. In some cases, those impediments created concentrations of salmon that were easy to harvest. These probably included Ishi Pishi Falls (about RK 217), COPCO Canyon (about RK 321), the Caldera cascade reach (about RK 
345), Moonshine or "Fishing" Falls (about RK 381), and the falls at Link River (about RK 408). Fishery managers often proposed to negate these impediments to migration by the installation of fish ladders or to alter the channel with dynamite to make salmon migration easier. The following account from an April 1910 newspaper article offers one example, apparently to assist spring-run Chinook salmon:

Now that the salmon are beginning to make for their spawning grounds at the headwaters of the Klamath River and the lakes tributary, agitation for a fish ladder over the [Moonshine or Fishing] falls is being renewed. ${ }^{36}$

Numerous other newspaper accounts indicate it was widely understood that salmon migrated to Upper Klamath Lake and spawned in its tributaries. ${ }^{37}$

\section{THE HISTORICAL ABUNDANCE OF CHINOOK SALMON UPSTREAM} FROM IRON GATE DAM

In the new information, we found three sources that, although confirming the presence of returning salmon upstream from IGD, have brought to question the abundance of those migrations (Table 2). ${ }^{38} \mathrm{~A} 1901$ Oregon Department of Fisheries report described the Klamath run as "small." 39 Again, Hewes (1947) concluded that few salmon ascended the Klamath River and its tributaries upstream of "Copco Marsh." ${ }^{\circ 0}$ Historian Jeffrey LaLande concluded that before the first hydroelectric dam was built, only a hardy few Chinook salmon would reach Upper Klamath Lake and the Williamson River and that the major portion of the spawning migrations did not pass that far upstream; during some years, he noted, channel conditions blocked all the fish from reaching Upper Klamath Lake and the Williamson River. ${ }^{41}$ Contrary to these reports, we found many historical accounts, starting as early as Frémont's 1846 memoir, indicating that salmon migrations were abundant not only upstream from IGD but in the Klamath Upper Basin as well (see Tables 1A, 1B, and 2). Anecdotal estimates of abundance ranged from thousands to millions of salmon returning upstream from IGD. ${ }^{42}$ The numbers of returning salmon likely numbered somewhere between these two orders of magnitude. While it is prudent to use caution in making extrapolations from numbers presented in anecdotal information, these historical accounts demonstrate that there were considerable returns of anadromous fish above the current location of IGD.

One partial exception is the account by Ogden, who was a chief trader for the Hudson's Bay Company during the 1820s. A notable explorer of the American West, he was the first non-Indian to visit and write about Klamath Marsh, Upper Klamath Lake, and Native groups in what would become southern Oregon and northern California. ${ }^{43} \mathrm{His}$ expedition's relations with the Klamath and Modoc were positive, and his journals provide the first ethnographic accounts of their cultures. In December 1826, he and his brigade arrived in Klamath Indian territory from the high desert and the uppe Deschutes country. Nearing starvation, they were keen to trade for food, and his party was able to obtain "40 dogs and some small fish not more than two inches in length." Later, on the east side of Upper Klamath Lake, his party traded for more dogs, roots, and "20 fine Carp." ${ }^{44}$ But other than noting salmon ascending to the approximate location of the current John $\mathrm{C}$. Boyle facility, Ogden made no mention of trading for salmon while among the Klamath Indians of the Williamson River and Upper Klamath Lake area, nor does he mention seeing any salmon in their villages..$^{45}$

Clearly, given Klamath Indian oral history and the archeological identification of Chinook salmon bones going back as far as 5,000 years, this species was present in the Klamath Upper Basin long before Ogden's account. ${ }^{46}$ Yet, if salmon did not ascend upstream past this location, as Ogden concluded in 1826, their migration may have been temporarily blocked by natural events. The Klamath River canyon in the vicinity of what is currently the J.C. Boyle facility is known as a potential landslide and rock fall area. ${ }^{77} \mathrm{It}$ is quite possible, if Ogden's account and LaLande's conclusions are correct, that migration was occasionally interrupted by those natural events.

We found one historical impediment to migration due to human activity. Klamathon Dam, a log-crib dam 1.5 to 2 meters high, constructed in 1889 by a timber company for its mill at Klamathon, California, temporarily blocked migrations during the fall of that year. Klamathon Dam blocked significant numbers of late-run salmon attempting to return to hundreds of kilometers of habitat upstream. It is notable that FERC later determined that the majority of the salmon that passed Klamathon also migrated further upstream, past where IGD now stands. ${ }^{48}$ When first constructed, Klamathon Dam lacked fish passage, and many salmon either died downstream or ended up captured in boxes placed strategically on the lower face of the dam. ${ }^{49}$ The illegally captured salmon were sold commercially. In September 1889, fifteen to twenty people were employed night and day taking large quantities of these salmon for sale and destroying thousands of others..$^{50}$ Most residents were appalled:

The catching and killing of salmon in the vicinity of Klamath City [variously called Klamathon, Manistee, or Pokegema] by the wagon load, makes the people along the river disgusted and hope that the Fish Commissioner will see that such is stopped. Aside from the wholesale slaughter, the dead fish create a nauseating stench, and are eaten by hogs along the stream, to afford pork and bacon unfit for market. ${ }^{5}$

This destruction of salmon bound for Oregon created a regional political issue and became the first precedent for fish ladders on the Klamath River. 


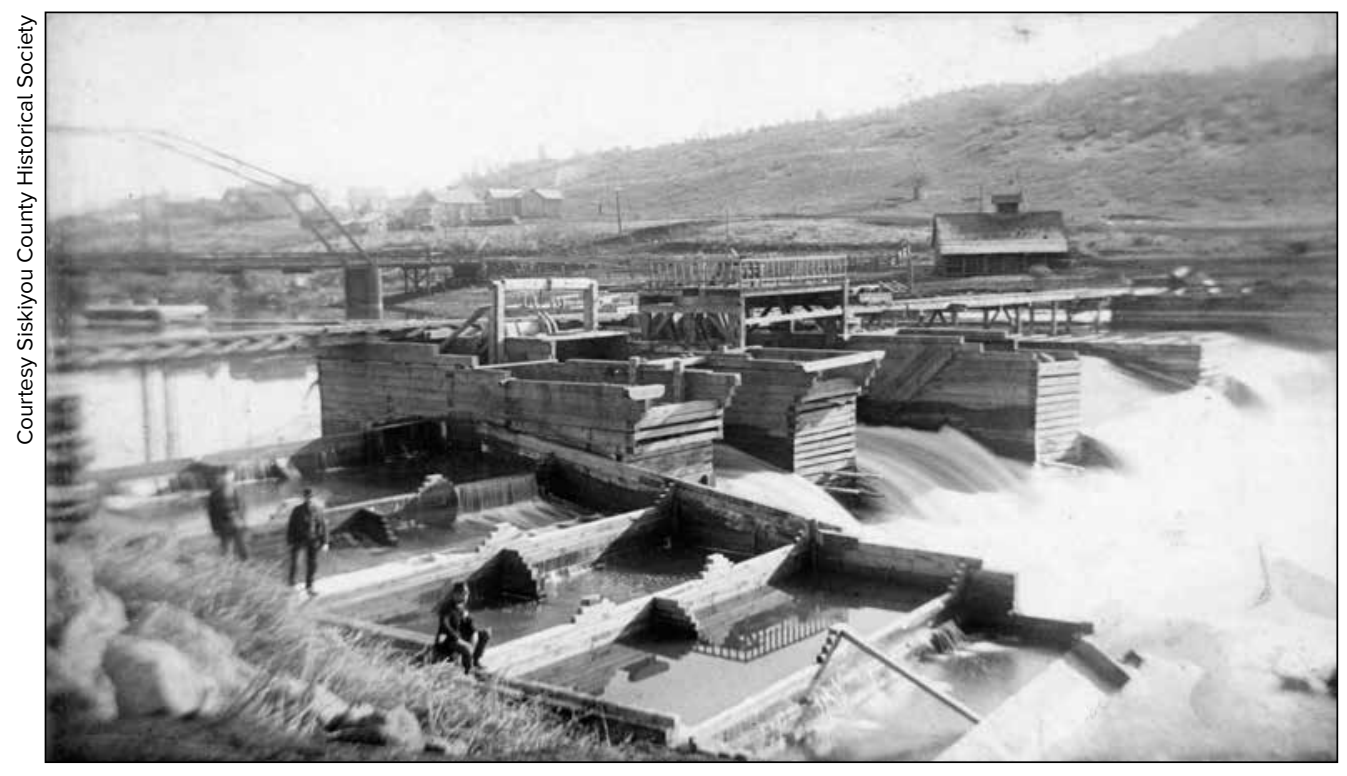

THE REBUILT KLAMATHON MILL log-crib dam and fish ladder is pictured here in 1892. The original 1889 dam did not provide a path for fish passage, and many salmon died downstream or were captured and illeglally sold.

From Salem, Oregon Governor Sylvester Pennoyer insisted that "measures be taken to stop the lawless acts and to have a fishway constructed that will allow the millions of salmon to pass up this important river, as this is the season they must go up to spawn." Governor Robert Waterman of California responded by dispatching the Deputy Fish Commissioner of California to investigate. ${ }^{22}$ Within two weeks, Waterman had appointed a Siskiyou County representative, and the matter was brought to the State Fish Commissioners. ${ }^{53}$ The Sheriff of Siskiyou County was instructed by telegraph to lend "every assistance possible" to the new Fish Commissioner. Authorities arrested seven violators. ${ }^{54}$ Although the timber company complied with the law by immediately constructing a fish ladder to pass salmon, a portion of the dam was destroyed by high flows during the following winter of 1889-1890 and, as one newspaper put it, salmon again had "free run up the Klamath River this season, clear into the lakes at its head." 55

The rebuilt, 1892 version of the ladder and the Klamathon Dam is shown above. The company maintained this ladder for fish migration in 1892, 1893, and 1897, and salmon migration resumed after 1889 (see the accounts in Table 2). ${ }^{56}$ Because its initial operation without a fish ladder was during the fall, when flows were low and passage was difficult, Klamathon Dam may have been more consequential for some seasonal migrations, such as fall-run Chinook salmon. A report from a visitor in early September 1902 indicates that migration had been fully re-established by then:

On our arrival at the springs [Klamath Hot Springs Resort at Shovel Creek (about RK 366)] we heard the good news that the rainbows were running in the river and also that a great number of salmon were making their regular fall pilgrimage to the spawning grounds, thanks to the fish ladder at Klamathon which this year was in good condition. It is the earnest wish of all those living along the Klamath, as well as of all visiting sportsmen, that this ladder be at all times kept in first class condition. ${ }^{57}$

Later that fall, on October 14, 1902, a catastrophic fire destroyed the mill, apparently including the log-crib dam, and most of the town of Klamathon..$^{58}$ The Klamathon Dam's occasional interference with salmon migration from 1890 was over. As shown in Table 2, we found the annual abundance of salmon nearly continuous after 1901. Migrations to the Klamath Upper Basin may have strengthened in the absence of the Klamathon Dam. In 1910 and 1911, newspapers reported that a recently organized Klamath County Rod and Gun Club argued that salmon were abundant, but that local fishermen were unable to catch them:

Thousands of salmon enter the Klamath River [in Oregon]... The Klamath County Rod and Gun Club desires a special provision lifting the protection from salmon to permit Klamath people to get at least some benefit from the large salmon runs here during the Fall and Spring months. Now no one is allowed to fish other than with hook and line, and as salmon will not bite a hook this law gives people here absolutely no benefit from the millions of salmon in these waters. ${ }^{59}$

The club lobbied for special legislation for Klamath County to allow the use of the grab hook (gaff), a method of harvest illegal in Oregon, for recreational salmon harvest in the Klamath Upper Basin. Rather than championing this cause, Oregon State Senator George Merryman, representing Klamath Falls, requested that the bag limit be increased from two to five salmon per day. ${ }^{60}$

These two issues again draw on anecdotal accounts to reveal considerable returns of salmon to the Klamath Upper Basin. Two years before the club's appeal, in late September 1908, the Klamath Evening Herald had reported "millions of salmon" in the Keno vicinity. ${ }^{61}$ With the club's anec- 


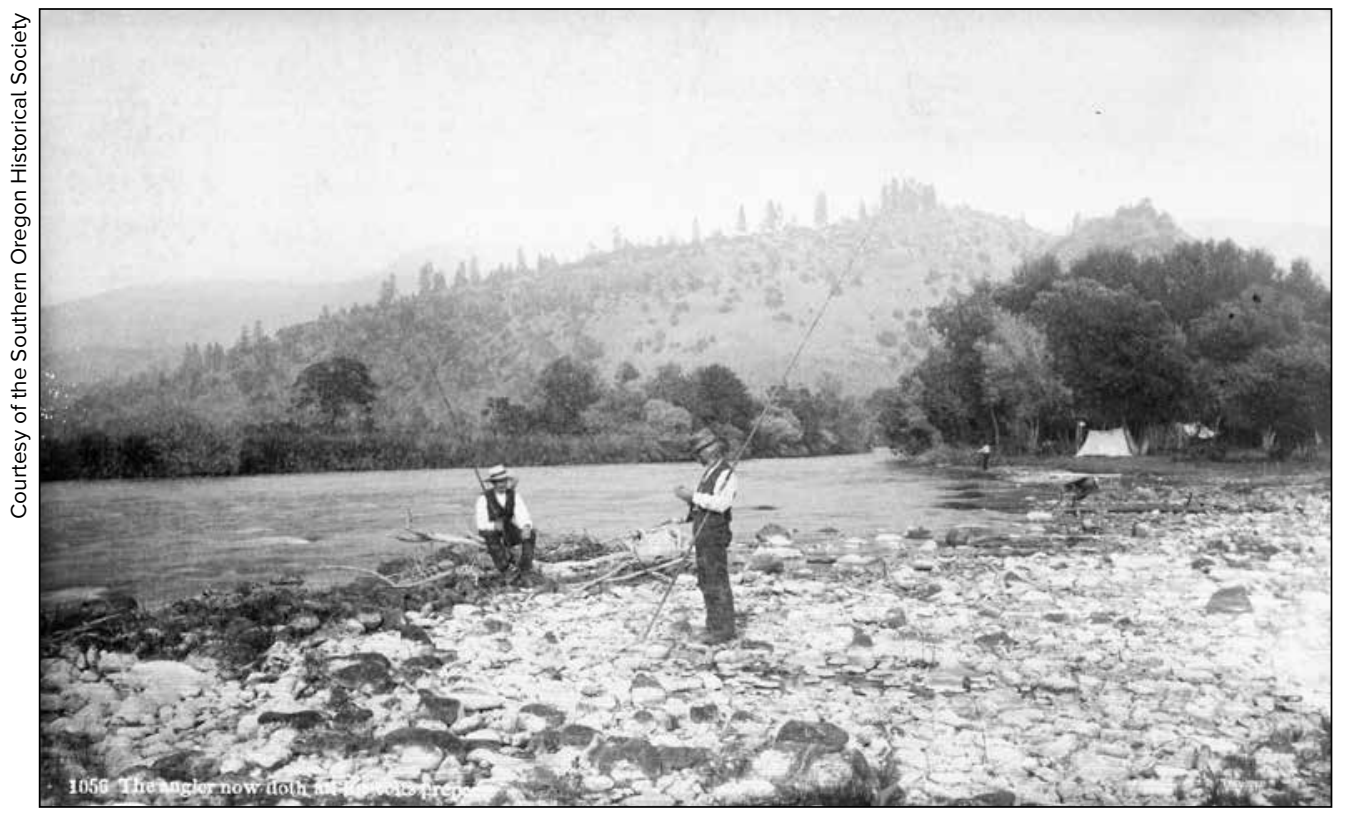

PHOTOGRAPHER PETER BRITT created this 1885 postcard showing his son Emil at the mouth of Shovel Creek near the Klamath Hot Springs Resort. One of the resort's main attractions was fishing for migratory trout and salmon in the creek and Klamath River.

dotal estimates of thousands to millions of salmon returning to Oregon in 1910, the two reports are, at the high end, consistent with Pennoyer's claim that millions of salmon returned to Oregon prior to the construction of Klamathon Dam.

\section{UPPER KLAMATH RIVER CHINOOK SALMON HARVEST AND FISHING}

\section{LOCATIONS}

Long after Frémont's 1846 account, sources document Tribal harvest of Chinook salmon at numerous locations upstream from IGD. ${ }^{62}$ New settlers in the region also relied on salmon for food and commerce. Including the Link River location where Frémont traded, we found four general areas upstream from IGD where salmon fishing was substantial enough to be associated with small-scale commercial harvest (see map on page 331). ${ }^{63}$ Some markets for harvested salmon were located out of the watershed or across the state line.

At the furthest downstream area, small-scale commercial salmon harvest took place at Shovel Creek and its tributary, Negro Creek (RK 328), near Bes- wick, California. During the California gold rush, African American families living in Yreka, California, would camp along the waterway when salmon were spawning, fish until their wagons were filled to capacity, and then take the fish into Yreka for sale to miners. ${ }^{64}$ The Klamath (also called Beswick) Hot Springs Resort was established at the mouth of Shovel Creek in the 1880s. Among its major attractions was blue-ribbon fishing for migratory trout and salmon in Shovel Creek and the nearby Klamath River. ${ }^{65}$ Perhaps as a promotion for the resort, famed photographer Peter Britt from Jacksonville, Oregon, created a postcard, featuring his son Emil, fishing at the mouth of Shovel Creek in 1885 Another famous early photographer, Maud Baldwin of Klamath Falls, Oregon, also created a photo advertisement for the resort. Southern Pacific Railroad dedicated a brochure to fishing near the resort, conveniently accessed by

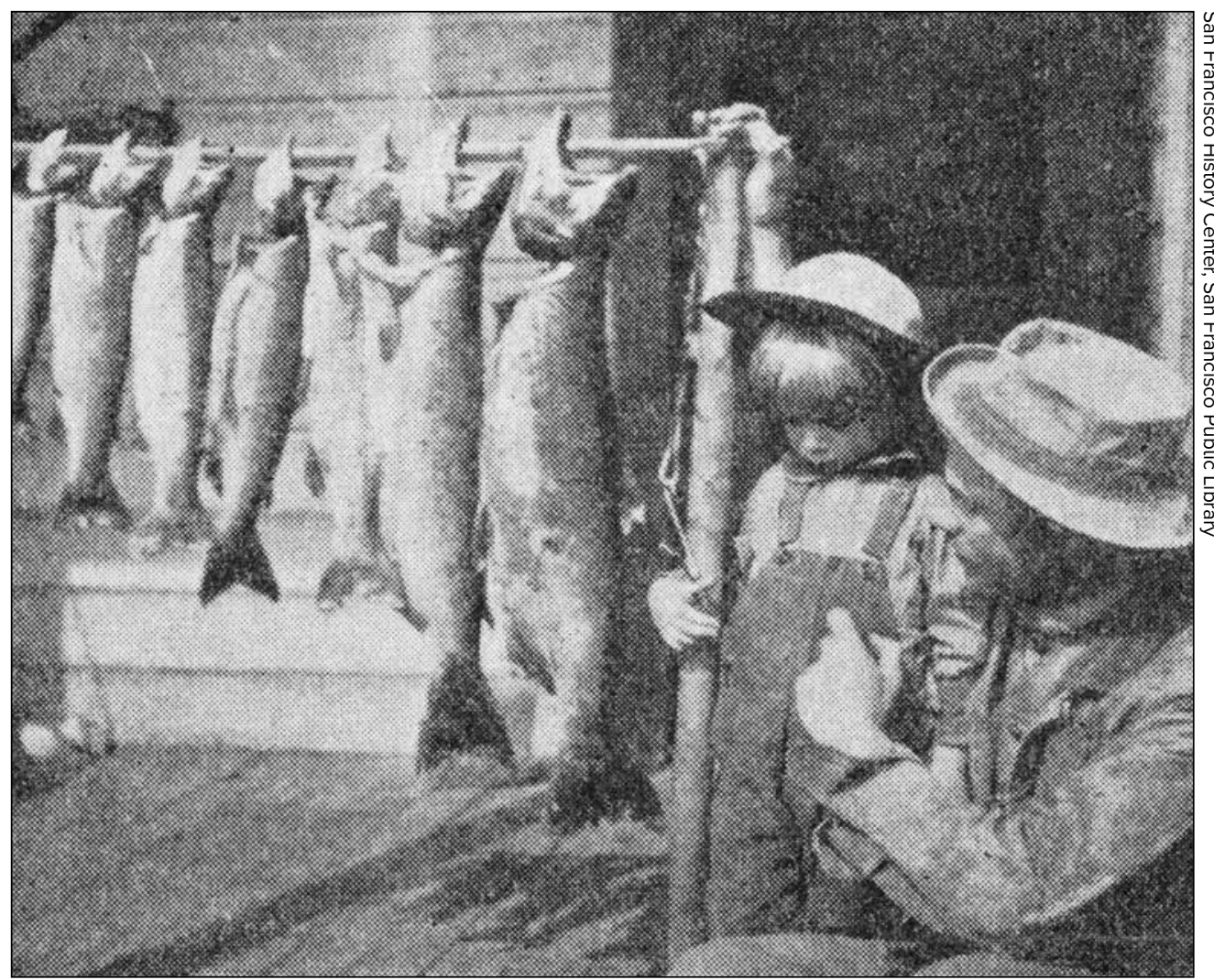

INCLUDED IN A 1902 SPREAD in Western Field magazine, this photo is titled "My Best Day's Catch" from the Klamath Hot Springs Resort. The two largest fish pictured are identified in the article as Chinook salmon (Oncorhynchus tshawytscha) weighing 8 and 10.5 lbs. Our examination of the photo confirms this identification based on anatomical characteristics. 


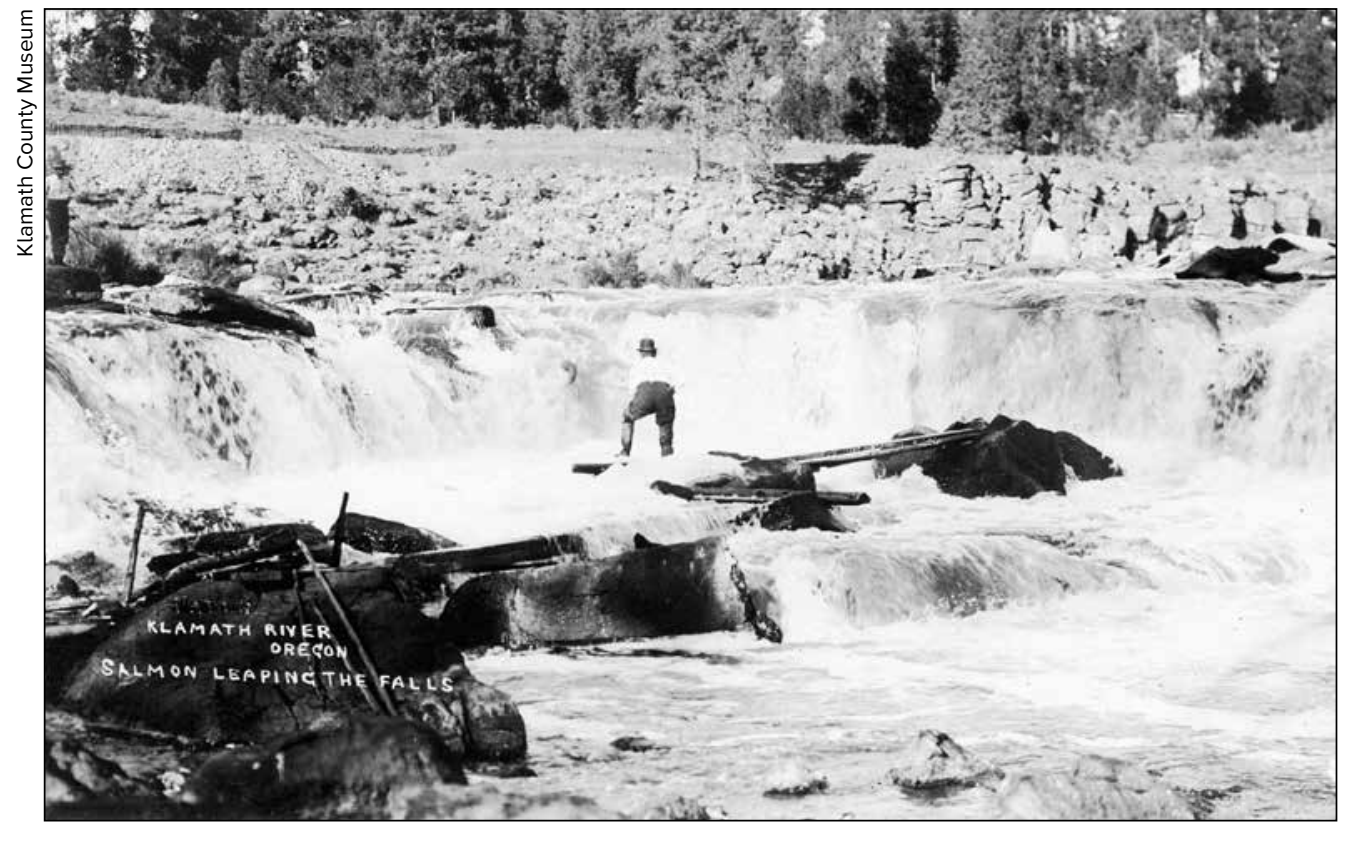

A FISHING PLATFORM is pictured on this 1910 postcard showing leaping salmon (to the left of the person on the platform) at Moonshine or Fishing Falls, downriver from the current location of J.C. Boyle Dam.

rail. ${ }^{66}$ During the early 1900 s, fishing here was reported to be world famous. ${ }^{67}$ Shovel Creek and the resort were regularly featured in trout-and salmon-fishing reports in San Francisco newspapers and magazine articles, including in a 1907 issue of Sunset Magazine. ${ }^{68} \mathrm{~A}$ photograph from Western Field magazine displays two Chinook salmon caught at the resort in 1902.69

The second general fishing area was a falls just downstream from the current location of J.C. Boyle Dam (RK 362). Referred to as Moonshine Falls or Fishing Falls, the falls, a leaping salmon, and a fishing platform are shown in a postcard from $1910 . .^{70}$ Merle Anderson, descendent of settlers Hiram and Mary Spencer for whom Spencer Creek was named, recalled salmon fishing here:

I can show you where my Dad used to go down there and spear them as they jumped over the falls. It was right below where John Boyle dam is now. I can show you exactly where he stood to take the salmon out. But I never knew anything about it because I was too young. They had a smoke house and they smoked them as long as the salmon came up, but then Copco put in that dam down below, above Hornbrook and that was the end of the salmon run. ${ }^{71}$
Fish from Moonshine Falls were also packed to Yreka and sold commercially. ${ }^{72}$ In 1910, an Oregon Fish and Game warden proposed a fish ladder around the falls. ${ }^{73}$ Moonshine Falls has since been physically altered, and flows today are greatly reduced due to water diversion to the J.C. Boyle powerhouse..$^{74} \mathrm{At}$ least until the $1960 \mathrm{~s}$, however, the remains of these falls could still be observed, and the remnants of the old fishing platform persisted. ${ }^{75}$

Upstream were fisheries for salmon at Link River (RK 410) in Klamath Falls. As the fish rested before attempting the city's namesake falls, they were vulnerable to capture. ${ }^{76}$ Link River was a center of harvest by Indians..$^{77}$ It also continued as a popular fishing location for early settlers of Klamath Falls. ${ }^{8}$ As at Negro Creek and Moonshine Falls, salmon harvested at Link River were packed to Yreka for commercial purposes. Baldwin took at least two photos of salmon fishing at Link River, one of which is reproduced below. ${ }^{79}$

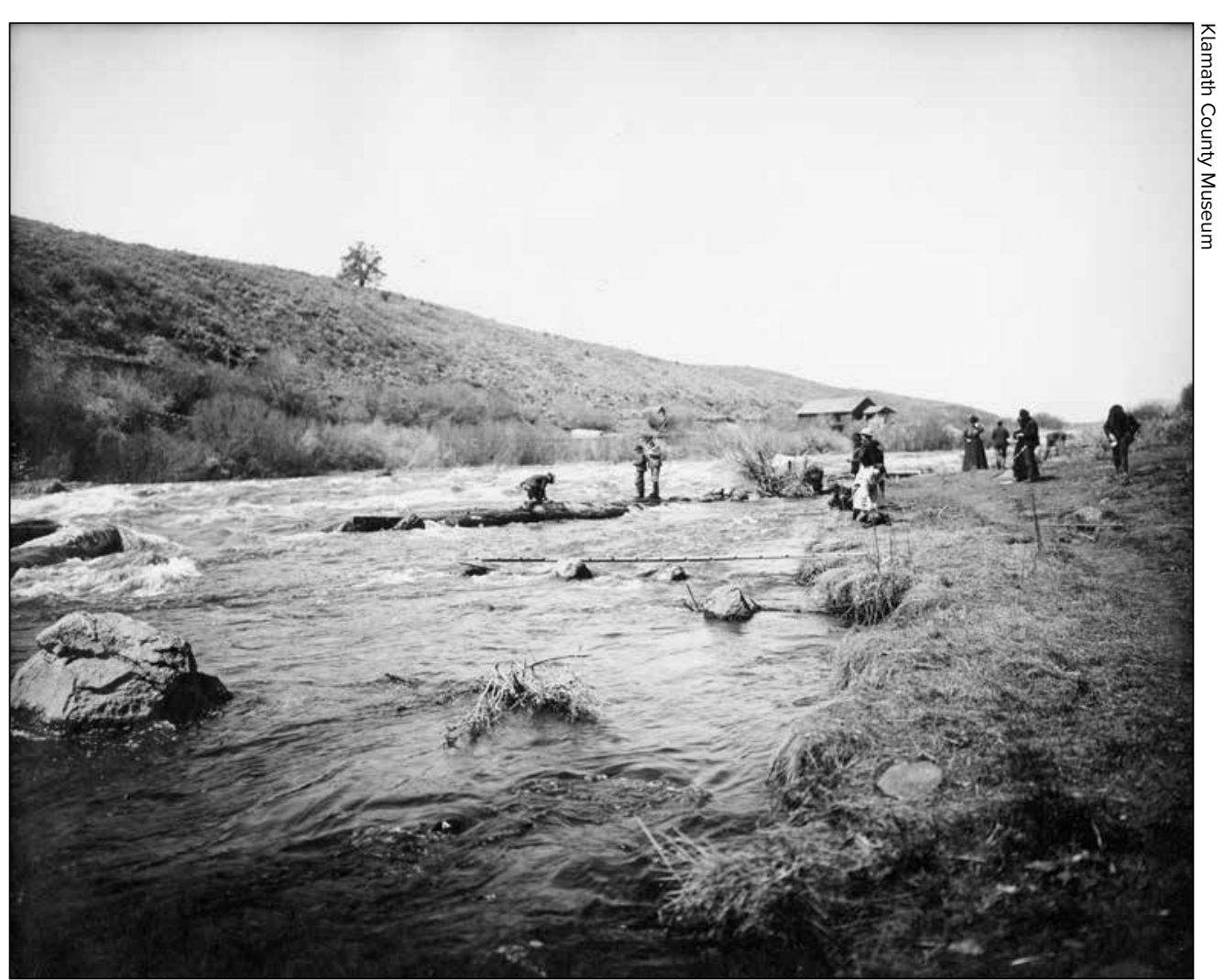

PHOTOGRAPHER MAUD BALDWIN took at least two photographs of salmon fishing on the Link River. This undated photograph shows fishing on the Link River below the Moore Mill. 


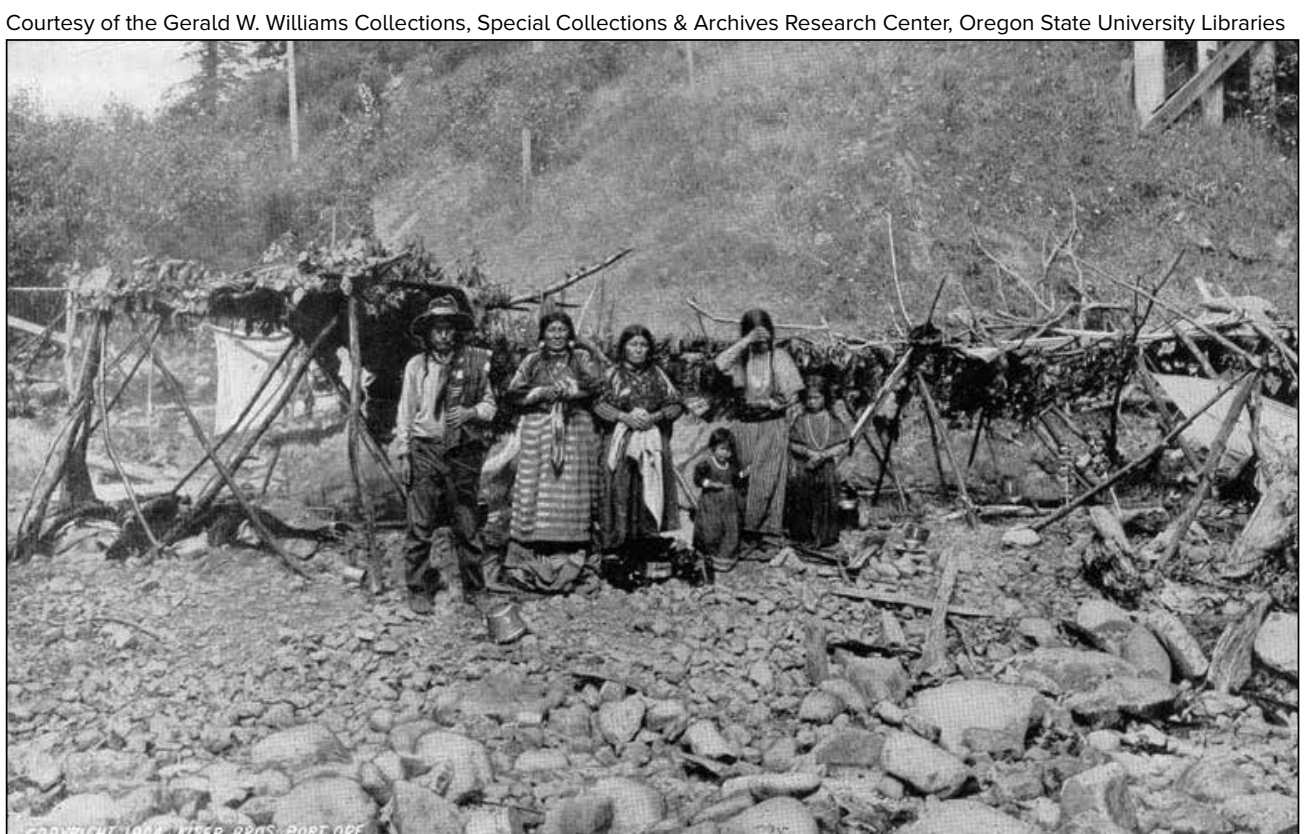

THIS 1904 PHOTOGRAPH of Indians on the former Klamath Reservation drying salmon for winter use is believed to have been taken in the vicinity of the lower Sprague River. The river's clear water and shallow riffles made it a preferred location for spearing salmon.

Last, we found many accounts of salmon fishing throughout the length of the Sprague River, a tributary (at about RK 450 to RK 585) upstream from Upper Klamath Lake. Indians did much of this fishing on the former Klamath Indian Reservation, until the federal government terminated the tribe and reservation in the 1950 (the Klamath Tribes won restoration in 1986). Waters of the Williamson River, located on the former reservation, and Upper Klamath Lake (outside Pelican Bay) were reportedly too dark in color and perhaps too deep to fish. The Sprague River, however, was an easy tributary in which to spear salmon. ${ }^{80}$ This may have been due to its clear water and shallow riffles. The Sprague River was used extensively for fishing salmon from late August through October (Table 3). Indians camped here near fishing holes, fished, and dried salmon for winter use..$^{81}$ Local historians believe that the above 1904 photo of Indians on the former reservation drying salmon was taken in the vicinity of the lower Sprague River (somewhere between the railroad bridge at the confluence with the Williamson River, to two kilometers or so upriver on the Spraque River)..$^{82}$ In 1941, based on affiant testimony, Superintendent B.G. Courtright of the Klamath Indian Agency provided to the Bureau of Indian Affairs District Counsel photos of several "Klamath Indian Salmon Fishing Holes" on the Spraque River. An index accompanied the photos. We were unable to find the images, but the index has survived. ${ }^{83}$ The map below shows most of these significant salmon-fishing locations. Although Courtright reported the stretch of fishable water to be from the Sprague River confluence with the Williamson River to Beatty, Oregon, five affiants (O.T. Anderson, Frank Obenchain, Carrie Schmitz, John Smith, and Eva Mose) reported salmon further upstream in the North Fork of the Sprague River, beyond the reservation boundary. ${ }^{84}$ One of the spearing techniques used in this vicinity for salmon, during the years 1902 to 1904, is detailed in an autobiography by Earl Moore:

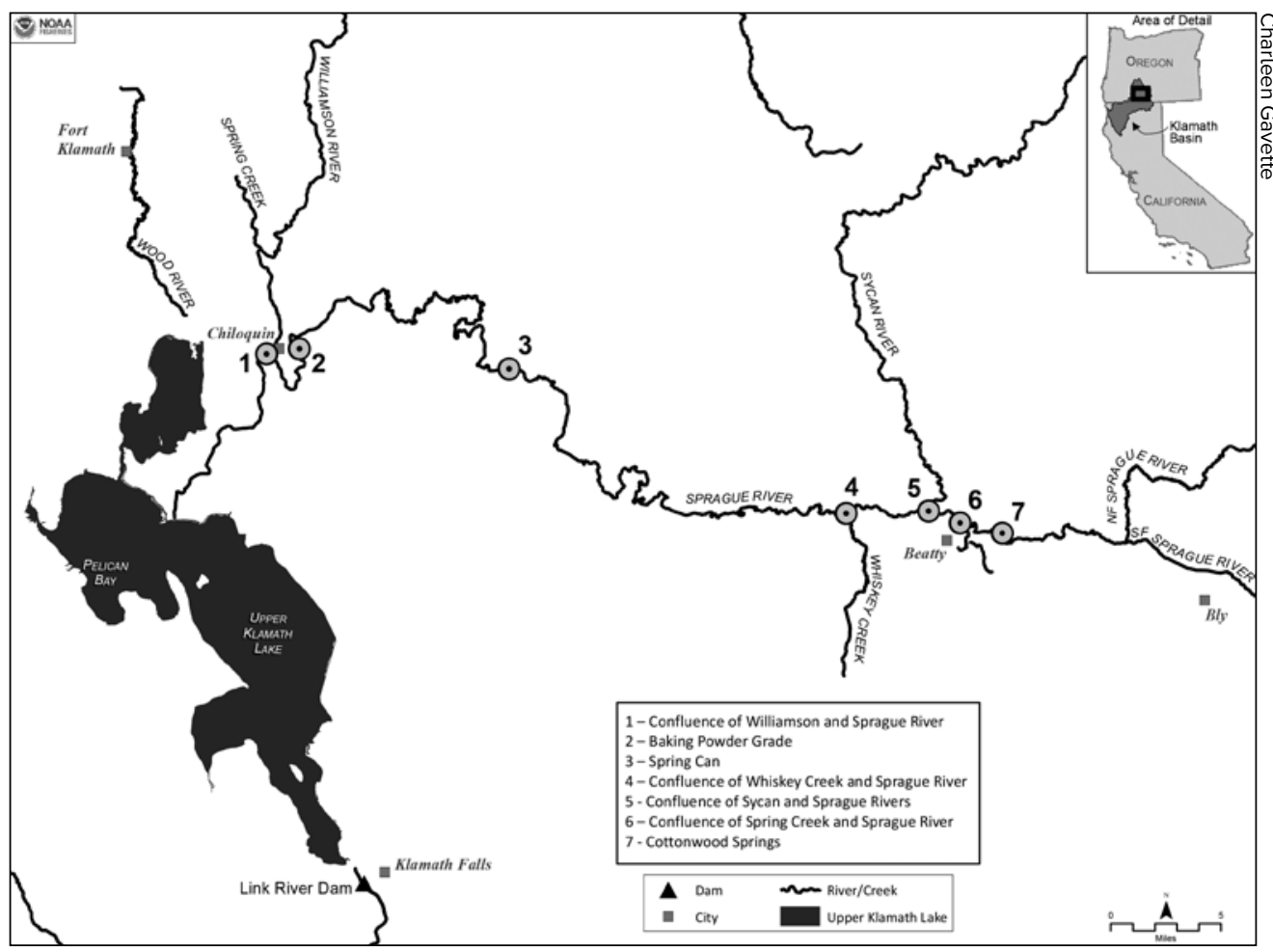

IN 1941 KLAMATH INDIAN AGENCY Superintendent B.G. Courtright provided the Bureau of Indian Affairs several photos and an index of Klamath Indian salmon-fishing holes on the Sprague River. This map shows most of the significant fishing locations. 
To be taken along on one of those night, salmon spearing trips with the ranch hands, well there was nothing dull about that night. Salmon runs were watched closely. A few of those red-meated beauties were a ranch table specialty; a rare treat from traditional beef. One fellow handled the fourtined spear while another slowly worked the long pole with pitch fire out over the salmon resting near the surface or grass bank dropoff. Then came the breathless, tense seconds as the spear poised for the strike under an uneasy, flickering light from the pitchfire basket. ${ }^{85}$

Salmon with flesh as Moore described would likely have been a spring migrating fish and highly marketable. Salmon harvested from the Sprague River benefited Indian trade, in particular for communities located at the eastern end of the former reservation. ${ }^{86}$ Newspaper articles and other records show that salmon harvested from the Sprague River were transported by Indians out of the Klamath Upper Basin to the towns of Lakeview and Pine Creek, Oregon, for sale and trade. ${ }^{87}$

\section{SEASONAL OCCURRENCE OF CHINOOK SALMON UPSTREAM} FROM IRON GATE DAM

Frémont's party traded for salmon in May 1846 at Link River. Those fish are what we now consider spring-run Chinook salmon. Albert S. Gatschet one of the first ethnographers and also a linguist - reported salmon up the Klamath River to the lake region much later in the year. Gatschet gathered information from Klamath Indian elders and published his work in 1890, providing the Klamath word (etchmû'na) for fall-migrating Chinook salmon and describing them as a purple salmon 0.9 to 1.2 meters long, arriving in the later part of November. ${ }^{88}$

Each migration of salmon generally has a different life history, or path, to adulthood, reproduction, and the persistence of the population. Springmigrating salmon, for example, have a life history that most commonly includes adults returning upstream from the ocean in the months of April through June, holding in protected freshwater pools and thermal refuges as their eggs mature, and then spawning in the late summer or early fall, with hatchlings having an extended period of growth in freshwater prior to their downstream migration to the ocean either in the late fall or spring. In contrast, fall-migrating salmon adults generally return upstream from the ocean in September through November, arrive with mature eggs, and do not hold in freshwater for extended periods. Fall-migrating salmon hatchlings generally move downstream to the ocean after a relatively brief period of growth in freshwater, usually beginning during February or March. Spring and fall migrations are the most distinct runs, but some rivers have summer and/or winter adult migrations as well. This appears to be the case for the Klamath Upper Basin. ${ }^{8}$

In considering restoration and reintroduction in the Klamath River upstream from IGD, it is important to understand the differences between seasonal migrations of salmon and their associated historical life histories. It is of interest to managers to know whether past threats, such as hydraulic mining or overfishing, diminished or extirpated any of these seasonal salmon life histories before dams blocked migration. In our summary of seasonal observations, we regarded salmon observed between December 1 and March 31 to have been winter migration; between April 1 and June 30 to have been spring migration; between July 1 and August 31 to have been summer migration; and between September 1 and November 30 to have been fall migration. The following affidavit from 1946 is one example of information about seasonal migration and fish size we found:

I am 70 years old and was born at Whiskey Creek on the Klamath Indian Reservation. . . . I used to fish for salmon every year in September and October and did spear fishing at Cottonwood Springs. Some salmon weighed as much as 40 pounds [18.1 kilograms $(\mathrm{kg})]$... Some of the Indians sold salmon at Lakeview and Klamath Falls for \$1.50, \$2.00 and \$2.50 a fish. They would haul 30 to 40 fish to Lakeview from Cottonwood Springs. These Indians are all dead now. ${ }^{90}$

Clearly, salmon harvested at this time of year were an important part of commerce at this location. Spring-migrating salmon in the Klamath River Basin were also important historically and, according to one source, outnumbered fall-migrating Chinook salmon in the Klamath Upper Basin. This same source also noted: "There were two fairly distinct runs, noted even to the headwaters. The first was the spring or summer run, which was followed by the fall run." 91

We found fourteen records documenting spring migration and one document that concluded there was no spring run to the Klamath Upper Basin. ${ }^{92}$ Nearly all of the records of spring migration of salmon we found upstream from IGD were in the Klamath Upper Basin. We found four accounts of winter migration and seven accounts of summer migration. By far, we found the greatest number of historical salmon observations (fifty) during the fall months, with many during the month of October. Fall observations were at various locations upstream from IGD (Table 3). 
As we explain below, however, these fall observations should be viewed with caution in interpreting the historical salmon life histories. A report by the Commissioner of the U.S. Bureau of Fisheries provides some notable clues about spring or summer migrations upstream from IGD and, thus, about historical Klamath Upper Basin Chinook salmon life histories. Anticipating that salmon would be blocked by Copco 1 Dam, and intending to compensate for the loss of upstream habitat, the Bureau of Fisheries in 1910 established a weir at Klamathon, California, about sixteen kilometers downstream from the construction of the dam, and harvested salmon eggs there for hatchery propagation..$^{93} \mathrm{It}$ has been conventional wisdom that, after 1910, the Klamathon weir blocked all salmon and anadromous fish, year round, from upstream migration. ${ }^{94}$

But the Bureau of Fisheries report shows that this conventional wisdom was flawed. The annual operation of the Klamathon weir, first erected in 1910, took place only from September through December and therefore only blocked salmon runs during those months. Before these seasonal operations began, the report identifies salmon migrating past the Klamathon vicinity as spring-run or summer-run. 95 Thus, the salmon that were observed upstream in the Klamath Upper Basin after 1910 in the fall, including the salmon captured on the Klamath Indian Reservation in October 1911 and sold in Lakeview, Oregon (Table 2), could only have been spring migrating or summer migrating. ${ }^{96}$ With this life history, they would have returned to the Klamath Upper Basin before September, and then held upstream in deep, groundwater-influenced habitats until their eggs matured. Some of these holding areas may have been in the deep, cool water of the lower Williamson River, just above Upper Klamath Lake. ${ }^{97}$ If so, those fish likely contributed to the observed spawning and harvest beginning in late August in the Sprague River (see Table 3). Additional data and our analysis support this conclusion. Where salmon entered the Klamath Upper Basin at Link River, the distribution of observations was about equal for winter, spring, and summer/fall periods. The seasonal distribution of observations specific to the tributary rivers of the Upper Klamath Lake, however, did not match those from Link River, with zero accounts from the tributaries during winter, seven during spring, and twenty-eight during summer and fall (see Table 3). Many of these summer and fall observations were in the Sprague River. While the seasonal observation of salmon in the remote tributaries of Upper Klamath Lake may have been less likely than at Link River, the available information suggests that returns to the tributary rivers of Upper Klamath Lake were probably made up of salmon with various migration times and associated life histories. The multiple life histories of a similar species in the Klamath Upper Basin, redband trout, support this conclusion. ${ }^{98}$

\section{THE PERSISTENCE AND EXTIRPATION OF CHINOOK SALMON}

\section{MIGRATION UPSTREAM FROM IRON GATE DAM}

Historians have been uncertain about when salmon migrations were blocked from the Klamath Upper Basin and the former Klamath Indian reservation. ${ }^{9}$ One author concluded that migrations to the Sprague and Williamson rivers were probably extirpated before $1900 .{ }^{100} \mathrm{~A}$ review of Chinook population stated that migration was blocked at Klamath Falls by the Link River hydroelectric dam in $1895 .{ }^{101}$ Others have concluded that migrations persisted upstream from the first hydroelectric dam until 1917, or its completion in 1918. ${ }^{102}$ Lane and Lane Associates' summary of available information put the year between 1908 and $1918 .{ }^{103}$ Courtright was specific in setting 1911 as the year migrations ceased. Another account stated that the migrations stopped in $1912 .{ }^{104}$ Accordingly, Lane and Lane Associates proposed that, to resolve the issue of when migrations ceased, "the skills needed to unravel the mystery are those of fishway experts." ${ }^{105}$ To pinpoint the date, we examined the question from three perspectives: the historical record, the role of the Bureau of Fisheries weir, and fish-passage hydraulics.

The failure of migrations to the Klamath Upper Basin in 1913 was frontpage news for the Klamath Falls Evening Herald. It was a grave matter. Mos members of the Klamath Tribes participated in subsistence fishing for salmon in Upper Klamath Lake and the Williamson and Sprague rivers. ${ }^{106}$ Reliant on those salmon, Indians, along with local sportsmen, demanded an investigation. ${ }^{107}$ The Evening Herald reported that the Indians believed the cause to be the Bureau of Fisheries weir at Klamathon. ${ }^{108}$ Representatives from Oregon and COPCO concurred. ${ }^{109}$

More recent reports state that the Klamathon weir blocked all salmon and anadromous fish from upstream migration. ${ }^{10}$ If this were the case, however, there would be no records of anadromous fish upstream from Klamathon after 1910. To the contrary, newspaper articles corroborate the Klamathon weir report that migration continued after 1910 (Table 2). In 1911, salmon were still being harvested from the Klamath Upper Basin and sold commercially in Lakeview, Oregon."' According to the Evening Herald, a steelhead trout (an ocean-going fish) was caught at Klamath Falls in February $1912 .{ }^{12}$ According to the San Francisco Call in August 1912, salmon were observed upstream from the ongoing construction on the Copco 1 Dam, and in September 1912, the 


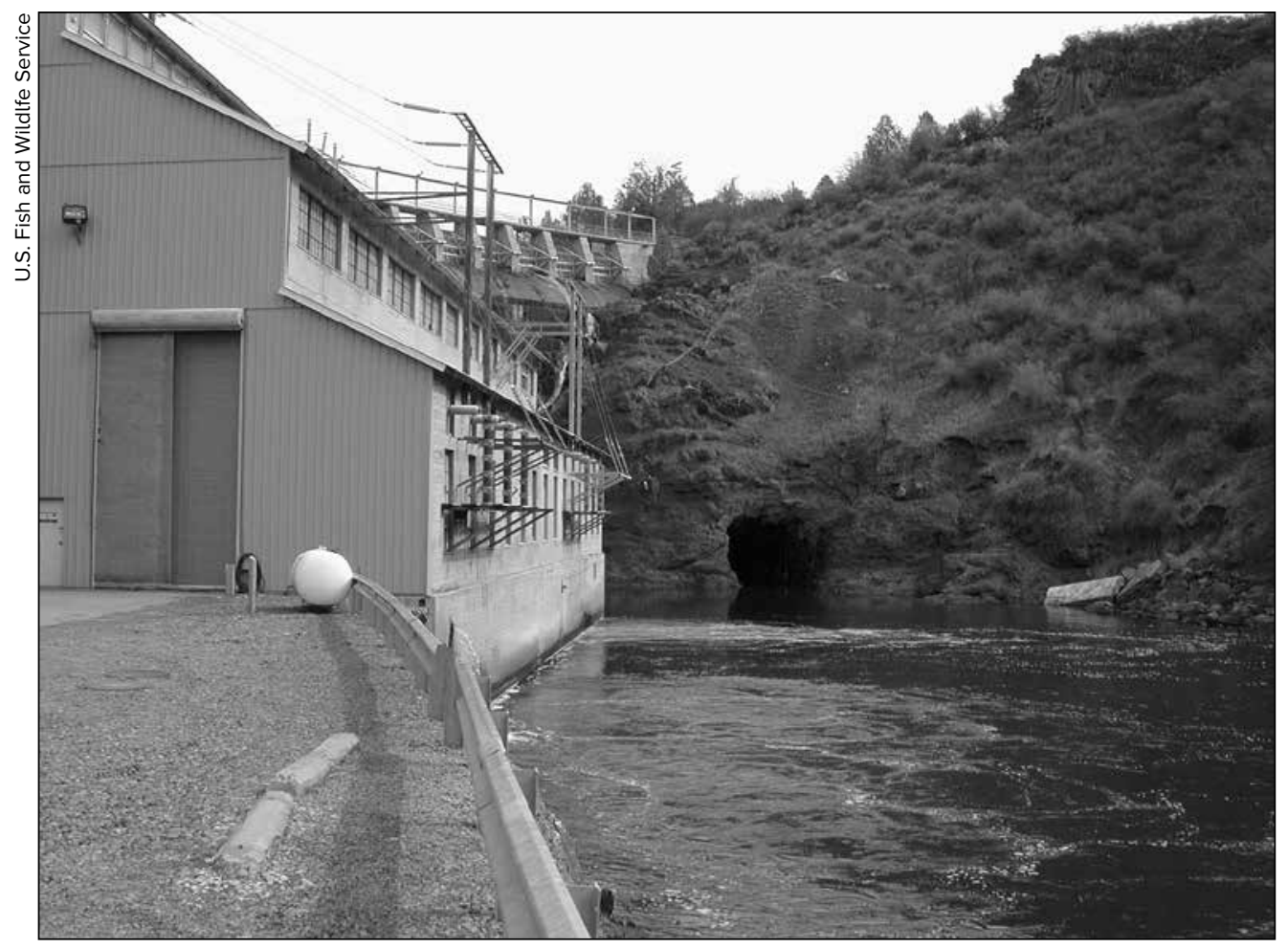

THE TUNNEL used to divert the Klamath River during the construction of Copco 1 Dam is stil apparent. This photo was taken in 2003.

Portland Morning Oregonian reported that salmon were running strong in Link River and vicinity. ${ }^{113}$ Thus, salmon migrations did not, as alleged, cease in 1910.

As recommended by Lane and Lane Associates, the question regarding whether migration was first blocked by the construction of Copco 1 Dam and when, can be addressed by examining fish-passage hydraulics - that is, the relationship between the velocity of water going through the dam's diversion tunnel, through which the fish would have had to pass to continue upstream, and the swimming capability of the salmon. ${ }^{14}$ To assess the likelihood of fish passage we reviewed construction and engineering details, historical flows, and information on hydraulics at the time of construction. We focused on the Copco 1 diversion tunnel pictured above.

We estimate the likelihood of fish passage based on flow conditions at the site during dam construction. As of October 12, 1912, when water was first diverted through the headgates and into the diversion tunnel at the Copco 1 site, and assuming optimal conditions for fish passage, the lowest estimated velocity in the tunnel was approximately 3.3 meters per second (mps). ${ }^{115}$ While Chinook salmon are able to swim at burst speeds up to 6.8 $\mathrm{mps}$, they can only maintain such activity for 5 to 10 seconds. ${ }^{116}$ The maximum swimming distance of Chinook salmon under ideal conditions at a wate velocity of $3.3 \mathrm{mps}$ is estimated to be 35 meters, well short of the 108.5 meters required to get through the tunnel, let alone the headgate entrance. Even if the velocity at the walls or corners of the tunnel was 50 percent lower (o $1.7 \mathrm{mps}$ ), the maximum swimming distance of Chinook salmon under ideal conditions would be about 51 meters, or less than half the distance through the tunnel. ${ }^{17}$ Thus, based on this analysis, migration upstream from Copco 1 Dam was effectively blocked on October 12, 1912.

Somewhat confusing, in identifying October 1912 as the date when migrations were blocked, were the reports of salmon in the Klamath Upper Basin in the fall of 1912 (Table 2). Spring and summer migrating salmon that had passed the Klamathon weir before September 1912, and the Copco 1 Dam construction site prior to October 12,1912, were observed in the Klamath Upper Basin that same year, misleading observers to conclude that the runs did not cease in 1912. Assertions that the blockage of the salmon migration was due to the construction of the Bureau of Fisheries weir in 1910 disregarded the absence of annual weir operation prior to September and may even have been specious arguments.

By late 1914, the Medford Tribune reported that salmon migration had been blocked to all bodies of water upstream from Copco 1 Dam.118 While John Smith recalled in the 1940 s that migrations continued until about 1914 or 1915, we found no additional documentation or records indicating the occurrence of ocean-going salmon upstream from Copco 1 Dam after $1912^{11}$ The downstream completion of Copco 2 Dam in 1925 and IGD in 1962 further restricted runs of Chinook salmon.

Using the accounts of early explorers Peter Skene Ogden and John C. Frémont, documentation from pioneer ethnographer Albert Gatschet, images from turn-of-the-century photographer Maud Baldwin, and information from archaeologists, anthropologists, magazines, newspapers, and government reports, we have updated the historical record of salmon upstream from the location of IGD. While the expanded record now contains several references suggesting that salmon did not migrate upstream of Link River, the information as a whole is conclusive that salmon historically migrated to the Klamath Upper Basin. Reports to the contrary may have been during periods of intermittent interruption. Examined in total, the updated record 
now provides a glimpse of the characteristics of historical migrations. Most of the observations of returning adult salmon occurred in the fall, but they were recorded during all seasons of the year, suggesting that migrations were seasonally diverse and consisted of various salmon life histories. The majority of accounts indicate that salmon were abundant and provided robust in-river Tribal and recreational fisheries upstream from IGD. In addition, migrations were prolific enough to support four general fishing areas that included small-scale commercial harvest at least through 1911. The greatest focus on adult Chinook salmon was in the Sprague River in the fall and was associated with significant harvest.

This analysis resolves the question of when historical migrations of Chinook salmon to the Klamath Upper Basin ceased. It also makes it clear that the Bureau of Commercial Fisheries efforts did not destroy salmon migrations as alleged. While salmon runs were impacted by an 1889 dam at Klamathon, California, by exploitation by in-river fisheries supporting canneries, by abusive mining practices, and by other destruction of their habitat, we found that migrations persisted in the Klamath Upper Basin through the fall of 1912, when they were completely excluded by an early phase of the construction of Copco 1 Dam.

Blocked salmon migrations are now slated to be reversed either through fishways or dam removal, enabling adult salmon to migrate to historical habitats. The diverse seasonal migrations of salmon historically and the life histories likely associated with those migrations would have provided various strategies for surviving to reproduce, an important element for viable populations. ${ }^{120}$ Diversity in salmon populations can provide a similar benefit to diversity in financial portfolios (for salmon populations, this is referred to as the portfolio effect), spreading risk and buffering fluctuations in the environment. ${ }^{12}$ The benefits of the portfolio effect have been demonstrated in the robust salmon population of Bristol Bay, Alaska, and threatened populations of the Snake River, Idaho, and the Sacramento and San Joaquin rivers of California. ${ }^{122}$ The portfolio effect in salmon populations contributes to their resilience and ability to survive local ecological disturbance (such as floods and droughts) and unnatural changes ranging from land use to climate change or perhaps years where water quality is poor in portions of the river. ${ }^{123}$

As managers consider habitat restoration, reintroduction, and associated monitoring plans for Chinook salmon upstream from the current location of IGD and in the Klamath Upper Basin, they will likely look to the historical record for guidance. Our review substantiates the historical persistence of salmon, their migration characteristics, and the broad population baseline that will be key to future commercial, recreational, and Tribal fisheries in the Klamath River and beyond.
TABLE 1A: DOCUMENTATION OF THE PRESENCE AND EXTENT OF CHINOOK SALMON DISTRIBUTION IN THE KLAMATH RIVER SYSTEM UPSTREAM FROM IRON GATE DAM AS PUBLISHED IN HAMILTON ET AL. (2005)

\begin{tabular}{|c|c|c|}
\hline \multicolumn{2}{|r|}{ DOCUMENTATION } & $\begin{array}{l}\text { Chinook } \\
\text { Salmon } \\
\text { Runs in } \\
\text { Klamath }\end{array}$ \\
\hline \multirow{2}{*}{$\begin{array}{l}\mathscr{U} \\
\stackrel{\Xi}{\sigma} \\
\underline{\Xi}\end{array}$} & $\begin{array}{l}\text { Photo 2: Link River salmon "fishing" around } 1860 \text {. Site of present Klamath Falls., } \\
\text { Klamath County Historical Society, } 1860 \text {. }\end{array}$ & $\checkmark$ \\
\hline & $\begin{array}{l}\text { Photo 3: Gentlemen display their catch while salmon fishing on the rapids of Link } \\
\text { River, 1891. Klamath County Historical Society, } 1891 \text {. }\end{array}$ & $\checkmark$ \\
\hline \multirow{11}{*}{ 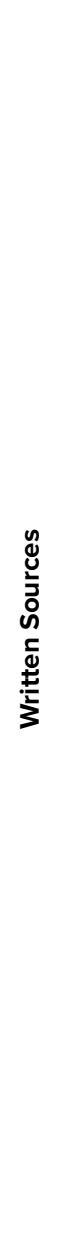 } & $\begin{array}{l}\text { A. Gatschet, The Klamath Indians of Southwestern Oregon (Washington, D.C.: USDI } \\
\text { U.S. Geographical and Geological Survey of the Rocky Mountain Region, 1890), 711. }\end{array}$ & $\checkmark$ \\
\hline & L. Spier, Klamath Ethnography (Berkeley: University of California Press, 1930). & $\checkmark$ \\
\hline & $\begin{array}{l}\text { J. Wales and M. Coots, “Efficiency of Chinook Salmon Spawning in Fall Creek, } \\
\text { California," Transactions of the American Fisheries Society } 84 \text { (1954): 134-49. }\end{array}$ & \\
\hline & $\begin{array}{l}\text { L. Cressman, W. Haag, W. Laughlin, "Klamath Prehistory: The Prehistory of the Culture } \\
\text { of the Klamath Lake Area, Oregon." Transactions of the American Philosophical } \\
\text { Society 46:4 (1956): 375-513. }\end{array}$ & $\checkmark$ \\
\hline & $\begin{array}{l}\text { M. Coots, The Spawning Efficiency of King Salmon (Oncorhynchus tshawytscha) in } \\
\text { Fall Creek, Siskiyou County: 1954-55 Investigations, Report 57-1, Redding, California } \\
\text { Department of Fish and Game, Inland Fisheries, } 1967\end{array}$ & \\
\hline & $\begin{array}{l}\text { A. Kroeber and S. Barrett, "Fishing Among the Indians of Northwestern California," } \\
\text { Anthropological Records 21:1 (1960): } 5 .\end{array}$ & $\checkmark$ \\
\hline & $\begin{array}{l}\text { M. Coots, Klamath River } 1957 \text { and } 1958 \text { King Salmon Counts, Klamathon Racks } \\
\text { Siskiyou County, Report No. 62, Redding, California Department of Fish and Game, } \\
\text { Inland Fisheries, } 1962 .\end{array}$ & $\checkmark$ \\
\hline & $\begin{array}{l}\text { M. Coots, California Department of Fish and Game, to Jack Hanel, Pacific Power and } \\
\text { Light Company, July 1, 1965, in J. Hanel, ed., Redding, Calif. } 1965 .\end{array}$ & \\
\hline & $\begin{array}{l}\text { J. Fortune, A. Gerlach, and J. Hanel, A Study to Determine the Feasibility of } \\
\text { Establishing Salmon and Steelhead in the Upper Klamath Basin, Oregon State Game } \\
\text { Commission and Pacific Power and Light Company, Portland, Oregon, } 1966 .\end{array}$ & $\checkmark$ \\
\hline & $\begin{array}{l}\text { Lane and Lane Associates, The Copco Dams and the Fisheries of the Klamath Tribe: } \\
\text { Report of Lane and Lane Associates to the USDI Bureau of Indian Affairs, Portland, } \\
\text { Oregon, } 1981 .\end{array}$ & $\checkmark$ \\
\hline & $\begin{array}{l}\text { W. Nehlsen, J. Williams, and J. Lichatowich, “Pacific salmon at the crossroads: Stocks } \\
\text { at risk from California, Oregon, Idaho, and Washington," Fisheries 16:2 (1991):4-21. }\end{array}$ & \\
\hline
\end{tabular}




\begin{tabular}{|c|c|c|}
\hline \multicolumn{2}{|r|}{ DOCUMENTATION } & \multirow{2}{*}{$\begin{array}{c}\text { Chinook } \\
\text { Salmon } \\
\text { Runs in } \\
\text { Klamath } \\
\text { Upper Basin }\end{array}$} \\
\hline \multirow{3}{*}{ 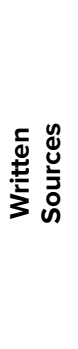 } & $\begin{array}{l}\text { USDI Bureau of Land Management, USDA Forest Service, Environmental Protection } \\
\text { Agency, USDI Fish and Wildlife Service, Spencer Creek Pilot Watershed Analysis, } \\
\text { Klamath Falls, Ore., USDI Bureau of Land Management, Klamath Falls Field Office, } \\
1995 .\end{array}$ & \\
\hline & $\begin{array}{l}\text { R. Thurow, D. Lee, and B. Rieman, "Distribution and Status of Seven Native Salmonids } \\
\text { in the Interior Columbia River Basin and Portions of the Klamath River and Great } \\
\text { Basins," North American Journal of Fisheries Management } 17 \text { (1997): 1094-1110. }\end{array}$ & $\checkmark$ \\
\hline & $\begin{array}{l}\text { P. Moyle, Inland Fishes of California, 2nd ed. (Berkeley: University of California Press, } \\
\text { 2002). }\end{array}$ & $\checkmark$ \\
\hline$\underset{\underline{\underline{m}}}{\sum_{\underline{0}}^{3}}$ & Robert Scarber, interview by author, 2004. & $\checkmark$ \\
\hline
\end{tabular}

TABLE 1B: ADDITIONAL DOCUMENTATION OF THE PRESENCE AND EXTENT OF CHINOOK SALMON DISTRIBUTION IN THE KLAMATH RIVER SYSTEM UPSTREAM FROM IRON GATE DAM SINCE HAMILTON ET AL. (2005) PUBLICATION

\begin{tabular}{|c|c|c|}
\hline \multicolumn{2}{|r|}{ DOCUMENTATION } & \multirow{2}{*}{$\begin{array}{c}\text { Chinook } \\
\text { Salmon } \\
\text { Runs in } \\
\text { Klamath } \\
\text { Upper Basin }\end{array}$} \\
\hline \multirow{7}{*}{ 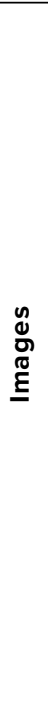 } & $\begin{array}{l}\text { "My Best Day's Catch" at Shovel Creek, in F.A. Judah, “A Siskiyou Vacation," Western } \\
\text { Field 1:5 (1902): } 266 .\end{array}$ & \\
\hline & $\begin{array}{l}\text { "Drying salmon, Klamath Indian Reservation" (1904), Gerald W. Williams Collections } \\
\text { (MSS Williams G) [hereafter Gerald W. Williams Collections], Oregon State University } \\
\text { Special Collections and Archives Research Center, Corvallis, Oregon [hereafter OSU } \\
\text { Special Collections]. }\end{array}$ & $\checkmark$ \\
\hline & Postcard of Salmon Leaping Falls (dated 1910), Klamath County Museum. & \\
\hline & $\begin{array}{l}\text { "Fishing for salmon in Link River below the Moore Mill and Link River Falls" (undated) } \\
\text { in Floyd Wynne, "Link River," Klamath Echoes 1:4 (1967) Centennial Issue, Part 1. }\end{array}$ & $\checkmark$ \\
\hline & $\begin{array}{l}\text { "25\# salmon caught by an Indian who lived upstream from Link River bridge" } \\
\text { (undated), SHLO14, series 1, Alfred D. Collier Collection (1880-1982), Shaw Historical } \\
\text { Library, Oregon Institute of Technology, Klamath Falls, Oregon. }\end{array}$ & $\checkmark$ \\
\hline & $\begin{array}{l}\text { Salmon fishing at Fall Creek (1950) in J. Wales, Management of King Salmon Spawning } \\
\text { in the Klamath River, Siskiyou County, Bureau of Fish Conservation, California Division } \\
\text { of Fish and Game, } 1950 \text {. }\end{array}$ & \\
\hline & $\begin{array}{l}\text { Williamson River salmon featured in C.F. Holder, Game Fishes of the World (London: } \\
\text { Hodder and Stoughton, 1913). }\end{array}$ & $\checkmark$ \\
\hline
\end{tabular}

\begin{tabular}{|c|c|c|}
\hline & DOCUMENTATION & $\begin{array}{l}\text { Chinook } \\
\text { Salmon } \\
\text { Runs in } \\
\text { Klamath }\end{array}$ \\
\hline \multirow{20}{*}{ 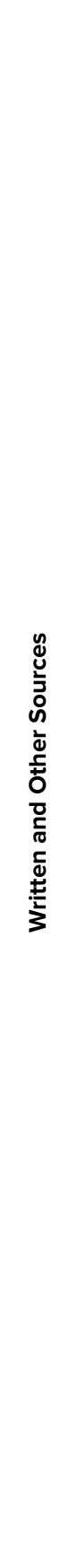 } & $\begin{array}{l}\text { Jeffrey LaLande, First Over the Siskiyous: Peter Skene Ogden's 1826-1827 Journey } \\
\text { through the Oregon-California Borderlands (Portland: OHS Press, 1987). }\end{array}$ & \\
\hline & $\begin{array}{l}\text { Frémont (1846) in D. Walker, Bear Flag Rising: The Conquest of Califlornia, } 1846 \text { (New } \\
\text { York: Tom Doherty Associates, 1999). }\end{array}$ & $\checkmark$ \\
\hline & Frémont (1846) in D. Helfrich, "The First Boats," Klamath Echoes 1:2 (1965). & $\checkmark$ \\
\hline & Stephen Powers, Tribes of California (Berkeley: University of California Press, 1877). & \\
\hline & Linkville Star, May 10, 1884. & $\checkmark$ \\
\hline & $\begin{array}{l}\text { Correspondence (1886) between J. Merrill and G. Brown Goode and S.F. Baird from Ft. } \\
\text { Klamath, Oregon, Record Unit 305, Accession no. 19748, Smithsonian Institution Archives, } \\
\text { Washington, D.C. }\end{array}$ & $\checkmark$ \\
\hline & The Great Klamath Basin and Klamath County (Linkville: Klamath County Museum, 1888), 2. & $\checkmark$ \\
\hline & $\begin{array}{l}\text { "The Pacific Coast: Seven Men Have Been Arrested for Violating the Salmon Law on the } \\
\text { Klamath River Near the State Line, and the Dam Complained of by Governor Pennoyer } \\
\text { has been Removed," Oregon Scout, October 17, 1889. }\end{array}$ & \\
\hline & "Salmon Have Free Run up the River," Yreka Journal, September 10, 1890. & $\checkmark$ \\
\hline & "Rod and Reel," San Francisco Call, October 5, 1890. & $\checkmark$ \\
\hline & $\begin{array}{l}\text { "Pacific Coast News: Incidents of the Week in Condensed Form-Salmon Are Now } \\
\text { Running up the Klamath River Clear to Lakes at Its Head. The Dam at Klamath City Was } \\
\text { Washed Away Last Winter," Sausalito News, October 10, } 1890 \text {. }\end{array}$ & $\checkmark$ \\
\hline & "The Fish Ladder at Pokegama," Yreka Journal, October 4, 1893. & $\checkmark$ \\
\hline & $\begin{array}{l}\text { "The Twentieth Century-First Salmon of the Season Was on Sale at Fitzgerald's Market } \\
\text { Last Week. The Fish Came from Sprague River," Lake County Examiner, October 10, } 1901 .\end{array}$ & $\checkmark$ \\
\hline & Judah, “A Siskiyou Vacation,” 262-67. & \\
\hline & $\begin{array}{l}\text { "Local News: Roy Wright Has Caught Four Large Salmon from the River at This Place } \\
\text { the Past Week," Klamath Republican, September 18, } 1902 .\end{array}$ & $\checkmark$ \\
\hline & $\begin{array}{l}\text { "Local News: It Is Reported That the Fish Ladder at Klamathon Is a Poor Arrangement," } \\
\text { Klamath Republican, October } 16,1902 .\end{array}$ & $\checkmark$ \\
\hline & $\begin{array}{l}\text { "Trout Streams Are Beckoning Angling Hosts: Stories of the Sport on the Klamath } \\
\text { River Stir the Blood of Many Sportsmen," San Francisco Call, June 4, } 1904 .\end{array}$ & \\
\hline & $\begin{array}{l}\text { Oregon Department of Fisheries, Annual Report of the Master Fish Warden } 1904 \\
\text { (Salem: Oregon Department of Fisheries, 1905). }\end{array}$ & \\
\hline & $\begin{array}{l}\text { F.A. Shaver, with Arthur P. Rose, R.F. Steele, and A.E. Adams, comps., Illustrated } \\
\text { History of Central Oregon Embracing Wasco, Sherman, Gilliam, Wheeler, Crook, } \\
\text { Lake, and Klamath Counties - State of Oregon (Spokane, Wash.: Western Historical } \\
\text { Publishing Company, 1905). }\end{array}$ & $\checkmark$ \\
\hline & $\begin{array}{l}\text { Klamath Falls Chamber of Commerce, Klamath Falls Oregon: The New Eldorado of } \\
\text { the West - Always Health, Wealth, and Happiness (1906), Digital Collection, Western } \\
\text { Waters Digital Library, Courtesy of University of Oregon Libraries. }\end{array}$ & $\checkmark$ \\
\hline
\end{tabular}

Hamilton et al., Persistence and Characteristics of Chinook Salmon Migrations 


\begin{tabular}{|c|c|c|}
\hline & DOCUMENTATION & $\begin{array}{l}\text { Chinook } \\
\text { Salmon } \\
\text { Runs in } \\
\text { Klamath }\end{array}$ \\
\hline & A. Cumming, "Angling on the Klamath," Sunset (April 1907), 573-83. & \\
\hline & $\begin{array}{l}\text { "Keno Items: Arrested Several Parties for Fishing for Salmon Otherwise Than with a } \\
\text { Hook and Line," Klamath Republican, September 16, 1909, p. } 1 .\end{array}$ & \\
\hline & $\begin{array}{l}\text { "Where Shovel Creek Reaches the Klamath: The Famous Fishing and Hunting Ground } \\
\text { of Northen California," San Francisco Call, June 27, } 1909 .\end{array}$ & \\
\hline & "Crater Lake: Where a Mountain Fell Inward," San Francisco Call, August 15, 1907. & $\checkmark$ \\
\hline & R. Steele, “The Big One up Shovel Creek," Western Field (October 1909): 49-56. & \\
\hline & H. Whyte, "Fall Outings for Everyone," The Outings Magazine LV (1909), 254-55. & \\
\hline & "Build the Fish Ladder," Klamath Falls Express, April 14, 1910. & \\
\hline & $\begin{array}{l}\text { S. Barrett, "The Material Culture of the Klamath Lake and Modoc Indians of } \\
\text { Northeastern California and Southern Oregon," University of California Publications in } \\
\text { American Archaelogy and Ethnology 5:4 (June 27, 1910): 239-52. }\end{array}$ & $\checkmark$ \\
\hline & “Fish Ladder Needed,” Oregonian, April 10, 1910. & \\
\hline & "Klamath Has Gun Club," Oregonian, October 30, 1910, p. 2. & \\
\hline 兽 & "State News," Salem Daily Capitol Journal, April 12, 1910, p. 7. & \\
\hline$\stackrel{\square}{\Phi}$ & "Fish Laws Demanded," Morning Oregonian, December 10, 1910, p. 3. & $\checkmark$ \\
\hline$\frac{0}{c}$ & "Bills Passed Legislature: New Senate Bills," Coos Bay Times, February 9, 1911, p. 4. & \\
\hline$\frac{0}{5}$ & "Rogue River Bill Vetoed," Coos Bay Times, February 27, 1911, p. 2. & \\
\hline 蒙 & "Indian Fishers Sell Fine Wares," Evening Herald, October 15, 1911. & $\checkmark$ \\
\hline & $\begin{array}{l}\text { "Some Salmon Were Brought into Town the Forepart of the Week by the Indians } \\
\text { from the Klamath Reservation. The Fish Were Caught in Sprague River," Lake County } \\
\text { Examiner, October 12, 1911. }\end{array}$ & $\checkmark$ \\
\hline & Lake County Examiner, October 19, 1911. & $\checkmark$ \\
\hline & $\begin{array}{l}\text { Oregon Department of Fisheries, Report of the Master Fish Warden: Biennial Report of } \\
\text { the Department of Fisheries of the State of Oregon: Natural Obstructions-Keno Falls, } \\
\text { (Salem, Ore., 1911), } 40 \text {. }\end{array}$ & \\
\hline & "Crippled Fisherman Handy with the Rod," San Francisco Call, September 24, 1911. & \\
\hline & "Salmon Running in Rivers," Morning Oregonian, September 9, 1912, p. 3. & $\checkmark$ \\
\hline & $\begin{array}{l}\text { Photo caption “J. Bernard Frisbee of Berkeley with a Limit of Rainbow trout at Klamath } \\
\text { Hot Springs. The Fall Run of Salmon and Trout is Now On," San Francisco Call, August } \\
\text { 29, 1912. }\end{array}$ & \\
\hline & $\begin{array}{l}\text { "Inspect the Klamath Dam - Officials Will Investigate Salmon Shortage," Evening } \\
\text { Herald (Klamath Falls), October 28, 1913. }\end{array}$ & $\checkmark$ \\
\hline & $\begin{array}{l}\text { "Indians Oppose Salmon Racks at Hatcheries - Future Supply in Serious Danger," } \\
\text { Klamath Evening Herald, November 3, 1913, p. } 1 \text {. }\end{array}$ & $\checkmark$ \\
\hline
\end{tabular}

\begin{tabular}{|c|c|c|}
\hline \multicolumn{2}{|c|}{ DOCUMENTATION } & \multirow{2}{*}{\begin{tabular}{|c}
$\begin{array}{c}\text { Chinook } \\
\text { Salmon } \\
\text { Runs in } \\
\text { Klamath } \\
\text { Upper Basin }\end{array}$ \\
\multicolumn{1}{|c}{} \\
\end{tabular}} \\
\hline \multirow{18}{*}{ 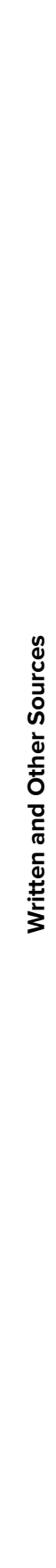 } & $\begin{array}{l}\text { H.W. Hincks, Engineer, to L.M. Holt, Superintendent of Irrigation for the U.S. Indian } \\
\text { Service, March 24, 1914, copy held by author. }\end{array}$ & \\
\hline & $\begin{array}{l}\text { "May Ask U.S. to See That River is Kept Clear: Is Shutting off Indians Salmon Supply," } \\
\text { Evening Herald (Klamath Falls), October 23, } 1914 .\end{array}$ & $\checkmark$ \\
\hline & “New Dam Stops Fish in Klamath," Medford Mail Tribune, October 26, 1914. & $\checkmark$ \\
\hline & $\begin{array}{l}\text { E.B. Meritt, Assistant Commissioner of Indian Affairs, to Supt. Klamath School, } \\
\text { Klamath Agency, August 115, 1916, including handwritten notes by Fred Hendricks, } \\
\text { Klamath Agency, Oregon, filed with 2446-1915-Klamath Agency-115, Central Classified } \\
\text { Files, 1907-1939 [hereafter Klamath Agency Central Classified Files, 1907-1939], RG } \\
75 \text {, Commmission of Indian Affairs, National Archives and Records Administration, } \\
\text { Washington, D.C. [hereafter NARA] }\end{array}$ & $\checkmark$ \\
\hline & $\begin{array}{l}\text { H. Wilson, handwritten report on salmon fishing on the Klamath Indian Reservation, } \\
\text { 1916, filed with Klamath Agency Central Classified Files, 1907-1939, RG 75, NARA. }\end{array}$ & $\checkmark$ \\
\hline & $\begin{array}{l}\text { California Fish and Game Commission, Twenty-Fifth Biennial Report: For the Years } \\
\text { 1916-1918 (Sacramento: State Printing Office, 1918), } 38 .\end{array}$ & \\
\hline & $\begin{array}{l}\text { E.B. Meritt, Assistant Commissioner of Indian Affairs, to Oregon Fish and Game } \\
\text { Commission, August 14, 1918, filed with Klamath Agency Central Classified Files, 1907- } \\
\text { 1939, RG 75, NARA. }\end{array}$ & $\checkmark$ \\
\hline & $\begin{array}{l}\text { California Fish and Game Commission, Twenty-Sixth Biennial Report: For the Years } \\
1918-1920 \text { (Sacramento: State Printing Office, 1920), } 25 .\end{array}$ & \\
\hline & $\begin{array}{l}\text { "Sportsmen Get Organization Well Started," Evening Herald (Klamath Falls), January } \\
\text { 10, 1920, p. 1. }\end{array}$ & $\checkmark$ \\
\hline & Holder, Game Fishes of the World. & $\checkmark$ \\
\hline & "Says Fishway over Dam Impractical," Evening Herald, February 16, 1921. & \\
\hline & "Sportsmen Urge Many Improvements," Evening Herald, July 8, 1921, 1-2. & \\
\hline & $\begin{array}{l}\text { Edward Curtis, The North American Indian: Being a Series of Volumes Picturing and } \\
\text { Describing the Indians of the United States, the Dominion of Canada, and Alaska } \\
\text { (New York: Johnson Reprint Corporation, 1978). }\end{array}$ & $\checkmark$ \\
\hline & $\begin{array}{l}\text { L. Holt to Commissioner of Indian Affairs, July 7, } 1925 \text { (regarding fishways at the Modoc } \\
\text { Point diversion dam), copy held by author. }\end{array}$ & $\checkmark$ \\
\hline & J. Snyder, "Salmon of the Klamath River California," Fish Bulletin 34 (1931). & $\checkmark$ \\
\hline & $\begin{array}{l}\text { B. Courtright, "Memorandum-Salmon on the Klamath," January 16, 1941, file } 3 \text { of } 3 \text { of a a } \\
\text { series of files titled, "419.4 COPCO Case, } 1940-1946, \text { ". Decimal Correspondence, Klamath } \\
\text { Agency, RG } 75 \text {, National Archives and Records Administration, Pacific Alaska Region, } \\
\text { Seattle, Washington [hereatter NARA Pacific Alaska Region]. }\end{array}$ & $\checkmark$ \\
\hline & $\begin{array}{l}\text { B. Courtright to Kenneth R. L. Simmons, August 13, 1941, file } 3 \text { of } 3 \text { of a series of files } \\
\text { titled, "419.4 COPCO Case, 1940-1946," Decimal Correspondence, Klamath Agency, RG } \\
75 \text {, NARA Pacific Alaska Region. }\end{array}$ & $\checkmark$ \\
\hline & $\begin{array}{l}\text { Rachel Applegate Good, History of Klamath County Oregon: Its Resources and Its } \\
\text { People (Klamath Falls: Klamath County Historical Society, 1941). }\end{array}$ & $\checkmark$ \\
\hline
\end{tabular}




\begin{tabular}{|c|c|c|}
\hline \multicolumn{2}{|c|}{ DOCUMENTATION } & \multirow{2}{*}{ 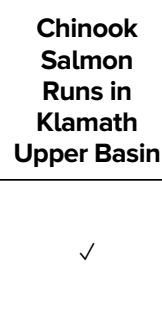 } \\
\hline \multirow{17}{*}{ 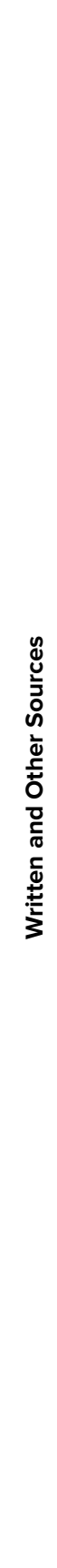 } & $\begin{array}{l}\text { K. Simmons to B.G. Courtright, Superintendent, Klamath Indian Agency, Klamath } \\
\text { Agency, Oregon, August 21, 1941, file } 3 \text { of } 3 \text { of a series of files titled, "419.4 COPCO } \\
\text { Case, 1940-1946," Decimal Correspondence, Klamath Agency, RG 75, NARA Pacific } \\
\text { Alaska Region. }\end{array}$ & \\
\hline & $\begin{array}{l}\text { K.R.L. Simmons, District Counsel, United States Department of the Interior, Office of } \\
\text { Indian Affairs, Field Service to Matt Ryckman, Oregon Superintendent of Fisheries, } \\
\text { July 28, 1941, Copco Case File, box 109, Decimal Correspondence, Klamath Agency, } \\
\text { RG 75, NARA Pacific Alaska. }\end{array}$ & $\checkmark$ \\
\hline & $\begin{array}{l}\text { W. Knight to B.G. Courtright, map encl., December 12, 1941, Copco Case File, Decimal } \\
\text { Correspondence, box 109, Klamath Agency, RG 75, NARA Pacific Alaska Region. }\end{array}$ & \\
\hline & $\begin{array}{l}\text { A. Moore, Outline of a Wildlife Management Plan for the Klamath Indian Reservation, } \\
\text { U.S. Fish and Wildlife Service, } 1943 \text {. }\end{array}$ & $\checkmark$ \\
\hline & $\begin{array}{l}\text { F. Hewes, "Aboriginal Use of Fishery Resources in Northwestern North America," } \\
\text { (Ph.D. diss.: University of California, 1947.) }\end{array}$ & \\
\hline & $\begin{array}{l}\text { G. Duncan, "Klamath Falls to Pokegama by the Old Stage and Freight Stations," } \\
\text { Yearbook 1948, Siskiyou County Historical Society 1:3 (1948): } 45 .\end{array}$ & \\
\hline & $\begin{array}{l}\text { "As Told to Me ... by Rod Frain," October 24, } 1948 \text { interview in Klamath Echoes 1:3 } \\
\text { (1966): 7-8. }\end{array}$ & $\checkmark$ \\
\hline & $\begin{array}{l}\text { “As Told to Me ... by George Masten Miller," February 28, 1948, oral history recorded } \\
\text { by Devere Helfrich, Klamath Echoes 1:1 (1964): 13-17. }\end{array}$ & $\checkmark$ \\
\hline & Wales, Management of King Salmon Spawning in the Klamath River, Siskiyou County. & \\
\hline & $\begin{array}{l}\text { J. Wales and M. Coots, Second Report on the Effect of the Klamath River Water } \\
\text { Fluctuations upon Salmonid Fishes, memo from the California Department of Fish and } \\
\text { Game District Fisheries Biologist to the Bureau of Fish Conservation, } 1950 \text {. }\end{array}$ & \\
\hline & $\begin{array}{l}\text { M. Coots and J. Wales, King Salmon Activity in Jenny Creek and the Old Klamath River } \\
\text { Channel between the Forebay Dam and Copco \#2 Plant, California Department of } \\
\text { Fish and Game, October 29, } 1952 \text {. }\end{array}$ & \\
\hline & $\begin{array}{l}\text { M. Coots, King Salmon Count-Klamath River, Klamathon Racks-Siskiyou County, } \\
\text { Inland Fisheries Branch, California Department of Fish and Game, } 1953 .\end{array}$ & \\
\hline & $\begin{array}{l}\text { A. Kroeber, Handbook of the Indians of California (Berkeley: California Book Company, } \\
\text { Ltd., 1953). }\end{array}$ & \\
\hline & $\begin{array}{l}\text { M. Coots, Efficiency of King Salmon Spawning in Fall Creek, Siskiyou County- } \\
\text { Progress Report for 1953-54, California Department of Fish and Game, Inland Fisheries } \\
\text { Branch, } 1954 .\end{array}$ & \\
\hline & $\begin{array}{l}\text { M. Coots, Klamath River } 1954 \text { King Salmon Count, Klamathon Racks, Siskiyou County, } \\
\text { and Some Notes on Marked King Salmon Recoveries in the Upper Klamath River, } \\
\text { Inland Fisheries Branch, California Department of Fish and Game, } 1954 .\end{array}$ & \\
\hline & $\begin{array}{l}\text { USDI Fish and Wildlife Service, A Special Report on Fish and Wildlife Resources } \\
\text { Affected by Developments Proposed for the Upper Klamath Basin, Oregon and } \\
\text { California, United States Department of the Interior, Fish and Wildlife Service, Portland } \\
\text { Oregon, 1954. }\end{array}$ & $\checkmark$ \\
\hline & $\begin{array}{l}\text { E. Hughes and G. Weber, Report on North Coast Salmon Carcass Recovery Work- } \\
1955 \text {, California Department of Fish and Game, } 1955 .\end{array}$ & \\
\hline
\end{tabular}

\begin{tabular}{|c|c|c|}
\hline \multicolumn{2}{|c|}{ DOCUMENTATION } & $\begin{array}{l}\text { Chinook } \\
\text { Salmon } \\
\text { Runs in }\end{array}$ \\
\hline \multirow{19}{*}{ 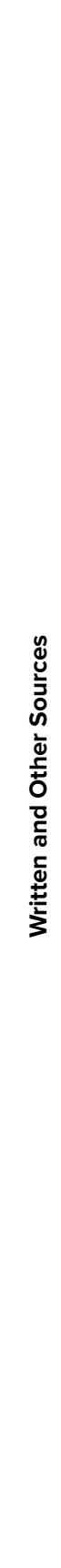 } & $\begin{array}{l}\text { G. Wright, Tidbits of Greensprings and Klamath River Canyon History, 1957, typescript } \\
\text { at Bureau of Land Management Klamath Falls Resource Area, Lakeview District, } \\
\text { Klamath Falls, Oregon. }\end{array}$ & \\
\hline & $\begin{array}{l}\text { M. Coots, Klamath River } 1956 \text { King Salmon Count, Klamathon Racks, Siskiyou County, } \\
\text { California Department of Fish and Game Inland Fisheries 1958, Administrative Report } \\
58-9 \text {. }\end{array}$ & \\
\hline & $\begin{array}{l}\text { Klamath County Pomona Grange, Resolution Favoring the Building of a Fish Ladder or } \\
\text { Other Means for the Passing of Salmon and Other Fish to the Waterways of Klamath } \\
\text { County, 1958, California Department of Fish and Game Executive/Legal Litigation Files, } \\
\text { Copco Case, no. 2001-09-35, California State Archives, Sacramento, California. }\end{array}$ & $\checkmark$ \\
\hline & $\begin{array}{l}\text { Affidavit of James Riley for The People of the State of California v. The California } \\
\text { Oregon Power Company, No. } 13995 \text { (State of California, 1959). }\end{array}$ & \\
\hline & $\begin{array}{l}\text { California Senate, Fact Finding Committee on Natural Resources, Iron Gate Dam: Its } \\
\text { Effect on the Klamath River Fisheries, Yreka, California, } 1961 .\end{array}$ & \\
\hline & W. Wright, "Biography of Robert Whittle," 1962, Siskiyou County Historical Society. & \\
\hline & $\begin{array}{l}\text { Federal Energy Regulatory Commission, Opinion and Order for Petition to Require } \\
\text { Licensee to Construct, Operate, and Maintain a Fish Hatchery, Amending License, } \\
\text { and Directing Revised Filings, Opinion No. 381, (Washington D.C., March 14, 1963). }\end{array}$ & \\
\hline & $\begin{array}{l}\text { V. Ray, Primitive Pragmatists: The Modoc Indians of California (Seattle, Washington: } \\
\text { University of Washington Press, 1963). }\end{array}$ & $\checkmark$ \\
\hline & Devere Helfrich, “The First Boats," Klamath Echoes 1:2 (1965). & $\checkmark$ \\
\hline & $\begin{array}{l}\text { "The History of Klamath Hot Springs Written by Alice Hessig for the } 1965 \text { Siskiyou } \\
\text { Pioneer," Klamath Echoes, } 1977 .\end{array}$ & \\
\hline & $\begin{array}{l}\text { Ray Telford, age 83, longtime Klamath Falls resident, interview by F. Landrum, } \\
\text { November 18, 1965, on CD, Francis S. and Patricia L. Landrum Collection, Shaw } \\
\text { Historical Library, Oregon Institute of Technology, Klamath Falls. }\end{array}$ & $\checkmark$ \\
\hline & T. Stern, The Klamath Tribe (Seattle: University of Washington Press, 1965). & $\checkmark$ \\
\hline & $\begin{array}{l}\text { "Klamath Salmon Report Ready, Meeting Called for Tuesday," Klamath Herald and } \\
\text { News, September 25, 1966, p. 1-A. }\end{array}$ & $\checkmark$ \\
\hline & F. Wynne, "Link River. ..," Klamath Echoes, Centennial Issue 1:4 (1967): 15-16. & $\checkmark$ \\
\hline & $\begin{array}{l}\text { C. Howe, Ancient Tribes of the Klamath Country (Portland, Ore.: Binfords and Mort, } \\
\text { 1968). }\end{array}$ & $\checkmark$ \\
\hline & $\begin{array}{l}\text { C. Lorenz, “The Time of My Life," in Klamath County Museum Research Papers, vol. } 4 \text {, } \\
\text { ed. C. William Burk, (Klamath Falls, Ore.: Klamath County Museum, 1969), 114. }\end{array}$ & $\checkmark$ \\
\hline & $\begin{array}{l}\text { Devere Helfrich, "Keno and Vicinity," Klamath Echoes, Merril-Keno Issue 1:7 (1969): } \\
\text { 47-50. }\end{array}$ & $\checkmark$ \\
\hline & $\begin{array}{l}\text { Earl Leitritz, A History of California's Fish Hatcheries 1870-1960, California Department } \\
\text { of Fish and Game Fish Bulletin 150, Inland Fisheries Branch, State of California, } \\
\text { Department of Fish and Game, 1970. }\end{array}$ & \\
\hline & $\begin{array}{l}\text { "Mrs. Louella O.T. Anderson," Klamath Echoes, Sprague River-Bly Issue 1:12 (1974): } \\
\text { 75-76. }\end{array}$ & $\checkmark$ \\
\hline
\end{tabular}

Hamilton et al., Persistence and Characteristics of Chinook Salmon Migrations 


\begin{tabular}{|c|c|c|}
\hline \multicolumn{2}{|c|}{ DOCUMENTATION } & \multirow{2}{*}{$\begin{array}{c}\text { Chinook } \\
\text { Salmon } \\
\text { Runs in } \\
\text { Klamath } \\
\text { Upper Basin } \\
\end{array}$} \\
\hline \multirow{17}{*}{ 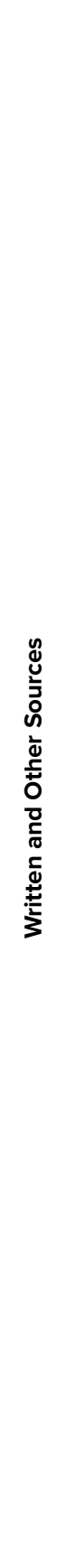 } & $\begin{array}{l}\text { Alice Overton Hessig, Looking Back: The California-Oregon Stage Road from Ager, } \\
\text { California to Topsy, Oregon (Carson City, Nev:: Printers, Inc., 1979). }\end{array}$ & \\
\hline & $\begin{array}{l}\text { J. Mack, “Archaelogical Investigation of the Salt Cave Locality: Subsistence Uniformity } \\
\text { and Cultural Diversity along the Klamath River Oregon," (Ph.D. diss: University of } \\
\text { Oregon, 1978). }\end{array}$ & \\
\hline & E. Moore, Western Echoes (Klamath Falls: Paul Tremaine Publishing, 1981). & $\checkmark$ \\
\hline & $\begin{array}{l}\text { Beak Consultants Inc., Application for License Salt Caves Hydroelectric Project- } \\
\text { Project No. 3313, Report of Beak Consultants to the City of Klamath Falls, Oregon for } \\
\text { submittal to the Federal Energy Regulatory Commission, } 1985 \text {. }\end{array}$ & \\
\hline & $\begin{array}{l}\text { California Department of Fish and Game, Status and Management of Spring-Run } \\
\text { Chinook Salmon, Inland Fisheries Division, } 1990 .\end{array}$ & $\checkmark$ \\
\hline & $\begin{array}{l}\text { D. Theodoratus, M. Ashman, H. McCarthy, D. Genetti, Klamath River Canyon Ethnology } \\
\text { Study. Prepared by Theodoratus Cultural Research, Inc., Fair Oaks, California for } \\
\text { Biosystems Analysis, Inc., Santa Cruz, California, United States Department of the } \\
\text { Interior, Bureau of Land Management, Lakeview District Office, Lakeview, Oregon, } 1990 .\end{array}$ & $\checkmark$ \\
\hline & J. Spindor, Yulalona: A Report on the Link River, 1993, Klamath County Museum. & $\checkmark$ \\
\hline & $\begin{array}{l}\text { Alice Isobel High, "History of Alice Isobell Spencer High, of Ashland (Now Deceased)," } \\
\text { photo of typescript, "Spencer Creek" file, Bureau of Land Management, Klamath Falls } \\
\text { Resource Area, Lakeview District, Klamath Falls, Oregon. }\end{array}$ & \\
\hline & $\begin{array}{l}\text { T. Stern, "Klamath and Modoc," in Handbook of North American Indians, vol. 12, } \\
\text { (Washington, D.C.: Smithsonian Institution, 1998), } 448 .\end{array}$ & $\checkmark$ \\
\hline & $\begin{array}{l}\text { W. Sturtevant, Handbook of North American Indians, vol. 12. (Washington, D.C.: } \\
\text { Smithsonian Institution, 1998). }\end{array}$ & $\checkmark$ \\
\hline & $\begin{array}{l}\text { L.W. Powers, ed., A River Never the Same: A History of Water in the Klamath Basin } \\
\text { (Klamath Falls: Shaw Historical Library, 1999.) }\end{array}$ & $\checkmark$ \\
\hline & $\begin{array}{l}\text { California Department of Fish and Game, Upper Klamath River Wild Trout } \\
\text { Management Plan, } 2000-2004 \text {, Northern California and North Coast Region, Wildlife } \\
\text { and Inland Fisheries Division, } 2000 .\end{array}$ & \\
\hline & $\begin{array}{l}\text { R. Carter to Oregon Department of Fish and Wildlife regarding the History of Spring } \\
\text { Creek, Klamath County, Oregon, March 2001, Oregon Department of Fish and Wildlife, } \\
\text { Klamath Falls Office. }\end{array}$ & $\checkmark$ \\
\hline & $\begin{array}{l}\text { D. Deur, Final Report Traditional Cultural Properties and Sensitive Resource Study: } \\
\text { Klamath Hydroelectric Project FERC Relicensing Documentation, Report to the } \\
\text { Klamath Tribes, 2003. }\end{array}$ & $\checkmark$ \\
\hline & $\begin{array}{l}\text { Stephen Dow Beckham, Historical Landscape Overview of the Upper Klamath River } \\
\text { Canyon of Oregon and California, Cultural Resource Series no. 13, U.S. Department of } \\
\text { Interior, Bureau of Land Management, Oregon State Office, Portland, Oregon, 2006. }\end{array}$ & \\
\hline & $\begin{array}{l}\text { Holly Doremus and A. Dan Tarlock, Water War in the Klamath Basin: Macho Law, } \\
\text { Combat Biology, and Dirty Politics (Washington, D.C.: Island Press, 2008). }\end{array}$ & $\checkmark$ \\
\hline & $\begin{array}{l}\text { V. Butler, A.E. Stevenson, J.A. Miller, D.Y. Yang, C.F. Speller, N. Misarti, The Use of } \\
\text { Archaeological Fish Remains to Establish Pre-Development Salmonid Biogeography } \\
\text { in the Upper Klamath Basin, Final Report, Portland State University Department of } \\
\text { Anthropology, Portland, Oregon, 2010. }\end{array}$ & $\checkmark$ \\
\hline
\end{tabular}

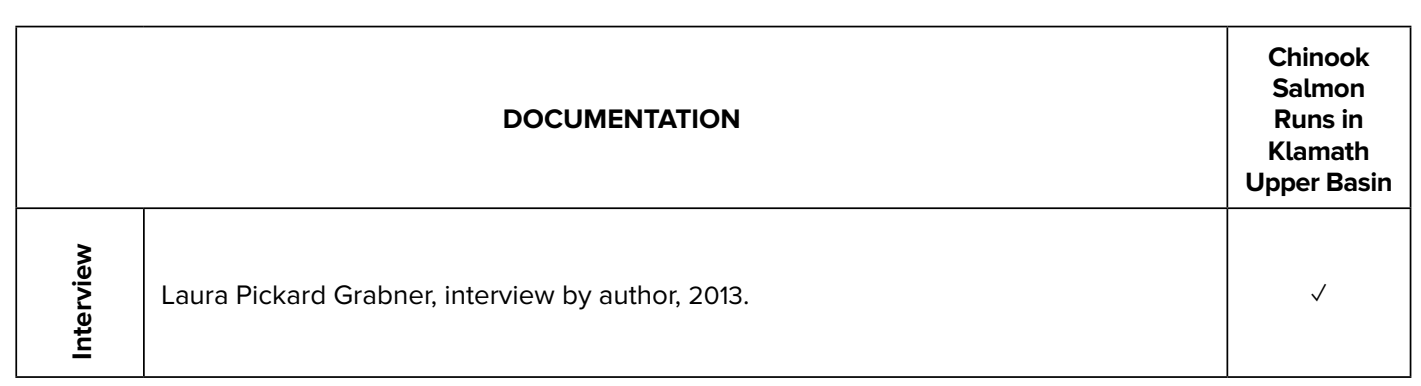

TABLE 2. ACCOUNTS OF CHINOOK SALMON

NON-ABUNDANCE/ABUNDANCE UPSTREAM FROM IRON GATE DAM SITE

\begin{tabular}{|c|c|c|c|}
\hline \multicolumn{2}{|r|}{ ACCOUNT } & \multirow{2}{*}{$\begin{array}{c}\text { DATE } \\
\text { Prior to } \\
\text { dams }\end{array}$} & \multirow{2}{*}{$\begin{array}{l}\text { SOURCE } \\
\text { G. Hewes, Aboriginal Use of Fishery } \\
\text { Resources in Northwestern North } \\
\text { America (Ph.D. diss.: Univ. of Califor- } \\
\text { nia, 1947). }\end{array}$} \\
\hline 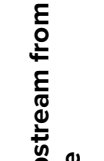 & $\begin{array}{l}\text { ".salmon were available only in the Klamath River } \\
\text { and its tributaries below Copco Marsh, to which a } \\
\text { few ascended." }\end{array}$ & & \\
\hline \multirow{2}{*}{ 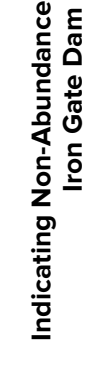 } & $\begin{array}{l}\text { "According to Oregon State Department of Fish and } \\
\text { Wildlife records, before Copco Dam was built... a } \\
\text { hardy few Chinook salmon commonly would ascend } \\
\text { beyond Big Bend Canyon each year-some of them } \\
\text { reaching Upper Klamath Lake and the Williamson } \\
\text { River. However, the major portion of the annual } \\
\text { spawning runs did not pass above the canyon." }\end{array}$ & $\begin{array}{l}\text { Prior to } \\
\text { dams }\end{array}$ & $\begin{array}{l}\text { J. LaLande, First over the Siskiyous: } \\
\text { Peter Skene Ogden's 1826-1827 } \\
\text { Journey through the Oregon-Califor- } \\
\text { nia Borderlands (Portland: OHS Press, } \\
\text { 1987). }\end{array}$ \\
\hline & "A small run enters the Klamath and Umpqua rivers" & $\begin{array}{l}\text { Prior to } \\
\text { dams }\end{array}$ & $\begin{array}{l}\text { Oregon Deptartment of Fisheries, } \\
\text { Annual Report to the Legislative } \\
\text { Assembly 21st Regular Session (1901). }\end{array}$ \\
\hline \multirow{3}{*}{ 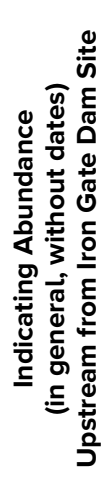 } & $\begin{array}{l}\text { "Salmon, varieties of trout, suckers, and smaller fish } \\
\text { were all to be had in abundance." }\end{array}$ & $\begin{array}{c}\text { Prior to } \\
\text { dams }\end{array}$ & $\begin{array}{l}\text { L. Spier, Klamath Ethnography (Berke- } \\
\text { ley: Univ. of California Press, 1930). }\end{array}$ \\
\hline & $\begin{array}{l}\text { "For years the [Klamath] Indians have spent much } \\
\text { of the spring, summer, and fall months catching } \\
\text { salmon and drying them for winter food, and it is } \\
\text { said that during the last winter some of them actu- } \\
\text { ally suffered because they did not have this supply." }\end{array}$ & $\begin{array}{l}\text { Prior to } \\
\text { dams }\end{array}$ & $\begin{array}{l}\text { "New Dam Stops Fish in Klamath," } \\
\text { Medford Mail Tribune, October } 26, \\
1914 .\end{array}$ \\
\hline & $\begin{array}{l}\text { "The Klamath Indians caught a great many salmon } \\
\text { in Otober every year, which helped materially in } \\
\text { their food supply" }\end{array}$ & $\begin{array}{l}\text { Prior to } \\
\text { dams }\end{array}$ & $\begin{array}{l}\text { H. Wilson, Report on Salmon Fishing } \\
\text { on the Klamath Indian Reservation, } \\
\text { 1916, filed with 2446-1915-Klamath } \\
\text { Agency-115, Central Classified Files, } \\
\text { 1907-1939, Office of Indian Affairs, RG } \\
\text { 75, NARA. }\end{array}$ \\
\hline
\end{tabular}




\begin{tabular}{|c|c|c|c|}
\hline \multicolumn{2}{|c|}{ ACCOUNT } & DATE & SOURCE \\
\hline \multirow{9}{*}{ 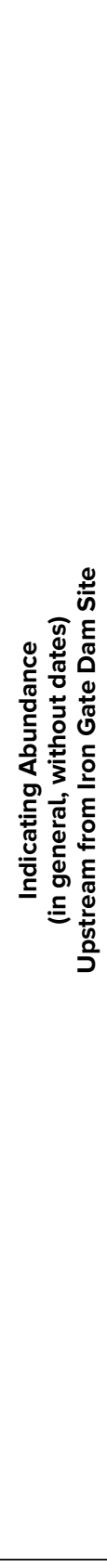 } & $\begin{array}{l}\text { "I have asked a great many Indians and white } \\
\text { people as to the effect of this dam on the fish in the } \\
\text { streams of this locality [the Reservation]. There has } \\
\text { been but one answer and that is that in the past a } \\
\text { great many salmon were caught where the Indians } \\
\text { secured a large part of their sustenance, and since } \\
\text { this dam was begun four years ago there has been } \\
\text { no salmon caught, and I have inquired of white } \\
\text { people who have lived in the country for some time, } \\
\text { and without exception as far as I have heard they } \\
\text { concur absolutely in that report." }\end{array}$ & $\begin{array}{l}\text { Prior to } \\
\text { dams }\end{array}$ & $\begin{array}{l}\text { C. Ashbury to E.B. Meritt, June 7, } \\
\text { 1917, Filed with 2446-1915-Klamath } \\
\text { Agency-115, Central Classified Files, } \\
\text { 1907-1939, Klamath Agency, Oregon, } \\
\text { United States Indian Service, RG 75, } \\
\text { NARA, Washington D.C. }\end{array}$ \\
\hline & $\begin{array}{l}\text { "the largest village... on the banks of the Link } \\
\text { River... was .... the scene of winter fishing } \\
\text { grounds, unexcelled for salmon." }\end{array}$ & $\begin{array}{l}\text { Prior to } \\
\text { dams }\end{array}$ & $\begin{array}{l}\text { Good, History of Klamath County } \\
\text { Oregon. }\end{array}$ \\
\hline & $\begin{array}{l}\text { "No salmon [were] in Klamath Marsh but abundant } \\
\text { elsewhere in area." }\end{array}$ & $\begin{array}{l}\text { Prior to } \\
\text { dams }\end{array}$ & $\begin{array}{l}\text { E. Voegelin, “Culture Element Dis- } \\
\text { tributions, XX: Northeast California," } \\
\text { University of California Anthropologi- } \\
\text { cal Records 7:2 (1942): } 194 .\end{array}$ \\
\hline & $\begin{array}{l}\text { "The older Indians tell me the Sprague was 'full of } \\
\text { salmon.' There were several holes along the river } \\
\text { and fishing was had at these places all day long } \\
\text { and most of the night when torrhes were used. Fish } \\
\text { were taken out by the wagonload." }\end{array}$ & $\begin{array}{l}\text { Prior to } \\
\text { dams }\end{array}$ & $\begin{array}{l}\text { B. Courtright, "Memorandum - } \\
\text { Salmon on the Klamath," January } \\
16,1941 \text {, file } 3 \text { of } 3 \text { of a series of } \\
\text { files titled, " } 419.4 \text { COPCO Case, } \\
1940-1946, \text { " Decimal Correspondence, } \\
\text { Klamath Agency, box 109, BIA, RG 75, } \\
\text { NARA Pacific Alaska Region. }\end{array}$ \\
\hline & $\begin{array}{l}\text { "The blocking of the river marked the end of those } \\
\text { years when salmon teemed in waterways through- } \\
\text { out the basin, at least to the upper limits of the } \\
\text { Sprague River." September } 25,1966\end{array}$ & $\begin{array}{l}\text { Prior to } \\
\text { dams }\end{array}$ & $\begin{array}{l}\text { "Klamath Salmon Report Ready; } \\
\text { Meeting Called for Tuesday," Klamath } \\
\text { Herald and News, September 25, } \\
\text { 1966, p. 1-A. }\end{array}$ \\
\hline & $\begin{array}{l}\text { At Link River "enormous quantities of salmon and } \\
\text { steelhead and mullet were taken each year by the } \\
\text { Indians who dried them for their winter food supply." } \\
\text { (Wynne 1967). }\end{array}$ & $\begin{array}{l}\text { Prior to } \\
\text { dams }\end{array}$ & $\begin{array}{l}\text { F. Wynne, “Link River," Klamath } \\
\text { Echoes 1:4 (1967): 15-16. }\end{array}$ \\
\hline & $\begin{array}{l}\text { "It was here [Fishing (or Moonshine) Falls] that } \\
\text { salmon would 'stack up like cordwood" and were } \\
\text { easily secured by those early fishermen (Indians } \\
\text { and early whites)." }\end{array}$ & $\begin{array}{l}\text { Prior to } \\
\text { dams }\end{array}$ & $\begin{array}{l}\text { D. Helfrich, "Keno and Vicinity," } \\
\text { Klamath Echoes 1:7 (1969) Merril-Keno } \\
\text { Issue: } 47-50 .\end{array}$ \\
\hline & $\begin{array}{l}\text { "the salmon run [Sprague River] was so heavy they } \\
\text { could run between your legs and almost knock } \\
\text { you down." }\end{array}$ & $\begin{array}{l}\text { Prior to } \\
\text { dams }\end{array}$ & $\begin{array}{l}\text { H. Wright, in Lane and Lane Asso- } \\
\text { ciates, The Copco Dams and the } \\
\text { Fisheries of the Klamath Tribe: Report } \\
\text { of Lane and Lane Associates to the } \\
\text { USDI Bureau of Indian Affairs, Port- } \\
\text { land, Oregon, } 1981,61\end{array}$ \\
\hline & $\begin{array}{l}\text { "I remember that salmon used to go up the Sprague } \\
\text { River to Bly. There used to be lots of salmon and } \\
\text { many times I saw Indians fishing at Baking Powder } \\
\text { Grade." }\end{array}$ & $\begin{array}{l}\text { Prior to } \\
\text { dams }\end{array}$ & $\begin{array}{l}\text { G. Duvall, 1946, in Courtright and } \\
\text { Simmons Affidavits 1941-1946, NARA } \\
\text { Pacfific Alaska Region. }\end{array}$ \\
\hline
\end{tabular}

\begin{tabular}{|c|c|c|c|}
\hline \multicolumn{2}{|r|}{ ACCOUNT } & DATE & SOURCE \\
\hline \multirow{7}{*}{ 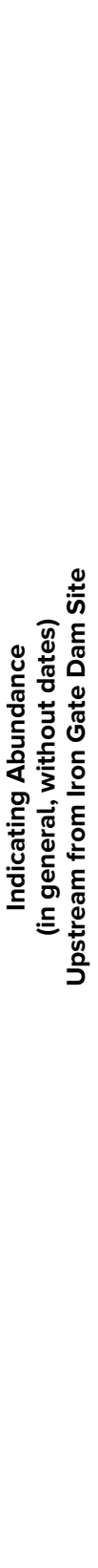 } & $\begin{array}{l}\text { "Mr. Howard stated that his father would drive a } \\
\text { wagon to the crossing (where the Applegate Trail } \\
\text { crosses Spencer Creek) and using a pitchfork, load } \\
\text { it with salmon. The wagon would be so full, the } \\
\text { salmon would flop out going up the hill" (Hinton } \\
\text { pers. comm. } 1995 \text { In USDI Bureau of Land Manage- } \\
\text { ment, USDA Forest Service et al. 1995). }\end{array}$ & $\begin{array}{l}\text { Prior to } \\
\text { dams }\end{array}$ & $\begin{array}{l}\text { USDI BLM, USDA Forest Service, EPA, } \\
\text { and USDI Fish and Wildlife Service, } \\
\text { Spencer Creek Pilot Watershed Anal- } \\
\text { ysis, U.S. Department of the Interior, } \\
\text { BLM, Klamath Falls Field Office, } 1995 .\end{array}$ \\
\hline & $\begin{array}{l}\text { "I remember fording Spencer Creek; about } 20 \text { miles } \\
{[32 \text { kilometers] below Klamath Falls, and the salmon }} \\
\text { were so thick the horses became frightened." }\end{array}$ & $\begin{array}{l}\text { Prior to } \\
\text { dams }\end{array}$ & $\begin{array}{l}\text { H.H. Cole, 1946, in B. Courtright and } \\
\text { K. Simmons, Affidavits 1941-1946 } \\
\text { regarding historical salmon fishery } \\
\text { upstream from Copco } 1 \text { Dam, U.S. } \\
\text { Department of the Interior, Office } \\
\text { of Indian of Indian Affairs, Klamath } \\
\text { Agency, Record Group 75, Decimal } \\
\text { Correspondence, box 109, Copco } \\
\text { Case File, folders } 1 \text { and 3, U.S. } \\
\text { Department of the Interior, Office of } \\
\text { Indian Affairs [hereafter Courtright and } \\
\text { Simmons Affidavits 1941-1946], NARA } \\
\text { Pacific Alaska Region. }\end{array}$ \\
\hline & $\begin{array}{l}\text { "I remember the runs of salmon in the north fork of } \\
\text { the Sprague River in the fall and the Indians catch- } \\
\text { ing them. One of the most colorful was one named } \\
\text { "Whiskey John' who used to spear salmon dressed } \\
\text { only in a red undershirt. The Indians caught lots of } \\
\text { salmon and would dry them on racks to provide } \\
\text { food in the winter." }\end{array}$ & $\begin{array}{l}\text { Prior to } \\
\text { dams }\end{array}$ & $\begin{array}{l}\text { C. Schmitz, 1946, in Courtright and } \\
\text { Simmons Affidavits 1941-1946, NARA } \\
\text { Pacfific Alaska Region. }\end{array}$ \\
\hline & $\begin{array}{l}\text { "I saw salmon hurling themselves at this [COPCO } \\
\text { Dam] in thousands and beating their heads in, many } \\
\text { of them had battered their heads completely off } \\
\text { back to the eyes." }\end{array}$ & $\begin{array}{l}\text { Prior to } \\
\text { IGD }\end{array}$ & $\begin{array}{l}\text { W. Knight to B.G. Courtright, letter and } \\
\text { map, December 12, 1941, Copco Case } \\
\text { File, Decimal Correspondence, Box } \\
\text { 109, folders } 1 \text { and 3, Klamath Agency, } \\
\text { BIA, RG 75, NARA Pacific Alaska } \\
\text { Region. }\end{array}$ \\
\hline & $\begin{array}{l}\text { "I would say that the salmon fish obtained by these } \\
\text { Indians during those years provided one-half of the } \\
\text { food consumed by them." }\end{array}$ & $\begin{array}{l}\text { Prior to } \\
\text { dams }\end{array}$ & $\begin{array}{l}\text { D. Skeen in Lane and Lane Associ- } \\
\text { ates, The Copco Dams and the } \\
\text { Fisheries of the Klamath Tribe: Report } \\
\text { of Lane and Lane Associates to the } \\
\text { USDI Bureau of Indian Affairs, Port- } \\
\text { land, Oregon, 1981. }\end{array}$ \\
\hline & $\begin{array}{l}\text { "We Indians depended to a great extent on the } \\
\text { salmon for our food supply. I would state that about } \\
\text { one-third to a half of our food supply was provided } \\
\text { by the salmon." }\end{array}$ & $\begin{array}{l}\text { Prior to } \\
\text { dams }\end{array}$ & R. David in Ibid. \\
\hline & $\begin{array}{l}\text { "The salmon provided the Indians with about one- } \\
\text { third of their food supply each year." }\end{array}$ & $\begin{array}{l}\text { Prior to } \\
\text { dams }\end{array}$ & D. Chocktoot in Ibid. \\
\hline
\end{tabular}




\begin{tabular}{|c|c|c|c|}
\hline \multicolumn{2}{|r|}{ ACCOUNT } & \multirow{2}{*}{$\begin{array}{c}\text { DATE } \\
\begin{array}{c}\text { Prior to } \\
\text { dams }\end{array}\end{array}$} & \multirow[t]{2}{*}{ SOURCE } \\
\hline \multirow{4}{*}{ 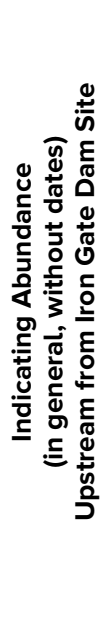 } & $\begin{array}{l}\text { "I would estimate that } 1 / 6 \text { of the subsistence of all } \\
\text { of the Indians residing on the Klamath river between } \\
1890 \text { and } 1909 \text { was provided by the salmon fish } \\
\text { caught in the reservation streams..." }\end{array}$ & & \\
\hline & "Speared salmon, lots of salmon dried." & $\begin{array}{c}\text { Prior to } \\
\text { dams }\end{array}$ & I. Mose in Ibid. \\
\hline & $\begin{array}{l}\text { "Recalled salmon in Spencer Creek, } 20 \text { miles below } \\
\text { Klamath Falls, so thick that they frightened the } \\
\text { horses fording the creek." }\end{array}$ & $\begin{array}{c}\text { Prior to } \\
\text { dams }\end{array}$ & H. Ogle in Ibid. \\
\hline & $\begin{array}{l}\text { Natural Obstructions - Keno Falls: These natural } \\
\text { falls have been a detriment to the fishing industry } \\
\text { on the Klamath River for years past inasmuch as } \\
\text { large numbers of salmon and other fish would } \\
\text { congregate in the pools below the falls and injure } \\
\text { themselves, if not kill themselves outright, trying to } \\
\text { surmount the obstruction. }\end{array}$ & $\begin{array}{l}\text { Prior to } \\
\text { dams }\end{array}$ & $\begin{array}{l}\text { Oregon Dept. of Fisheries, Report } \\
\text { of the Master Fish Warden. Biennial } \\
\text { Report of the Det.t of Fisheries of the } \\
\text { State of Oregon: Natural Obstruc- } \\
\text { tions - Keno Falls, Salem, Oregon, } \\
\text { 1911, p. } 40 .\end{array}$ \\
\hline \multirow{6}{*}{ 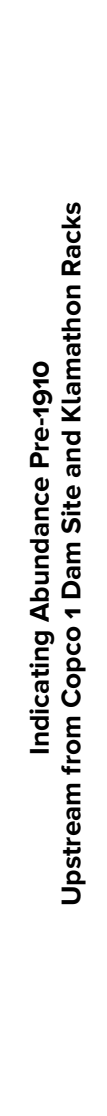 } & $\begin{array}{l}\text { "Up this [Klamath] river the salmon crowd in great } \\
\text { numbers to the lake [Upper Klamath Lake]..." }\end{array}$ & 1846 & $\begin{array}{l}\text { J.C. Frémont, Narratives of Explo- } \\
\text { ration and Adventure (Longmans, } \\
\text { Green, and Co., Inc., 1956). }\end{array}$ \\
\hline & $\begin{array}{l}\text { "Robert Whittle, about 1865, annually for several } \\
\text { years came up the Klamath River [to Keno, Oregon] } \\
\text { from Yreka to catch salmon, salmon trout, and sil- } \\
\text { versides to sell in Yreka." }\end{array}$ & 1865 & $\begin{array}{l}\text { G. Duncan, "Klamath Falls to Poke- } \\
\text { gama by the Old Stage and Freight } \\
\text { Stations," Yearbook, Siskiyou County } \\
\text { Historical Society 1:3 (1948): } 45 \text {. }\end{array}$ \\
\hline & $\begin{array}{l}\text { "The lake [Upper Klamath Lake] abounds in both } \\
\text { salmon and trout, a source of pleasure and profit } \\
\text { to our citizens, and especially to Poor Lo [Indians], } \\
\text { who takes them out in the spring by the wagon load, } \\
\text { and piles them up like cordwood to dry in the sun } \\
\text { for his winter's food." }\end{array}$ & 1884 & Linkville Star, May 10, 1884. \\
\hline & $\begin{array}{l}\text { "The lakes and streams of this country literally } \\
\text { team with 'speckled trout' of the following variet- } \\
\text { ies... . salmon..." }\end{array}$ & 1888 & $\begin{array}{l}\text { The Great Klamath Basin and } \\
\text { Klamath County (Linkville: Klamath } \\
\text { County Museum, 1888), } 2 .\end{array}$ \\
\hline & $\begin{array}{l}\text { "The Indians obtained a large part of their liveli- } \\
\text { hood from the salmon fish they caught... I would } \\
\text { say that approximately 3,000 pounds [1361 kg] } \\
\text { of salmon fish were taken out at Baking Powder } \\
\text { Grade[Sprague River] each day for go days." Victor } \\
\text { Nelson, member of the Klamath Tribes. }\end{array}$ & $\begin{array}{c}1888- \\
1909\end{array}$ & $\begin{array}{l}\text { V. Nelson, in Lane and Lane Assoc., } \\
\text { The Copco Dams and the Fisheries } \\
\text { of the Klamath Tribe; K. Simmons, } \\
\text { Proposed Action for Injunction and } \\
\text { Damages: U.S. v. California Oregon } \\
\text { Power Company (Washington, D.C., } \\
\text { 1942). }\end{array}$ \\
\hline & $\begin{array}{l}\text { "There were ten of us in the family and I supplied } \\
\text { the salmon for the use of my family. What salmon I } \\
\text { caught I did not need, my family would give to their } \\
\text { friends. I would take between } 300 \text { to } 400 \text { salmon } \\
\text { out of the reservation streams each and every fall } \\
\text { during the salmon runs." James Johnson, born 1887, } \\
\text { member of the Klamath Tribes. }\end{array}$ & $\begin{array}{c}1888- \\
1909\end{array}$ & $\begin{array}{l}\text { J. Johnson, in Lane and Lane Assoc, } \\
\text { The Copco Dams and the Fisher- } \\
\text { ies of the Klamath Tribe; Simmons, } \\
\text { Proposed Action for Injunction and } \\
\text { Damages. }\end{array}$ \\
\hline
\end{tabular}

\begin{tabular}{|c|c|c|c|}
\hline \multicolumn{2}{|r|}{ ACCOUNT } & DATE & SOURCE \\
\hline \multirow{9}{*}{ 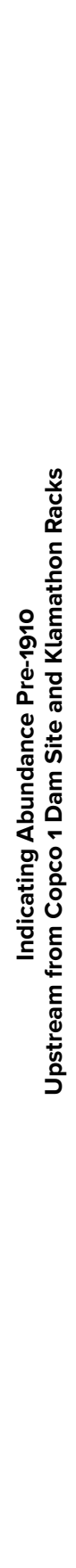 } & $\begin{array}{l}\text { "I know from my own knowledge... The salmon } \\
\text { taken out... provided approximately one-half of } \\
\text { the food that all of the Klamath Indians used from } \\
1898 \text { to the time when the fish were stopped by the } \\
\text { dam of the California Oregon Power Company in } \\
1910 . " \text { Delford Lang, member of the Klamath Tribes. }\end{array}$ & $\begin{array}{c}1898 \text { to } \\
1910\end{array}$ & $\begin{array}{l}\text { D. Lang in Lane and Lane Assoc, The } \\
\text { Copco Dams and the Fisheries of the } \\
\text { Klamath Tribe. }\end{array}$ \\
\hline & $\begin{array}{l}\text { "My husband fished salmon in all the fishing spots } \\
\text { at Sprague River... He would take between } 3-400 \\
\text { salmon a year." Bertha Lotches, born 1889, member } \\
\text { of the Klamath Tribes }\end{array}$ & $\begin{array}{c}1901 \\
\text { (until } \\
\text { runs } \\
\text { stopped) }\end{array}$ & B. Lotches in Ibid. \\
\hline & $\begin{array}{l}\text { "Salmon and lake trout are now being caught in } \\
\text { great abundance." }\end{array}$ & 1901 & $\begin{array}{l}\text { Local News, Klamath Republican, } \\
\text { February 21, } 1901 .\end{array}$ \\
\hline & $\begin{array}{l}\text { "Roy Wright has caught four large salmon from } \\
\text { the river at this place [Link River] the last week. He } \\
\text { pulled one out yesterday that weighed } 25 \text { pounds } \\
\text { [11.3 kg]. Lots of them are in the river, he says." }\end{array}$ & 1902 & $\begin{array}{l}\text { Local News, Klamath Republican, } \\
\text { September } 18,1902 .\end{array}$ \\
\hline & $\begin{array}{l}\text { "It is reported that the fish ladder at Klamathon is } \\
\text { a poor arrangement and has not accommodated } \\
\text { the salmon during their run, thousands have been } \\
\text { killed in attempting to go over it ... If a sufficient } \\
\text { ladder were provided there would be an abundance } \\
\text { of salmon here." }\end{array}$ & 1902 & $\begin{array}{l}\text { Local News, Klamath Republican, } \\
\text { October 16, } 1902 .\end{array}$ \\
\hline & $\begin{array}{l}\text { "I would personally salt down } 400 \text { or } 500 \text { pounds } \\
\text { of fish following each salmon runs while I was here } \\
\text { on the reservation... After } 1902 \text { I fished every } \\
\text { year during each salmon run until the spring of } \\
1909 \text {... During each of those year following } 1902 \\
\text { the salmon runs were about the same. There were } \\
\text { sufficient salmon running in the streams for all of } \\
\text { the Indians to obtain the salmon they needed in } \\
\text { sufficient quantity." }\end{array}$ & 1902 & $\begin{array}{l}\text { J. Cole, in Lane and Lane Assoc., The } \\
\text { Copco Dams and the Fisheries of the } \\
\text { Klamath Tribe. }\end{array}$ \\
\hline & $\begin{array}{l}\text { "salmon were running in the Klamath River at that } \\
\text { time and several loads had been brought to town } \\
\text { [Klamath Falls] from downriver" }\end{array}$ & 1903 & $\begin{array}{l}\text { "Local News-The Salmon Are } \\
\text { Now Running in the Klamath River," } \\
\text { Klamath Republican, September 10, } \\
\text { 1903. } \\
\end{array}$ \\
\hline & $\begin{array}{l}\text { "I remember distinctly during } 1904 \text { on several occa- } \\
\text { sions I would drive a spring wagon to the fishing } \\
\text { holes and fish all night with the Indians getting } \\
\text { sufficient salmon to load this wagon full of salmon } \\
\text { fish. The wagon would hold approximately } 35 \text { to } \\
40 \text { salmon, the salmon varying in weight between } \\
10 \text { and } 40 \text { pounds }[4.5 \text { to } 18.1 \mathrm{~kg} \text {.. There would } \\
\text { sometimes be between } 100 \text { and } 125 \text { Indian fisher- } \\
\text { men spearing fish during these runs. Thousands } \\
\text { of pounds of salmon would be taken out during } \\
\text { heavy runs..." }\end{array}$ & 1904 & $\begin{array}{l}\text { E. Beal in K. Simmons, Proposed } \\
\text { Action for Injunction and Damages: } \\
\text { United States vs California Oregon } \\
\text { Power Company (Washington, D. C.: } \\
\text { United States, 1942). }\end{array}$ \\
\hline & $\begin{array}{l}\text { "... There are millions of the fish [salmon] below } \\
\text { the falls near Keno...." }\end{array}$ & 1908 & $\begin{array}{l}\text { "Millions of Salmon: Cannot Reach } \\
\text { the Lake on Account of Rocks in River } \\
\text { at Keno," Klamath Evening Herald, } \\
\text { September 24, 1908, p. } 1 .\end{array}$ \\
\hline
\end{tabular}




\begin{tabular}{|c|c|c|c|}
\hline \multicolumn{2}{|r|}{ ACCOUNT } & \multirow{2}{*}{$\begin{array}{c}\text { DATE } \\
1909\end{array}$} & \multirow{2}{*}{$\begin{array}{l}\text { SOURCE } \\
\text { "Where Shovel Creek Reaches } \\
\text { Klamath: The Famous Fishing and } \\
\text { Hunting Ground of Northern Cali- } \\
\text { fornia," San Francisco Call, June 27, } \\
\text { 1909. }\end{array}$} \\
\hline 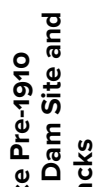 & $\begin{array}{l}\text { "The salmon run up the river and go up Shovel } \\
\text { Creek in such numbers as to be almost beyond } \\
\text { belief. It is a fact that at narrow points in the river } \\
\text { the salmon sometimes crowd each other out upon } \\
\text { the bank." }\end{array}$ & & \\
\hline 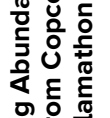 & $\begin{array}{l}\text { "Sometimes the salmon crowd narrow Shovel Creek } \\
\text { until it would appear possible to use pitchforks and } \\
\text { supply a cannery." }\end{array}$ & 1909 & $\begin{array}{l}\text { R. Steele, "The Big One up Shovel } \\
\text { Creek (Illustrated)," Western Field, } \\
\text { October 1909, p. 49-56. }\end{array}$ \\
\hline 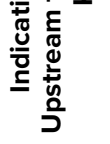 & $\begin{array}{l}\text { "Salmon are still running in large numbers [at Link } \\
\text { River]" }\end{array}$ & 1909 & $\begin{array}{l}\text { "Great Sport on the River: Trout Are } \\
\text { Plentiful and Easy to Catch-Salmon } \\
\text { Are still Running," Klamath Republi- } \\
\text { can, October } 14 \text { 1909, p. } 1 .\end{array}$ \\
\hline \multirow{6}{*}{ 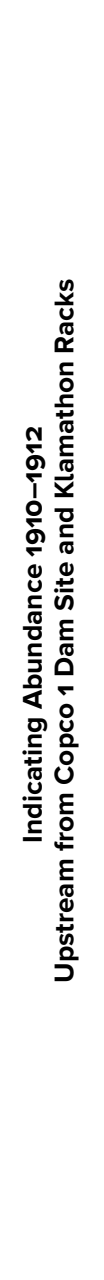 } & $\begin{array}{l}\text { "thousands of salmon are beating their lives out in } \\
\text { an attempt to scale the falls [Moonshine Falls]. A } \\
\text { fish ladder could be built at a cost not to exceed. . " }\end{array}$ & 1910 & $\begin{array}{l}\text { "Fish Ladder Needed," Sunday } \\
\text { Oregonian, April 10, } 1910 .\end{array}$ \\
\hline & $\begin{array}{l}\text { "Thousands of salmon enter the Klamath River } \\
\text { [in Oregon]... The Klamath County Rod and Gun } \\
\text { Club desires a special provision lifting the protec- } \\
\text { tion from salmon to permit Klamath people to get } \\
\text { at least some benefit from the large salmon runs } \\
\text { here during the Fall and Spring months. Now no } \\
\text { one is allowed to fish other than with hook and line, } \\
\text { and as salmon will not bite a hook this law gives } \\
\text { people here absolutely no benefit from the millions } \\
\text { of salmon in these waters." }\end{array}$ & 1910 & $\begin{array}{l}\text { “Fish Laws Demanded," Morning } \\
\text { Oregonian, December 10, 1910, p. } 3 .\end{array}$ \\
\hline & $\begin{array}{l}\text { "Lakeview - Indians from the Klamath Reservation } \\
\text { are... selling ... some of the finest salmon that } \\
\text { they have ever had brought over to this part of the } \\
\text { country. The fish are running this year in largely } \\
\text { increased numbers, and are of better quality than } \\
\text { usual at this time of the year." }\end{array}$ & 1911 & $\begin{array}{l}\text { "Indian Fishers Sell Fine Wares," } \\
\text { Klamath Evening Herald, October 15, } \\
\text { 1911. }\end{array}$ \\
\hline & $\begin{array}{l}\text { "... one of the Klamath Indians, last week came } \\
\text { over from the Reservation [to Lakeview Oregon] } \\
\text { bringing with him a large load of salmon which were } \\
\text { caught in the Sprague River. It is needless to say } \\
\text { that he found a ready sale for the fish." }\end{array}$ & 1911 & $\begin{array}{l}\text { Lake County Examiner, October } 19, \\
1911 .\end{array}$ \\
\hline & $\begin{array}{l}\text { "Salmon are running in fine style in the Klamath } \\
\text { and Link Rivers and are also ascending Lost River } \\
\text { through the recently opened Diversion Canal. None } \\
\text { have been taken with hook and line as yet, although } \\
\text { a number of fishermen have been whipping Link } \\
\text { River for them." }\end{array}$ & 1912 & $\begin{array}{l}\text { "Salmon Running in Rivers," Portland } \\
\text { Morning Oregonian, September 9, } \\
\text { 1912, p. 3. }\end{array}$ \\
\hline & $\begin{array}{l}\text { "large numbers of salmon are dried, smoked and } \\
\text { salted during this time of the year." }\end{array}$ & $\begin{array}{c}\text { Through } \\
1912\end{array}$ & $\begin{array}{l}\text { "Indians Oppose Salmon Racks at } \\
\text { Hatcheries-Future Supply in Serious } \\
\text { Danger," Klamath Evening Herald, } \\
\text { November } 3,1913, \text { p. } 1 .\end{array}$ \\
\hline
\end{tabular}

TABLE 3: ADDITIONAL DOCUMENTATION OF THE PRESENCE AND EXTENT OF CHINOOK SALMON DISTRIBUTION IN THE KLAMATH RIVER SYSTEM UPSTREAM FROM IRON GATE DAM SINCE HAMILTON ET AL. (2005) PUBLICATION

\begin{tabular}{|c|c|c|c|c|}
\hline SEASON & $\begin{array}{l}\text { WATERSHED } \\
\text { REFERENCEE }\end{array}$ & LOCATION & DATE & SOURCE \\
\hline \multirow[t]{4}{*}{ Winter } & $\begin{array}{l}\text { Klamath Upper Basin (Link } \\
\text { River to Headwaters) }\end{array}$ & Link River & February 21, 1901 & $\begin{array}{l}\text { "Local News: Salmon and } \\
\text { lake trout now being caught } \\
\text { in great abundance," Klamath } \\
\text { Republican, February 21, 1901. }\end{array}$ \\
\hline & Klamath Upper Basin & Link River & March 21, 1901 & $\begin{array}{l}\text { Article on fish runs from the } \\
\text { March 21, } 1901 \text { edition of the } \\
\text { Klamath Republican, reprinted } \\
\text { in the Klamath Echoes, } 1965 .\end{array}$ \\
\hline & Klamath Upper Basin & Link River & Winter & $\begin{array}{l}\text { Good, History of Klamath } \\
\text { County Oregon. }\end{array}$ \\
\hline & Klamath Upper Basin & Link River & March & $\begin{array}{l}\text { Fortune, et al, A study to } \\
\text { Determine the Feasibility of } \\
\text { Establishing Salmon. }\end{array}$ \\
\hline \multirow[t]{10}{*}{ Spring } & IGD to Keno & $\begin{array}{l}\text { Upper Klamath } \\
\text { River Canyon }\end{array}$ & April & $\begin{array}{l}\text { Theodoratatus, et al., Klamath } \\
\text { River Canyon Ethnology Study. }\end{array}$ \\
\hline & $\begin{array}{l}\text { IGD to Keno (downstream } \\
\text { from Link River) }\end{array}$ & $\begin{array}{l}\text { "Moonshine } \\
\text { Falls" }\end{array}$ & April 12, 1910 & $\begin{array}{l}\text { "Fish Ladder Needed," } \\
\text { Oregonian, April 10, 1910; “State } \\
\text { News," Daily Capitol Journal, } \\
\text { April 12, 1910. }\end{array}$ \\
\hline & Klamath Upper Basin & Link River & May 6, 1846 & $\begin{array}{l}\text { Frémont, Narratives of } \\
\text { Exploration and Adventure }\end{array}$ \\
\hline & Klamath Upper Basin & Link River & May 9, 1846 & $\begin{array}{l}\text { Frémont in Walker, Bear Flag } \\
\text { Rising. }\end{array}$ \\
\hline & Klamath Upper Basin & Link River & May 10, 1884 & Linkville Star, May 10, 1884. \\
\hline & Klamath Upper Basin & Link River & Spring 1888 & $\begin{array}{l}\text { The Great Klamath Basin and } \\
\text { Klamath County (Linkville: } \\
\text { Klamath County Museum, 1888), }\end{array}$ \\
\hline & Klamath Upper Basin & $\begin{array}{l}\text { Link River/ } \\
\text { Klamath Falls }\end{array}$ & Spring 1910 & $\begin{array}{l}\text { "Fish Laws Demanded," Morning } \\
\text { Oregonian, December 10, } 1910 .\end{array}$ \\
\hline & Klamath Upper Basin & UKL tributaries & May-June 1890 & Spier, Klamath Ethnography. \\
\hline & Klamath Upper Basin & UKL tributaries & Spring 1914 & $\begin{array}{l}\text { "New Dam Stops Fish in } \\
\text { Klamath," Medford Tribune, } \\
\text { October 26, 1914. }\end{array}$ \\
\hline & Klamath Upper Basin & UKL tributaries & Spring 1916 & $\begin{array}{l}\text { E.B. Meritt to Supt. Klamath } \\
\text { School, Klamath Agency, } \\
\text { dated August 15, 1916, } \\
\text { 2446-1915-Klamath Agency-115, } \\
\text { RG 75, Central Classified Files, } \\
\text { 1907-1939, NARA. }\end{array}$ \\
\hline
\end{tabular}

Hamilton et al., Persistence and Characteristics of Chinook Salmon Migrations $\quad 365$ 


\begin{tabular}{|c|c|c|c|c|}
\hline SEASON & $\begin{array}{l}\text { WATERSHED } \\
\text { REFERENCE }\end{array}$ & LOCATION & DATE & SOURCE \\
\hline \multirow[t]{4}{*}{ Spring } & Klamath Upper Basin & UKL tributaries & $\begin{array}{l}\text { Spring (two runs } \\
\text { "noted even to } \\
\text { the headwaters") }\end{array}$ & $\begin{array}{l}\text { Snyder, Salmon of the Klamath } \\
\text { River California }\end{array}$ \\
\hline & Klamath Upper Basin & UKL tributaries & May-June & Spier, Klamath Ethnography. \\
\hline & Klamath Upper Basin & UKL tributaries & Spring & Stern, The Klamath Tribe. \\
\hline & Klamath Upper Basin & UKL tributaries & Spring & $\begin{array}{l}\text { Voegelin, "Culture Element } \\
\text { Distributions: XX, Northeast } \\
\text { California," 194 }\end{array}$ \\
\hline \multirow[t]{8}{*}{ Summer } & IGD to Keno & Shovel Creek & July & $\begin{array}{l}\text { "Trout Streams are Beckoning } \\
\text { Angling Hosts," San Francisco } \\
\text { Call, June 4, 1904. }\end{array}$ \\
\hline & IGD to Keno & Shovel Creek & August 10 & $\begin{array}{l}\text { Cumming, "Angling on the } \\
\text { Klamath," 577-583. }\end{array}$ \\
\hline & IGD to Keno & Shovel Creek & $\begin{array}{l}\text { September 8, } \\
1909\end{array}$ & $\begin{array}{l}\text { Judah, “A Siskiyou } \\
\text { vacation,”262-67. }\end{array}$ \\
\hline & IGD to Keno & Shovel Creek & August 29, 1912 & $\begin{array}{l}\text { "Photo - J. Bernard Frisbee of } \\
\text { Berkeley with a limit of rainbow } \\
\text { trout at Klamath Hot Springs," } \\
\text { San Francisco Call, August 29, } \\
1912 .\end{array}$ \\
\hline & Klamath Upper Basin & UKL tributaries & $\begin{array}{l}\text { Summer (starts } \\
\text { about August 15) }\end{array}$ & $\begin{array}{l}\text { E.B. Meritt to Supt. Klamath } \\
\text { School, Klamath Agency, } \\
\text { dated August 15, 1916, } \\
\text { 2446-1915-Klamath Agency-115, } \\
\text { RG 75, Central Classified Files, } \\
\text { 1907-1939, NARA. }\end{array}$ \\
\hline & Klamath Upper Basin & $\begin{array}{l}\text { UKL tributaries, } \\
\text { Williamson } \\
\text { River }\end{array}$ & August & $\begin{array}{l}\text { Fortune, et al, } A \text { study to } \\
\text { Determine the Feasibility of } \\
\text { Establishing Salmon. }\end{array}$ \\
\hline & Klamath Upper Basin & UKL tributaries & Summer & $\begin{array}{l}\text { “New Dam Stops Fish in } \\
\text { Klamath," Mail Tribune, October } \\
26,1914 .\end{array}$ \\
\hline & Klamath Upper Basin & $\begin{array}{l}\text { UKL tributaries, } \\
\text { Chiloquin Area }\end{array}$ & Summer & $\begin{array}{l}\text { "Dr. McLean Will Go Fishing," } \\
\text { Morning Oregonian, July 12, } \\
\text { 1900, p 8; Brewster, William } \\
\text { Mead Ladd of Portlland Oregon }\end{array}$ \\
\hline \multirow[t]{5}{*}{ Fall } & IGD to Keno & Camp Creek & October 25, 1953 & $\begin{array}{l}\text { Coots, King Salmon Count - } \\
\text { Klamath River, Klamathon Racks }\end{array}$ \\
\hline & IGD to Keno & $\begin{array}{l}\text { Upper Klamath } \\
\text { River Canyon }\end{array}$ & Late Fall & $\begin{array}{l}\text { Theodoratatus, et al., Klamath } \\
\text { River Canyon Ethnology Study. }\end{array}$ \\
\hline & IGD to Keno & Jenny Creek & $\begin{array}{l}\text { October } 14 \text { to } \\
\text { November 3, } 1955\end{array}$ & $\begin{array}{l}\text { Hughes and Weber, Report on } \\
\text { North Coast Salmon Carcass } \\
\text { Recovery Work. }\end{array}$ \\
\hline & IGD to Keno & Jenny Creek & $\begin{array}{l}\text { October } 4 \text { and } \\
\text { October 6, } 1953\end{array}$ & $\begin{array}{l}\text { Coots, King Salmon Count - } \\
\text { Klamath River, Klamathon Racks }\end{array}$ \\
\hline & IGD to Keno & $\begin{array}{l}\text { Jenny Creek; } \\
\text { Old channel } \\
\text { below Copco } 2\end{array}$ & October 27, 1952 & $\begin{array}{l}\text { Coots and Wales, King Salmon } \\
\text { Activity in Jenny Creek }\end{array}$ \\
\hline
\end{tabular}

\begin{tabular}{|c|c|c|c|c|}
\hline SEASON & $\begin{array}{l}\text { WATERSHED } \\
\text { REFERENCE }\end{array}$ & LOCATION & DATE & SOURCE \\
\hline \multirow[t]{16}{*}{ Fall } & IGD to Keno & $\begin{array}{l}\text { Old channel } \\
\text { below Copco } 2\end{array}$ & October 22, 1953 & $\begin{array}{l}\text { Coots, King Salmon Count - } \\
\text { Klamath River, Klamathon Racks }\end{array}$ \\
\hline & IGD to Keno & $\begin{array}{l}\text { Copco } 2 \text { Dam } \\
\text { to Copco } 2 \\
\text { Powerhouse }\end{array}$ & $\begin{array}{l}\text { October } 16 \text { to } \\
\text { November } 3 \text {, } \\
1955\end{array}$ & $\begin{array}{l}\text { Hughes and Weber, Report on } \\
\text { North Coast Salmon Carcass } \\
\text { Recovery Work. }\end{array}$ \\
\hline & IGD to Keno & Fall Creek & $\begin{array}{l}\text { September } 7 \text { to } \\
\text { November 1, } 1953\end{array}$ & $\begin{array}{l}\text { Coots, King Salmon Count - } \\
\text { Klamath River, Klamathon Racks }\end{array}$ \\
\hline & IGD to Keno & Fall Creek & $\begin{array}{l}\text { As early as } \\
\text { September } 9\end{array}$ & $\begin{array}{l}\text { Wales and Coots, "Efficiency of } \\
\text { Chinook Salmon Spawning in } \\
\text { Fall Creek, California," 137-49. }\end{array}$ \\
\hline & IGD to Keno & Fall Creek & $\begin{array}{l}\text { September } 9 \text { to } \\
\text { October } 28,1954\end{array}$ & $\begin{array}{l}\text { Coots, Efficiency of King Salmon } \\
\text { Spawning in Fall Creek, Siskiyou } \\
\text { County - Progress Report for } \\
1953-54 .\end{array}$ \\
\hline & IGD to Keno & Fall Creek & $\begin{array}{l}\text { September } 20 \text { to } \\
\text { October } 25,1954\end{array}$ & $\begin{array}{l}\text { Coots, Klamath River } 1954 \text { King } \\
\text { Salmon Count }\end{array}$ \\
\hline & IGD to Keno & Fall Creek & $\begin{array}{l}\text { September } 25 \text { to } \\
\text { November } 6\end{array}$ & $\begin{array}{l}\text { Wales, Management of King } \\
\text { salmon spawning in the } \\
\text { Klamath River }\end{array}$ \\
\hline & IGD to Keno & Fall Creek & October & $\begin{array}{l}\text { Wright, "George Wright's } \\
\text { Transcripted Diary-Origin of } \\
\text { the Place Names of Southern } \\
\text { Oregon and Northern California } \\
\text { with History from Late 1800s to } \\
\text { 1950s." }\end{array}$ \\
\hline & IGD to Keno & Shovel Creek & $\begin{array}{l}\text { Early September } \\
\text { to October }\end{array}$ & $\begin{array}{l}\text { Steele, "The Big One up Shovel } \\
\text { Creek." }\end{array}$ \\
\hline & IGD to Keno & Shovel Creek & $\begin{array}{l}\text { September } 1 \text { to } \\
\text { November } 1\end{array}$ & $\begin{array}{l}\text { "Where Shovel Creek Reaches } \\
\text { the Klamath," San Francisco } \\
\text { Call, June 27, 1909. }\end{array}$ \\
\hline & IGD to Keno & Shovel Creek & Fall & $\begin{array}{l}\text { "Crippled Fisherman Handy with } \\
\text { the Rod," San Francisco Call, } \\
\text { September 24, 1911. }\end{array}$ \\
\hline & IGD to Keno & Spencer Creek & $\begin{array}{l}\text { September and } \\
\text { October }\end{array}$ & $\begin{array}{l}\text { U.S. Department of Interior, } \\
\text { et. al, Spencer Creek Pilot } \\
\text { Watershed Analysis, } 1995 .\end{array}$ \\
\hline & IGD to Keno & Spencer Creek & Fall & $\begin{array}{l}\text { High, History of Alice Isobell } \\
\text { Spencer High, of Ashland. }\end{array}$ \\
\hline & IGD to Keno & Keno & $\begin{array}{l}\text { September 10, } \\
1908\end{array}$ & $\begin{array}{l}\text { Fortune, et. al, } A \text { study to } \\
\text { Determine the Feasibility } \\
\text { of Establishing Salmon and } \\
\text { Steelhead in the Upper Klamath } \\
\text { Basin. }\end{array}$ \\
\hline & IGD to Keno & Keno & $\begin{array}{l}\text { September 16, } \\
1909\end{array}$ & $\begin{array}{l}\text { "Keno Items," Klamath } \\
\text { Republican, September 16, } 1909 .\end{array}$ \\
\hline & IGD to Keno & Keno & $\begin{array}{l}\text { September } 24, \\
1908\end{array}$ & $\begin{array}{l}\text { "Millions of Salmon," Evening } \\
\text { Herald, September 24, } 1908 .\end{array}$ \\
\hline
\end{tabular}




\begin{tabular}{|c|c|c|c|c|}
\hline SEASON & $\begin{array}{l}\text { WATERSHED } \\
\text { REFERENCE }\end{array}$ & LOCATION & DATE & SOURCE \\
\hline \multirow[t]{13}{*}{ Fall } & IGD to Keno & $\begin{array}{l}\text { Downstream } \\
\text { from Link River }\end{array}$ & $\begin{array}{l}\text { September 10, } \\
1903\end{array}$ & $\begin{array}{l}\text { "Local News - The Salmon } \\
\text { are Now Running," Klamath } \\
\text { Republican, September 10, } 1903 .\end{array}$ \\
\hline & Klamath Upper Basin & Link River & $\begin{array}{l}\text { August through } \\
\text { October }\end{array}$ & $\begin{array}{l}\text { Fortune, et. al, A study to } \\
\text { Determine the Feasibility } \\
\text { of Establishing Salmon and } \\
\text { Steel/head in the Upper Klamath } \\
\text { Basin. }\end{array}$ \\
\hline & Klamath Upper Basin & $\begin{array}{l}\text { Link River/ } \\
\text { Klamath Falls }\end{array}$ & $\begin{array}{l}\text { September } 18 \\
1902\end{array}$ & Ibid. \\
\hline & Klamath Upper Basin & $\begin{array}{l}\text { Link River/Lost } \\
\text { River }\end{array}$ & $\begin{array}{l}\text { September 20, } \\
1912 .\end{array}$ & $\begin{array}{l}\text { "Salmon Running in Rivers," } \\
\text { Morning Oregonian, September } \\
9,1912\end{array}$ \\
\hline & Klamath Upper Basin & $\begin{array}{l}\text { Link River and } \\
\text { downstream }\end{array}$ & Fall & $\begin{array}{l}\text { Shaver, et. al, Illustrated History } \\
\text { of Central Oregon. }\end{array}$ \\
\hline & Klamath Upper Basin & $\begin{array}{l}\text { Link River/ } \\
\text { Klamath Falls }\end{array}$ & Fall & $\begin{array}{l}\text { "Fish Laws Demanded," Morning } \\
\text { Oregonian, December 10, } 1910 .\end{array}$ \\
\hline & Klamath Upper Basin & $\begin{array}{l}\text { UKL tributaries, } \\
\text { Sprague River }\end{array}$ & $\begin{array}{l}\text { End of August and } \\
\text { September }\end{array}$ & $\begin{array}{l}\text { Lane and Lane Associates, The } \\
\text { Copco Dams and the Fisheries } \\
\text { of the Klamath Tribe. }\end{array}$ \\
\hline & Klamath Upper Basin & $\begin{array}{l}\text { UKL tributaries, } \\
\text { Sprague River }\end{array}$ & $\begin{array}{l}\text { End of August into } \\
\text { October }\end{array}$ & Ibid. \\
\hline & Klamath Upper Basin & $\begin{array}{l}\text { UKL tributaries, } \\
\text { Sprague River }\end{array}$ & $\begin{array}{l}\text { End of August into } \\
\text { October }\end{array}$ & Ibid. \\
\hline & Klamath Upper Basin & $\begin{array}{l}\text { UKL tributaries, } \\
\text { Sprague River }\end{array}$ & September & $\begin{array}{l}\text { Dice Crane, } 1946, \text { in Courtright } \\
\text { and Simmons, Affidavits } \\
\text { 1941-1946, NARA Pacific Alaska } \\
\text { Region. }\end{array}$ \\
\hline & Klamath Upper Basin & $\begin{array}{l}\text { UKL tributaries, } \\
\text { North Fork } \\
\text { Sprague River }\end{array}$ & $\begin{array}{l}\text { Late September/ } \\
\text { arly October }\end{array}$ & $\begin{array}{l}\text { Carrie Schmitz, 1946, in } \\
\text { Courtright and Simmons, } \\
\text { Affidavits 1941-1946, NARA } \\
\text { Pacific Alaska Region. }\end{array}$ \\
\hline & Klamath Upper Basin & $\begin{array}{l}\text { UKL tributaries, } \\
\text { Sprague River }\end{array}$ & $\begin{array}{l}\text { Last part of } \\
\text { September }\end{array}$ & $\begin{array}{l}\text { Frank Obenchain, 1946, in } \\
\text { Courtright and Simmons, } \\
\text { Affidavits 1941-1946, NARA } \\
\text { Pacific Alaska Region. }\end{array}$ \\
\hline & Klamath Upper Basin & $\begin{array}{l}\text { UKL tributaries, } \\
\text { Williamson and } \\
\text { Sprague rivers }\end{array}$ & $\begin{array}{l}\text { September and } \\
\text { October }\end{array}$ & $\begin{array}{l}\text { H. Gullickson, "Memorandum } \\
\text { to the Commissioner of Indian } \\
\text { Affairs: Report covering } \\
\text { recommended damages in } \\
\text { the proposed suit against } \\
\text { the California-Oregon Power } \\
\text { Company, resulting from the } \\
\text { destruction of Indian fisheries } \\
\text { on the Klamath River," U.S. } \\
\text { Department of the Interior, } \\
\text { Office of Indian Affairs, Billings, } \\
\text { Montana, 1946; NARA Pacific } \\
\text { Alaska Region. }\end{array}$ \\
\hline
\end{tabular}

\begin{tabular}{|c|c|c|c|c|}
\hline SEASON & $\begin{array}{l}\text { WATERSHED } \\
\text { REFERENCE }\end{array}$ & LOCATION & DATE & SOURCE \\
\hline \multirow[t]{13}{*}{ Fall } & Klamath Upper Basin & $\begin{array}{l}\text { UKL tributaries, } \\
\text { Sprague River }\end{array}$ & $\begin{array}{l}\text { September and } \\
\text { October }\end{array}$ & $\begin{array}{l}\text { Delford Lang, 1946, in Courtright } \\
\text { and Simmons Affidavits } \\
\text { 1941-1946, NARA Pacific Alaska } \\
\text { Region. }\end{array}$ \\
\hline & Klamath Upper Basin & $\begin{array}{l}\text { UKL tributaries, } \\
\text { Sprague River }\end{array}$ & $\begin{array}{l}\text { September and } \\
\text { October }\end{array}$ & $\begin{array}{l}\text { Simmons, Proposed Action for } \\
\text { Injunction and Damages: United } \\
\text { States vs California Oregon } \\
\text { Power Company. Washington, } \\
\text { D.C.: United States, } 1942 .\end{array}$ \\
\hline & Klamath Upper Basin & \begin{tabular}{|l} 
UKL tributaries, \\
Sprague River \\
(Cottonwood \\
Springs)
\end{tabular} & $\begin{array}{l}\text { September and } \\
\text { October }\end{array}$ & $\begin{array}{l}\text { Watson Duffy, 1946, in Courtright } \\
\text { and Simmons Affidavits } \\
\text { 1941-1946, NARA Pacific Alaska } \\
\text { Region. }\end{array}$ \\
\hline & Klamath Upper Basin & UKL tributaries & October 6, 1911 & $\begin{array}{l}\text { Fortune, et. al, A study to } \\
\text { Determine the Feasibility } \\
\text { of Establishing Salmon and } \\
\text { Steel/head in the Upper Klamath } \\
\text { Basin. }\end{array}$ \\
\hline & Klamath Upper Basin & $\begin{array}{l}\text { UKL tributaries, } \\
\text { Klamath } \\
\text { Agency }\end{array}$ & $\begin{array}{l}\text { Around October } \\
\text { 7, } 1886\end{array}$ & $\begin{array}{l}\text { Correspondence (1886) between } \\
\text { J. Merrill and G. Brown Goode } \\
\text { and S.F. Baird from Ft. Klamath, } \\
\text { Oregon, Record Unit 305, Acces- } \\
\text { sion no. . } 9748 \text {, Smithsonian Inst- }- \text {, Washing } \\
\text { tution Archives, Washington, D.C. }\end{array}$ \\
\hline & Klamath Upper Basin & $\begin{array}{l}\text { UKL tributaries, } \\
\text { Sprague River }\end{array}$ & October 10, 1901 & $\begin{array}{l}\text { "The Twentieth Century - First } \\
\text { salmon of the season..." Lake } \\
\text { County Examiner, October 10, } \\
\text { 1901. }\end{array}$ \\
\hline & Klamath Upper Basin & $\begin{array}{l}\text { UKL tributaries, } \\
\text { UKL }\end{array}$ & October 10, 1890 & $\begin{array}{l}\text { "Pacific Coast News," Sausalito } \\
\text { News, October 10, } 1890 .\end{array}$ \\
\hline & Klamath Upper Basin & $\begin{array}{l}\text { UKL tributaries } \\
\text { Sprague River/ }\end{array}$ & October 12, 1911 & $\begin{array}{l}\text { "Some salmon were brought } \\
\text { into town..." Lake County } \\
\text { Examiner, October 12, } 1911 .\end{array}$ \\
\hline & Klamath Upper Basin & UKL tributaries & October 14, 1909 & $\begin{array}{l}\text { "Great Sport on the River," } \\
\text { Klamath Republican, October } \\
\text { 14, 1909. }\end{array}$ \\
\hline & Klamath Upper Basin & $\begin{array}{l}\text { UKL tributaries, } \\
\text { Sprague River }\end{array}$ & October 19, 1911 & $\begin{array}{l}\text { "Charlie Baker, one of the } \\
\text { Klamath Indians..." Lake } \\
\text { County Examiner, October 19, } \\
\text { 1911. }\end{array}$ \\
\hline & Klamath Upper Basin & UKL tributaries & October & $\begin{array}{l}\text { H. Wilson, Handwritten report on } \\
\text { salmon fishing on the Klamath } \\
\text { Indian Reservation, 1916, in } \\
\text { 1915-Klamath Agency-115, Record } \\
\text { Group 75, Central Classified } \\
\text { Files, 1907-1939, NARA. }\end{array}$ \\
\hline & Klamath Upper Basin & UKL tributaries & November 3 & $\begin{array}{l}\text { "Indians Oppose Salmon Racks } \\
\text { at Hatcheries," Klamath Evening } \\
\text { Herald, November } 3,1913 .\end{array}$ \\
\hline & Klamath Upper Basin & UKL tributaries & Fall & Spier, Klamath Ethnography. \\
\hline
\end{tabular}




\begin{tabular}{|c|l|l|l|l|}
\hline SEASON & $\begin{array}{r}\text { WATERSHED } \\
\text { REFERENCE }\end{array}$ & LOCATION & \multicolumn{1}{|c|}{ DATE } & \multicolumn{1}{c|}{ SOURCE } \\
\hline \multirow{2}{*}{ Fall } & Klamath Upper Basin & UKL tributaries & $\begin{array}{l}\text { Fall (2 runs "noted } \\
\text { even to the } \\
\text { headwaters") }\end{array}$ & $\begin{array}{l}\text { Snyder, Salmon of the Klamath } \\
\text { River California. }\end{array}$ \\
\cline { 2 - 5 } & Klamath Upper Basin & UKL tributaries & Fall & $\begin{array}{l}\text { "New Dam Stops Fish in } \\
\text { Klamath," Medford Tribune, } \\
\text { October 26, 1914. }\end{array}$ \\
\cline { 2 - 5 } & Klamath Upper Basin & UKL tributaries & $\begin{array}{l}\text { Later part of } \\
\text { November }\end{array}$ & $\begin{array}{l}\text { Gatschet, The Klamath Indians } \\
\text { of Southwestern Oregon, 30. }\end{array}$ \\
\hline
\end{tabular}

\section{NOTES}

The findings and conclusions in this article are Pess; Laura Pickard Grabner; Scott Snedaker; those of the authors and do not necessarily David K. White; Plumy Wright; the Klamath life Service, National Marine Fisheries Service, Museum; the Klamath County Library; Jules U.S. Geological Survey, the Klamath Tribes, or Filipski of the Oregon Historical Society; the Oregon Department of Fish and Wildlife. Southern Oregon University Hannon Library Previous reports have summarized infor- Oregon State University, Gerald D. Williams mation on some of the aspects of historical Collection; Anne Hiller Clark, Barbara Ditpopulations of Chinook salmon upstream from man, Kelly Peterson, and Alla Powers of Shaw the dams on the Klamath River. For this, we Historical and the Oregon Institute of Technolare indebted to Millard Coots, Douglas Deur, ogy Libraries; Marene Baker, Peter Brauer, John Fortune and co-authors, E Richard Hart Ken House, Mary Francis Ronan, and Joseph John For

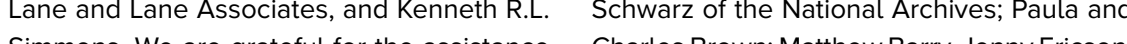
Simmons. We are grateful Charles Brown; Matthew Barry, Jenny Ericson, of many others who provided constructive and John Fisher, Ron Larson, Joe Polos, Anne Post, helpful comments, information, reviews, and/ and Nicholas Som of the U.S. Fish and Wildlife or contributions to our work - Linda Bagley; Service; the San Francisco Public Library; the David Banks; Rae Benson; Greg Bryant; Bob University of California Bancroft Library; the Busby; Jerry Curry; Gary Curtis; Oregon State Smithsonian Institution Archives; the California University Library; Larry Dunsmoor; Martin State Library; the California State Archives; Flogerzi; Mary Gentry; Mark Hampton; David the Siskiyou County Museum and Historical Harder; Chuck Huntington; Dennis Lynch, Society; and the Klamath Tribes.

U.S. Geological Survey; Joanne Mack: Kim 1. L. Spier Klamath Ethnography (BerkeMattson; Bill McMillan; Marshal Moser; George $\quad$ ley: University of California Press, 1930); L.
Cressman, W. Haag, and W. Laughlin, "Klamath Management Council," March 6-7, 2005, Prehistory: The prehisto Klamath Lake Area, Oregon," Trons of the American Philosophical Society 46.4 (1956): 375-513.

2. D. Deur, Final Report - Traditional Cultural Properties and Sensitive Resource Study: Klamath Hydroelectric Project FERC relicensing documentation, Report to the Klamath Tribes, 2003.

3. F.A. Shaver, Arthur P. Rose, Richard F. Steele, A.E. Adams, Illustrated History of Central Oregon Embracing Wasco, Sherman, Gilliam, Wheeler, Crook, Lake, and Klamath Counties - State of Oregon (Spokane, Wash: Western Historical Publishing Company, 1905). 989-90.

D. Deur "The Klamath Tribes: Restoring Peoples, Restoring Ties to the Land," The Firs Oregonians, Laura Berg, ed. (Portland: Oregon Council for the Humanities, 2007).

5. J. Hamilton, G. Curtis, S. Snedaker, and D. White, "Distribution of Anadromous Fishes in the upper Klamath River Watershed Prior to Hydropower Dams - a Synthis of the tisHydropow Das 6 . Eart Leitritz, A History of Californiq's

6. Earh Leith, A History of Calfonia's Fish Haccheries 1870-1960, Fish Bulletin 150 California Department of Fish and Game, Inland Fisheries Branch, 1970; S. Powers, Tribes of California (Berkeley, California: University of California Press, 1877); Jeffrey LaLande, First Over the Siskiyous: Peter Skene Ogden's 1826 - 1827 Journey Through the Oregon-California Borderlands (Portland: Oregon Historical Society Press, 1987): 6 Hewes. "Aboriginaluse of in Northwestern North America," (Ph.D. diss.,
University of California, 1947).

7. Moyle P., Inland Fishes of California $2 d$ ed (Berkeley and Los Angeles: University of California Press, 2002), 258.

8. Klamath Fisheries Management Council, "Final Minutes Klamath Fisheries Management Council," March 8-12, 2004 Tacoma, Washington, www.fws gov/yreka/ KFMC-Min/03-08-04.pdf (accessed March 16, 2016); Klamath Fisheries Management Council, "Final Minutes Klamath Fisheries Sacramento, California, www.fws.gov/yreka/ KFMC-Min/03-06-05.pdf (accessed March 17. 2016): Klamath Fisheries Management Council "Final Minutes Klamath Fisheries Management Council, February 21-23, 2006, Eureka, California, www.fws.gov/yreka/KFMCMin/02-21-06.pdf (accessed March 17, 2016). 9. U.S. Department of the Interior, California Department of Fish and Game, Klamath Facilities Removal Final Environmental Impact Statement/Environmental Impact Report, Volume I sections 1 and 38. US. Department of the Interior, Bureau of Reclamation me Sacramento California December

10. Bob Hooton and Roger Smith, A Plan for the Reintroduction of Anadromous Fish in the Upper Klamath Basin, Oregon Department of Fish and Wildlife, 200; Charles W. Huntingon, Errol W. Claire, F. Al Espinosa, Jr., Robert House, Reintroduction of Anadromous Fish to the Upper Klamath Basin: An Evaluation and Conceptual Plan, prepared for the Klamath and Yurok Tribes, March 2006.

11. John Charles Frémont, Narratives of Exploration and Adventure (New York: Longmans, Green, and Co., 1956); Lewis Publishing, A Memorial and Biographical History of Northern California (Chicago: Lewis Publishing, 1891).

12. U.S. Department of the Interior and U.S. Department of Commerce, National Marine Fisheries Service, Klamath Dam Removal Interior: An Assessment of Science and TechMoyle, Inland Fishes of California, (Berkeley: University of California Press, 2002), 258-59.

13. Klamath River Basin Fisheries Task Force, Long Range Plan for the Klamath River Basin Conservation Area Fishery Restoration Program, prepared with the assistance of William M. Kier Associates, U.S. Fish and Wildlife Service, Yreka, California, January 1991, 99-552.

14. James W. Moffett and Stanford E. Smith, Biological Investigations of the Fishery Resources of the Trinity River, California, Overview Report for the Secretary of the 
Special Scientific Report, Fisheries No. 12 (Washington, D.C.: U.S. Department of the Interior, Fish and Wildlife Service; 1950); U.S. Department of the Interior. Klamath River Basin Fisheries Resource Plan, prepared by $\mathrm{CH}_{2} \mathrm{M}$ Hill, U.S. Department of the Interio Yreka, California, 1985

15. Joaquin Miller, Life Amongst the American Publishing Co., 1873).

16. Klamath River Basin Fisheries Task Force, Long Range Plan for the Klamath River Basin, 99-552; Moffett and Smith, Biological Investigations of the Fishery Resources of the Trinity River.

17. U.S. Department of the Interior and California Department of Fish and Game (CDFG), Klamath Facilities Removal Final Environmental Impact Statement/Environmental Impact Report, Volume III - Comments and Responses, Section 11.9, Individuals, Sacramento, California, 2012, https://klamathrestoration.gov/sites/klamathrestoration.gov/ files/Additonal\%20Files\%20/1/4/Volume\%20 IIIIndividuatpdf (accessed August 16, 2016).

18. John O. Snyder, Salmon of the Klamath River California. Division of Fish and Game of California, Fish Bulletin no. 34, January 1931

19. Klamath River Basin Fisheries Task Force, Long Range Plan for the Klamath River Basin, 99-552.

20. Brett Towler, Alex Hoar, and David Ahlfeld, "Ecohydrology and Fish-Passage Engineering: Legacy of Denil and the Call for a More Inclusive Paradigm," Journal of Water Resources Planning and Management 138: (March/April 2012): 77-79.

21. Meriwether Lewis and William Clark, August 13, 1805, entry in the Journals of the Lewis and Clark Expedition, ed. Gary Moulton (Lincoln, Neb.: University of Nebraska Press/ University of Nebraska-Lincoln Libraries-Electronic Text Center, 2005) http://lewisandclarkjournals.unl.edu/read?_xmlsrc=1805-08-13.xm (accessed March 14, 2016).

22. LaLande, First Over the Siskiyous.

23. Frémont, Narratives of Exploration and Adventure.

24. Hamilton, Curtis, Snedaker, and White
"Distribution of Anadromous Fishes," 10-20; Lane and Lane Associates, The Copco Dams and the Fisheries of the Klamath Tribe, prepared for the Bureau of Indian Affairs, US. Department of the Interior, Portland, Oregon, 1981. 25. "Fish Laws Demanded," Morning Oregonian, December 10, 1910, p. 3.

26. "Inspect the Klamath Dam - Officials will Investigate Salmon Shortage," Klamath Evening Herald, October 28, 1913; "Indians Oppose Salmon Racks at Hatcheries - Future Supply in Serious Danger," Klamath Evening Herald, November 3, 1913, P. 1; "May Ask US. to See that River is Kept Clear: Is Shutting off Indians Salmon Supply." Klamath Evening Herald, October 23, 1914.

27. Kenneth R.L. Simmons, Proposed Action for Injunction and Damages: United States v. California Oregon Power Company. Washington, D.C.: United States, 1942.

28. Correspondence (1886) between J.C. Merrill and G. Brown Goode and S.F. Baird from Ft. Klamath, Oregon, Record Unit 305 Accession no. 19748, Smithsonian Institution Archives, Washington, D.C.

29. Virginia Butler, Alexander E. Stevenson, Jessica A. Miller, Donbya Y. Yang, Camilla F. Speller, and Nicole Misarti, The Use of Archaeological Fish Remains to Establish Pre-development Salmonid Biogeography in the Upper Klamath Basin, Final Report, Portland State University, 2010; Alexander E. Stevenson, "Using Archaeological Fish Remains to Determine the Native Status of Anadromous Salmonids in the Upper Klamath Basin (Oregon, USA) through mtDNA and Geochemical Analysis" (M.S. thesis, Portland State University, 2011)

30. Lane and Lane Associates, The Copco Dams and the Fisheries of the Klamath Tribe; Simmons, Proposed Action for Injunction and Damages.

31. Hewes, "Aboriginal Use of Fishery Rources in Northwestern North America." 32. Leitritz, A History of California's Fish Hatcheries.

33. Powers S. Tribes of California (Berkeley: University of California Press, 1877).

34. K.R.L. Simmons, District Counsel, U.S.
Department of the Interior, Office of Indian Affairs, Field Service to Matt Ryckman, Oregon Superintendent of Fisheries, 1941, in Bureau of Superintendent of Fisheries, 1941, in Bureau of Inflan Afars, Kla 75, Decimal Correspondence, box 109, Copco Case File, folders 1 and 3, National Archives and Records Administration, Pacific Alaska Region, Seattle, Washington [hereafter NARA Pacific Alaska Region].

35. Alfred L. Kroeber and S.A. Barrett, "Fishing Among the Indians of Northwestern California," in Anthropological Records, 21:1 Fishing Among the Indians of Northwestern California, ed. J.H. Rowe, R.F. Heizer, R.F. Murphy, E. Norbeck (Berkeley and Los Angeles: University of California Publications, 1960): Alfred L. Kroeber. Handbook of the Indians of California (Berkeley: California Book Company, Ltd., 1953).

36. "Fish Ladder Needed," Oregonian, April 10, 1910.

37. "Inspect the Klamath Dam - Officials will Investigate Salmon Shortage," Klamath Evening Herald, October 28, 1913; "Indians Oppose Salmon Racks at Halc "Indians Oppose Salm, Racks at Hatcheries - Future Supply in Serious Danger," "Flamath Evening Herald November, 1913 "Fish Ladder Needed," Oregonian, April 10 1910; "Millions of Salmon: Cannot Reach the Lake on Account of Rocks in River at Keno," Klamath Evening Herald, September 24 1908, p. 1; "Pacific Coast News: Incidents of the Week in Condensed Form - Salmon are now running up the Klamath River clear to lakes at its head. The dam at Klamath City was washed away last winter" Sausalito News, October 10, 1890 "Salmon Have Free Run Up the River," Yreka Journal, September 10, 1890; "The Fish Ladder at Pokegama" Yreka Journal, October 4, 1893.

8. LaLande, First Over the Siskiyous; Hewes, "Aboriginal Use of Fishery Resources", Oregon Department of Fisheries, Annual Report of the Department of Fisheries, State of Oregon, to the Legislative Assembly TwentyFirst Regular Session, Salem, 1901.

39. Oregon Department of Fisheries, Annual Report of the Department of Fisheries, 1901
40. Hewes, "Aboriginal Use of Fishery Resources."

41. LaLande, First Over the Siskiyous.

42. "Fish Laws Demanded," Morning Oregonian, December 10, 1910; "Fish Ladder Needed," Oregonian, April 10, 1910; "Millions of Salmon," Klamath Evening Herald, September 24, 1908; "Klamath River Salmon: Notification from Governor Pennoyer of their Destruction," Daily Union (Sacramento), September 25,1889

43. LaLande, First Over the Siskiyous: LaLande, "Through a Strange Country Covered with Lakes: Peter Skene Ogden and the Hudson's Bay Company in the Klamath Basin," Journal of the Shaw Historical Library 8:1 (1994): 1-28.

44. LaLande, "Through a Strange Couny," $1-28$.

45. LaLande, First Over the Siskiyous; aLande, "Through a Strange Country," 1-28.

46. Deur, Final Report - Traditional Cultural Properties and Sensitive Resource Study: Stevenson "Using Archaeological Fish Remains."

47. U.S. Department of the Interior and CDFG, Klamath Facilities Removal Final Environmental Impact Statement/Environmental mpact Report, Volume I, Section 3.11.3.5 Slope Stability/Landslides, Sacramento, California, December 2012.

48. Federal Energy Regulatory Commission, Opinion and Order for Petition to Require Licensee to Construct, Operate, and Maintain a Fish Hatchery Amending License and Directing Revised Filings, Opinion No 381 Issued March 14, 1963, Washington D.C. 1963 49. "Fish Being Slaughtered at Dam," Yreka Journal, September 25, 1889

50. "Klamath River Salmon: Notification from Governor Pennoyer of their Destruction," Daily Union (Sacramento), September 5,1889

51. "Salmon Killing Disgusting," Yreka urnal, October 2, 1889.

52. Daily Union (Sacramento), September 1889

53. "Fish Commissioner Named," Yreke Journal, October 9, 1889. 
54. "Klamath River Salmon: Notification from Governor Pennoyer of their Destruction Daily Union (Sacramento),September 25, 1889; "The Pacific Coast: Seven men have been arrested for violating the salmon law. . . " Union Oregon Scout, October 171889.

55. Yreka Journal, September 10, 1890.

56. "The Fish Ladder at Pokegama,

Yreka Journal, October 4, 1893; California State Board of Fish Commissioners, Biennial Report for the Years 1891-1892 (Sacramento: State of California, 1892): "On the Klamath: An Obstruction that Has Been Removed" San Francisco Call, February 19 1893; "The Angler", San Francisco Call, April 24, 1897.

57. F. Judah, "A Siskiyou vacation," West ern Field 1:5 (1902): 262-67.

58. "Incendiary's Torch Razes Entir Town," San Francisco Call, October 15, 1902.

59. "Fish Laws Demanded," Morning Oregonian, December 10, 1910

60. Ibid.; "Passed Legislature: New Senate Bills," Coos Bay Times, February 9, 1911, p. 4.

61. "Millions of Salmon," Klamath Evening Herald, September 24, 1908.

62. Deur, Final Report - Traditiona Cultural Properties and Sensitive Resource Study; Lane and Lane Associates, The Copco Dams and the Fisheries of the Klamath Tribe "May Ask U.S. to See that River is Kept Clear," Klamath Evening Herald, October 23, 1914; Simmons, Proposed Action for Injunction and Damages: United States vs California Oregon Power Company (Washington, D.C. United States, 1942). See also Table 2.

63. "The Twentieth Century - First salmon of the season..." Lake County Examine October 10, 1901 "Some salmon were brough into town..." "Lake County Examine, Ocober 12, 1911; "Charlie Baker, one of the Klamath Indians ... " Lake County Examiner, October 19 1911; "Indian fishers sell fine wares," Klamath Evening Herald, October 15, 1911; G. Duncan, "Klamath Falls to Pokegama by the Old Stage and Freight Stations," Yearbook 1948, Siskiyou County Historical Society 1:3 (1948), 45: W. mary of biogra held at the Siskiy Historica Society Yeka, Calforna Alce Hes- sig, "The History of Klamath Hot Springs," The Siskiyou Pioneer in Folklore, Fact, and Fiction and Yearbook 3:8 (1965): 63-69; Hessig, Looking Back: The California-Oregon Stage Road from Ager, California to Topsy, Oregon (Carson City, Nev.: Printers, Inc., 1979).

64. Hessig, Looking Back; Hessig, "The History of Klamath Hot Springs," Siskiyou Pioneer 3:8 (1965): 63-69.

65. Klamath Hotsprings Resort, Siskiyou, California, Advertisement, Sunset Magazine, [August] 1911; Stephen Dow Beckham, Historical Landscape Overview of the Upper Klamath River Canyon of Oregon and California Culurat Resource Series no. 13 US. Department of the Interior, Burea of Land Management, Portland, Oregon, 2006.

66. Beckham, Historical Landscape Overview of the Upper Klamath River Canyon; Al M. Cumming and Allan Dunn, "The Klamath Region," California for the Sportsman: Southern Pacific (San Francisco: Southern Pacific Company, 1911): 20-26.

67. "Fish and Game Haunts Along the State's Backbone" San Francisco Coll [June 18], 1911.

68 ."The Fisherman's Vacation," San Francisco Call, July 24, 1904; "Where Shovel Creek Reaches the Klamath: the Famous Fishing and Hunting Ground of Northern California," San Francisco Call, June 27, 1909; "Crippled Fisherman Handy with the Rod," San Francisco Call, September 24, 1911; "Photo - J. Bernard Frisbee of Berkeley with a limit of rainbow trout at Klamath Hot Springs," San Francisco Call, August 29, 1912: Judah " "A Siskiyou vacation," 262-267; Rufus Steele, "The Big One up Shovel Creek," Western Field (October 1909): 49-56; Al Cumming, "Angling on the Klamath," Sunset ([April ] 1907), 577-83.

9. Judah, "A Siskiyou vacation," 262-67.

70. John C. Boyle, 50 Years on the Klamath (Medford, Oregon: Klocker Printery, 1976); Devere Helfrich, ed., "Keno and Vicinity," Klamath Echoes, no. 7 (1969): 47-50.

$$
\text { 71. U.S. Department of the Interior, Bureau }
$$

of Land Management, US. Department of Agriculture, Protection Agency, and U.S. Department of the Interior, Fish and Wildlife Service, Spencer Creek Pilot Watershed Analysis, Klamath Field Office, Klamath Falls, Oregon, 1995.

72. Klamath Echoes, Stagecoach to Linkville Issue no. 11 (1973), 14.

73. "Fish Ladder Needed," Oregonian, April 10, 1910; Salem Daily Capitol Journa (1910).

74. Philip Williams and Associates, A River Once More: Restoring the Klamath River Following Removal of the Iron Gate, Copco, and J. C. Boyle Dams, prepared for the California State Coastal Conservancy, 2009

75. Helfrich, ed., "Keno and Vicinity," 47-50.

76. Floyd Wynne, "Link River," Klamath Echoes 1:4 (1967): 15-16.

77. Deur Final Report - Traditional Cultural Properties and Sensitive Resource Study; Fortune, Gerlach, and Hanel, A study to Determine the Feasibility of Establishing Salmon; Wynne, "Link River," 15-16; Good, History of Klamath County Oregon: Frain "As Told to Me," 7-8; Spindor, Yulalona: A Report on Link River, Helfrich, ed., "Keno and Vicinity," Klamath Echoes, no. 7 (1969): 47-50.

78. Hamilton, Curtis, Snedaker, and White "Distribution of Anadromous Fishes in the upper Klamath River," 10-20; Wynne, "Link River," 15-16; George Masten Miller, "As Told to Me" recorded by Devere Helffrich, February 28 , 1948, Klamath Echoes No. 1, Early Klamath County History Issue (1964): 13-17; Devere Helfrich, "The First Boats," Klamath Echoes, No. 2, Klamath County Boats Issue (1965).

79. Frain, "As Told to Me," 7-8. For a discussion of Maude Baldwin's photographs of salmon fishing at Link River, see Hamilton et al. "Distribution of Anadromous Fishes in the upper Klamath River," 14-15.

8. Simmons, Proposed Action for Injunction and Damages; Klamath Echoes, no. Sprague River Valley Issue (1974): 75-76.

81. Simmons, Proposed Action for Injunction and Damages.

82. M. Flogerzi to John Hamilton, email correspondence regarding the Chiloquin Bridge, March 17, 2014, Chiloquin, Oregon.

83. B. Courtright to Kenneth R.L. Simmons, letter, August 13, 1941, in Bureau of Indian Decimal Corresponc " files NARA Pacific Alaska Region.

84. B. Courtright and K. Simmons, Affidavits 1941-1946 regarding historical salmon fishery upstream from Copco 1 Dam, U.S. Department of the Interior, Office of Indian of Indian Affairs, Klamath Agency, Record Group 75, Decimal Correspondence, box 109, Copco Case File, folders 1 and 3. U.S. Department of the Interior Office of Indian Affairs [hereafter Courtight Ond Sim NARA Pacific Alaska Region. Cited here NARA Pacific Alaska Region. Cited here are 85. Earl F. Moore, Western Echoes (Klamath Falls, Ore.: Paul Tremaine Publis ing, 1981)

86. B. Courtright, "Memorandum - Salmon on the Klamath," January 16, 1941, Bureau of Indian Affairs, Klamath Agency, Record Group 75, Decimal Correspondence, file 3 of 3 of fles titled, " 419.4 COPCO Case, 1940-1946," NARA Seattle.

87. Simmons, Proposed Action for Injunction and Damages: "The Twentieth Century -First salmon of the season. .. ." Lake County Examiner, October 10, 1901; "Some salmo were brought into town..." Lake County Examiner, October 12, 1911; "Charlie Baker, one of the Klamath Indians..." Lake County Examiner, October 19, 1911; "Indian fishers sell fine wares," Klamath Evening Herald, October 15, 1911.

88. Albert Samuel Gatschet, The Klamath Indians of Southwestern Oregon (Washing-

ton, D.C. U.S. Government Printing Office, 1890), 711

89. C. Groot and L. Margolis, eds., Pacific

Salmon - Llfe Histories (Vancouver: University

of British Columbia Press, 1991), 314.

90. Affidavit of Watson Duffy, August 18, 1946, Courtright and Simmons Affidavits 1941-1946, NARA Pacific Alaska Region.

91. Snyder, Salmon of the Klamath River California.

92 Simmons to Matt Ryckman, 1941, NARA Pacific Alaska Region. 
93. Leitritz, A History of California's Fish Hatcheries 1870-1960; Lane and Lane Associates, The Copco Dams and the Fisheries of the Klamath Tribe.

94. Klamath River Basin Fisheries Task Force, Long Range Plan for the Klamath Rive Basin, 99-552; Snyder, Salmon of the Klamat River California; California Fish and Game Commission, Twenty-Fifth Biennial Report: For the years 1916-1918; Shebley to Meritt, letter January 21, 1916, NARA Pacific Alaska Region.

95. H. Smith, Commissioner of Bureau Fisheries to E.B. Meritt, report, March 17, 1916 in 2446-1915-Klamath Agency-115, Record Group 75, Central Classified Files, 1907-1939, NationalArchives and Records Administration, Washington, D.C. [hereafter NARA].

96. "Some salmon were brought into town. .. " Lake County Examiner, October 12 1911; "Charlie Baker, one of the Klamath Indians..." Lake County Examiner, October 19 1911; “ "Indian fishers sell fine wares," Klamat Evening Herald, October 15, 1911.

97. John Hamilton, Dennis Rondorf and C. Ellsworth, Williams on River Water Temperature Survey - Note to Klamath River Secretarial Determination Files, U.S. Fish and Wildlife Service, Yreka Fish and Wildlife Office Yreka, California, August 27, 2010

98. D.V. Buchanan, A.R. Hemmingsen, D. Bottom, P.J. Howell, R.A. French, and K.P. Currens, Annual Progress Report Fish Research Project Oregon - Native Trout Project, Oregon Department of Fish and Wildlife, 1990.

99. Lane and Lane Associates, The Copco Dams and the Fisheries of the Klamath Tribe. 100. Moyle, Inland Fishes of California 259

101. J.M. Myers, P. Busby, S. Grant, R. Iwamoto, R. Kope, C. Mahnken, G. Matthews, P. Roni, M. Schiewe, D. Teel, T. Wainwright, F.W. Waknitz, R. Waples, J.G. Bryant, C. Wingert S. Lindley, P. Adams, A. Wertheimer, R. Re senbichler, Review of the Status of Chinook Salmon (Oncorhynchus tshawytscha) from Washington, Oregon, California, and Idaho under the U.S. Endangered Species Act, West
Coast Chinook Salmon Biological Review Team, 1997

102. Snyder, Salmon of the Klamath River California; Coots, Klamath River 1957 and 1958 King Salmon Counts; National Research Council, Hydrology, Ecology, and Fishes of the Klamath River Basin (Washington, D.C.: ational Academies Press, 2008).

103. Lane and Lane Associates, The Copco Dams and the Fisheries of the Klamath Tribe.

104. "Klamath Salmon Report Ready: Meeting Called for Tuesday," Herald and News (Klamath), September $25,1966,1 \mathrm{~A}$.

105. Lane and Lane Associates, The Copco Dams and the Fisheries of the Klamath Tribe, 147.

6. Simmons, Proposed Action for Injuncton and Damages.

107. "Inspect the Klamath Dam," Klamath Evening Herald, October 28, 1913

108. "Indians Oppose Salmon Racks," Klamath Evening Herald, November 3, 1913

109. "May Ask US, to See that River is Kept Clear" Klamath Evening Herald October 23, 1914.

110. Klamath River Basin Fisheries Task Force, Long Range Plan for the Klamath River Basin, 99-552; Snyder, Salmon of the Klamath River California; California Fish and Game Commission, Twenty-Fifth Biennial Report, 38; Shebley to Meritt, January 21, 1916, NARA. 111. "Some salmon were brought into town..." Lake County Examiner, October 12, 1911; "Charlie Baker, one of the Klamath " 19, 1911. 112. "Three big fish Stevens' Catch," . 113. "Salmon Running in Rivers," Morning regonian, September 9, 1912

114. Lane and Lane Associates, The Copco Dams and the Fisheries of the Klamath Tribes. 115. Our estimate of water velocity at full diversion in the tunnel was based on the following information. The unlined tunnel was 108.5 meters long with a cross sectional area of 4.9 meters by 5.5 meters and a grade of 2 percent. (See Boyle, 50 Years on the Klamath for specifics and a photo of the tunnel in 1911 during construction.) Water entered the tunnel through three headgates on three 1.8 meter through three headgates on three 1.8 meter
diameter, 9.1 meter length pipes secured in concrete to form a solid block to the tunnel entrance. The headgates and pipes were designed to carry the average flow of the river under a three meter head. Work on the headgates began in June 1912 and the first water was diverted through the headgates on October 12.1912. (See Sprout, Boyle, and Sprout Report of Work on Klamath River Report on the headgates, Project no. 1, 1912-1913.)

The minimum average daily flow measured during the years 1911 to 1913 was approximately 42.5 cubic meters per second (cms) and occurred in early fall of each year. (See Sprout, Boyle, Sprout, Report of Work on Klamath River, Project no. 1, 1913-1915.) Due to the lowest water velocities, this would have been when flows were most suitable for fish passage through the tunnel. We used Manning's equation for an open channel flow $42.5 \mathrm{cms}$, slope of 2.0 percent, a Maning's $42.5 \mathrm{cms}$, a slope of 2.0 percent a Manning's in of 0.05 for an excavated rock channel, and a cross sectional area of flow (constrained by the tunnel dimensions) of 4.9 meters by 5.5 meters to estimate water velocities in the tunnel. A conservative estimate of the velocity in the tunnel, assuming the pipes were completely full, would be approximately 3.3 meters per second (mps).

116. Milo Bell, "Swimming Speeds of Adult and Juvenile Fish," Fisheries Handbook of Engineering Requirements and Biological Criteria, Fish Passage Development and Evaluation Program, U.S. Army Corps of Engineers, North Pacific Division, Portland, Oregon, 1991. 117. Patrick D. Powers, John F. Orsborn, Analysis of Barriers to Upstream Fish Migration: An Investigation of the Physical and Biological Conditions Affecting Fish Passage Success at Culverts and Waterfalls, Report to Bonneville Power Administration, Portland, Oregon, 1985.
118. "New Dam Stops Fish in Klamath, Medford Tribune, October 26, 1914

119. Courtright and Simmons Affidavits 1941-1946, NARA Pacific Alaska Region.

120. P. McElhany, M. Rucklelshaus, M. Ford, T. Wainwright, and E. Bjorkstedt, Viable Salmonid Populations and the Recovery of Evolutionarily Significant Units. U.S. Department of Commerce, National Oceanic and Atmospheric Administration, National Marine Fisheries Service Technical Memorandum NMFS-NWFSC-42, June 2000

121. Daniel E. Schindler, Ray Hilborn, Brandon Chasco, C.P. Boatright, T.P. Quinn, L.A. Rogers, M.S. Webster, "Population Diversity and the Portfolio Effect in an Exploited Species, Nature (June 2010): 609-12; Daniel schindler, Jonathan Armstrong, Thomas E. Reed, "The Portfolio Concept in Ecology and Evolution, Frontiers in Ecology and Environment 13:5 (June 2015): 257-63; Correigh M. Greene, Jason E. Hall, Kimberly R. Guilbault, Thomas P. Quinn, "Improved Viability of Populations with Diverse Life-history Portfolios" Biology Letters 6:3 (June 2010): 382-86.

122. Schindler, Hilborn, Chasco, et al., "Population Diversity and the Portfolio Effect in an Exploited Species," 609-612; Jonathan W. Moore, Michelle McClure, Lauren A. Rogers and Daniel E. Schindler, "Synchronization and Portfolio Performance of Threatened Salmon," Conservation Letters 3:5 (September 2010): 1-9; Stephanie Marie Carlson and William Hallowell Satterthwaite, "Weakened Portfolio Effect in a Collapsed Salmon Population Complex" Canadian Journal of Fisheries and Aquatic Sciences 68:9 (2011): 1579-89.

123. R.S. Waples, T. Beechie, and G.R. Pess, "Evolutionary History, Habitat Disturbance Regimes, and Anthropogenic Changes: What do they Mean for Resilience of Pacific Salmon Populations?" Ecology 14:1 (November 2010): 3; Peter A. Bisson, Jason B. Dunham, Gordon H. Reeves, "Freshwater Ecosystems and Resilience of Pacific Salmon: Habitat Management Based on Natural Variability" Ecology and Society 14:1 (2009). 